\title{
The Long Site (41CE330), An Ancestral Caddo Site on Box's Creek in the Neches River Basin, Cherokee County, Texas
}

Timothy K. Perttula

Heritage Research Center, Stephen F. Austin State University

Kevin Stingley

Texas Archeological Stewardship Network, Texas Historical Commission

Follow this and additional works at: https://scholarworks.sfasu.edu/ita

Part of the American Material Culture Commons, Archaeological Anthropology Commons, Environmental Studies Commons, Other American Studies Commons, Other Arts and Humanities Commons, Other History of Art, Architecture, and Archaeology Commons, and the United States History Commons

Tell us how this article helped you.

This Article is brought to you for free and open access by the Center for Regional Heritage Research at SFA ScholarWorks. It has been accepted for inclusion in Index of Texas Archaeology: Open Access Gray Literature from the Lone Star State by an authorized editor of SFA ScholarWorks. For more information, please contact cdsscholarworks@sfasu.edu. 


\section{The Long Site (41CE330), An Ancestral Caddo Site on Box's Creek in the Neches River Basin, Cherokee County, Texas}

\section{Creative Commons License}

\section{(c) (1) \&}

This work is licensed under a Creative Commons Attribution-NonCommercial 4.0 International License 


\title{
The Long Site (41CE330), An Ancestral Caddo Site on Box's Creek in the Neches River Basin, Cherokee County, Texas
}

\author{
Timothy K. Perttula and Kevin Stingley
}

\section{Introduction and Site Setting}

The Long site is principally an ancestral Caddo site dating primarily to the Early Caddo period (ca. A.D. 900-1200), and the Alto phase, on Box's Creek in the Neches River basin in the East Texas Pineywoods (Figure 1). A few diagnostic decorated ceramic vessel sherds and radiocarbon dates also indicate that there is a Middle Caddo period (ca. A.D. 1200-1400) component there as well, along with a mid- $19^{\text {th }}$ century Anglo-American component on only one part of the site.

Box's Creek is a southeastern-flowing tributary of the Neches River, rising at the confluence of Bean's Creek and Dement Creek in south central Cherokee County. It runs ca. $26 \mathrm{~km}$ to its confluence with the Neches River, just west of the contemporaneous George C. Davis site (41CE19)/ Caddo Mounds State Historic Site, Newell and Krieger 1949, 2000; Story 1997, 1998, 2000); the Long site is about $10 \mathrm{~km}$ northwest of the George C. Davis site. The stream, intermittent in its upper course, flows through flat to gently rolling landforms with sandy loam soils (Mowery 1959) and the landscape has both hardwoods and pine trees (Diggs et al. 2006).

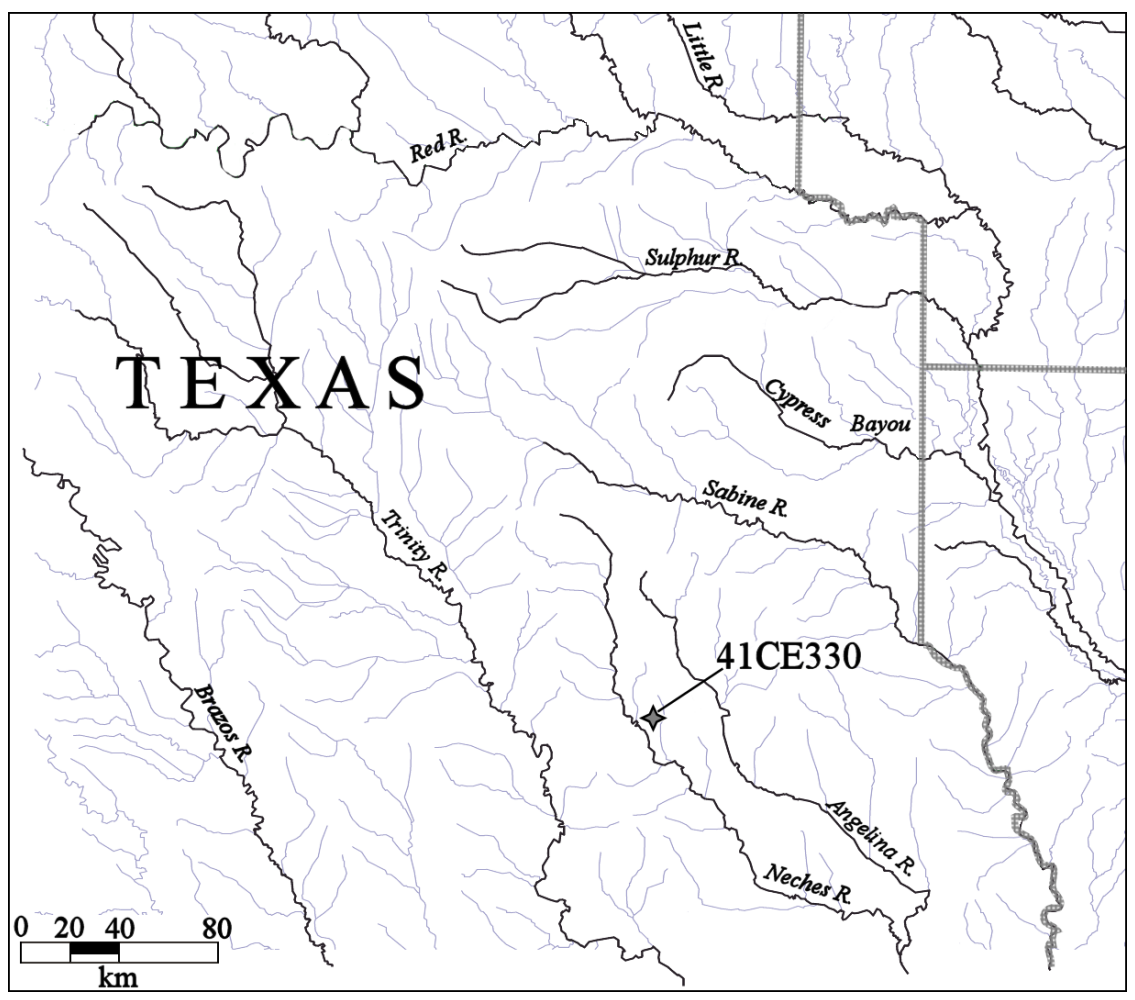

Figure 1. General location of the Long site (41CE330) in East Texas.

Journal of Northeast Texas Archaeology, Volume 84, 2020 
The site is on an alluvial terrace (270-280 feet amsl) landform about $125 \mathrm{~m}$ west of the channel of Box's Creek. The terrace has Hannahatchee fine sandy loam alluvial sediments (see Mowery 1959:22). According to Mowery (1959:22), this soil series "are moderately fertile and moderately to highly productive. They are usually the most fertile soils in the localities where they occur." A representative profile of the Hannahatchee fine sandy loam is reddish-brown to strong brown fine sandy loam A- to E-horizon deposits from $0-112 \mathrm{~cm}$ bs, underlain by light reddish-brown to strong brown clay. The fine sandy loam A- and E-horizon deposits at the Long site are not as thick as in the representative profile described by Mowery (1959), with the thickness of the fine sandy loam above the clay B-horizon ranging from ca. 15-80 cm, and most having B-horizons at depths of less than 60 cm bs (see Appendix 1).

\section{Previous Archaeological Investigations}

The Long site was recorded in 1997 during the course of an archaeological survey of a proposed utility line right-of-way (30-35 m in width) for the East Texas Electric Cooperative, Inc. SlocumAlto Segment in Anderson and Cherokee counties, Texas (Gearhart 1997). The site was found during shovel testing, with five shovel tests containing prehistoric and/or historic artifacts over a ca. 1500 square meter area $(0.37$ acres $)$ of the proposed right-of-way that occurred to depths between $0-20 \mathrm{~cm}$ bs for the historic artifacts (clear bottle glass sherds) and 10-90 cm bs for the prehistoric artifacts. The prehistoric artifacts from the shovel tests include chert, quartzite, and petrified wood lithic debris, a petrified wood core, fire-cracked rock, grog and bone-tempered plain and decorated ancestral Caddo ceramic vessel sherds, and an arrow point basal fragment (Gearhart 1997).

\section{8-2019 Archaeological Investigations}

Kevin Stingley, an East Texas Steward for the Texas Historical Commission and as the sole investigator, completed archaeological investigations at the Long site in February 2018, Januarymid-March 2019, and mid-March to mid-April 2019. Intensive shovel testing ( $n=136$, see Appendix 1) defined South and North sectors of the site, and Box's Creek is $125 \mathrm{~m}$ due east of the south sector (Figure 2). The creek is ca. 9-12 $\mathrm{m}$ wide, 1.8-2.4 $\mathrm{m}$ deep in places, with cut banks 3.0-4.6 m in height (Figure 3). There is a north-south fence that is the east property line and it marks the east boundary of both the North and South sectors. From the fence line at the eastern edge of the alluvial terrace proceeding east following the utility line right-of-way to Box's Creek, the elevation drops $4.6 \mathrm{~m}$ over a ca. $40 \mathrm{~m}$ slope down to the floodplain; from the floodplain to the creek channel is another $85 \mathrm{~m}$. The underground pipeline right-of-way ( $15 \mathrm{~m}$ in width) runs west to east to Box's Creek and crosses the creek going east. The utility line right-of-way runs parallel to the underground pipeline right-of-way.

Box's Creek does run along the north end of the site (see Figure 2), and ca. 5 m north of the North sector the elevation drops straight down $4.6 \mathrm{~m}$ to the creek (Figure 4). The alluvial terrace likely never floods. In the 2018 floods in the area, the water level in the creek floodplain reached halfway up the terrace cut bank, with water marks 1.2-1.5 $\mathrm{m}$ high on some trees close to the creek edge.

There is a small marsh just west of the South sector (Figure 5). It has standing water up to $10 \mathrm{~cm}$ in depth 10 months out of the year with marsh grass growing in it. It appears this area was the location of a large burn pile ca. 20 years ago when the utility line right-of-way was cleared. Ancestral Caddo sherds have also been found along the marsh's edge. 


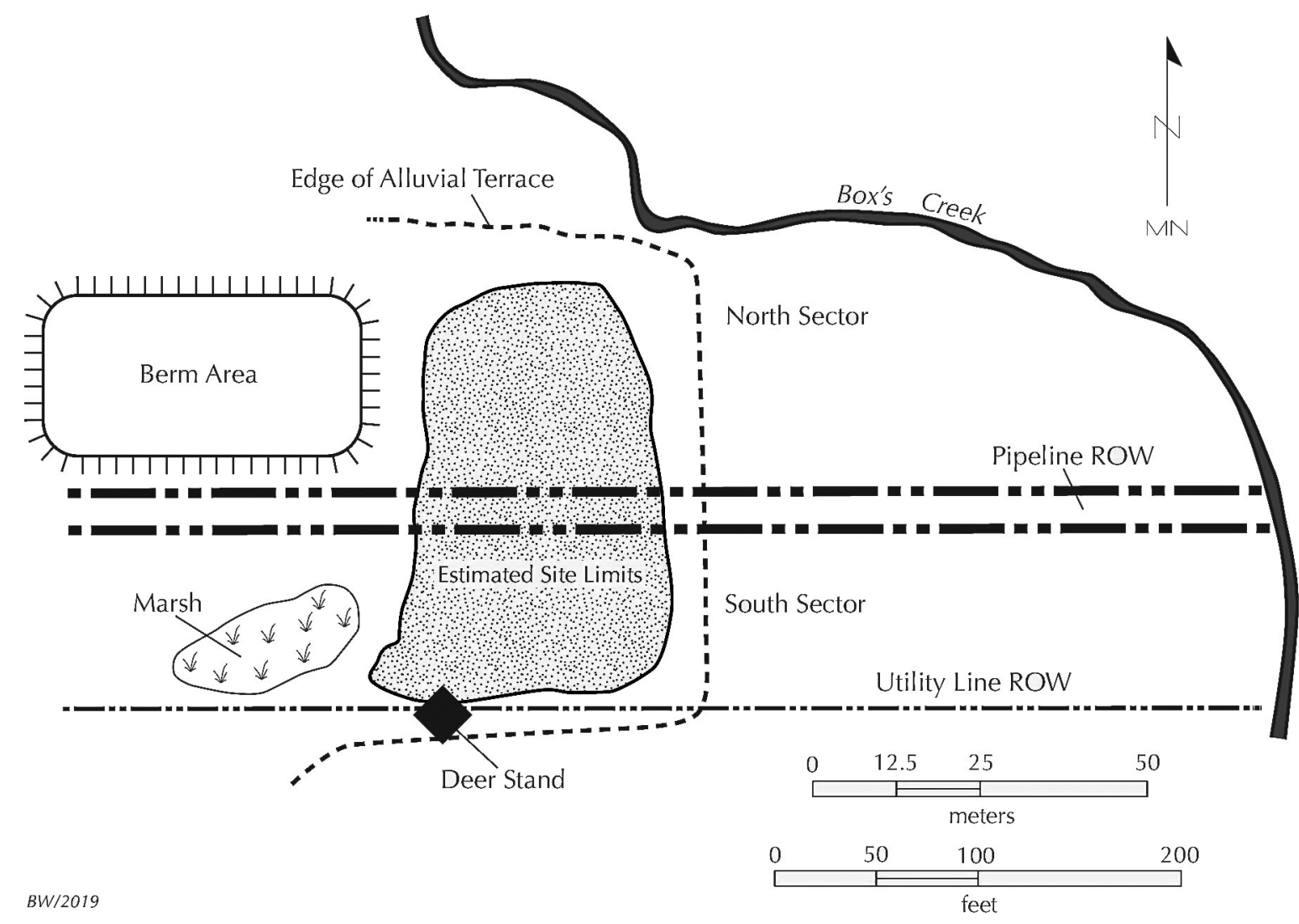

Figure 2. Site map area of the Long site and natural and cultural features noted in the text.

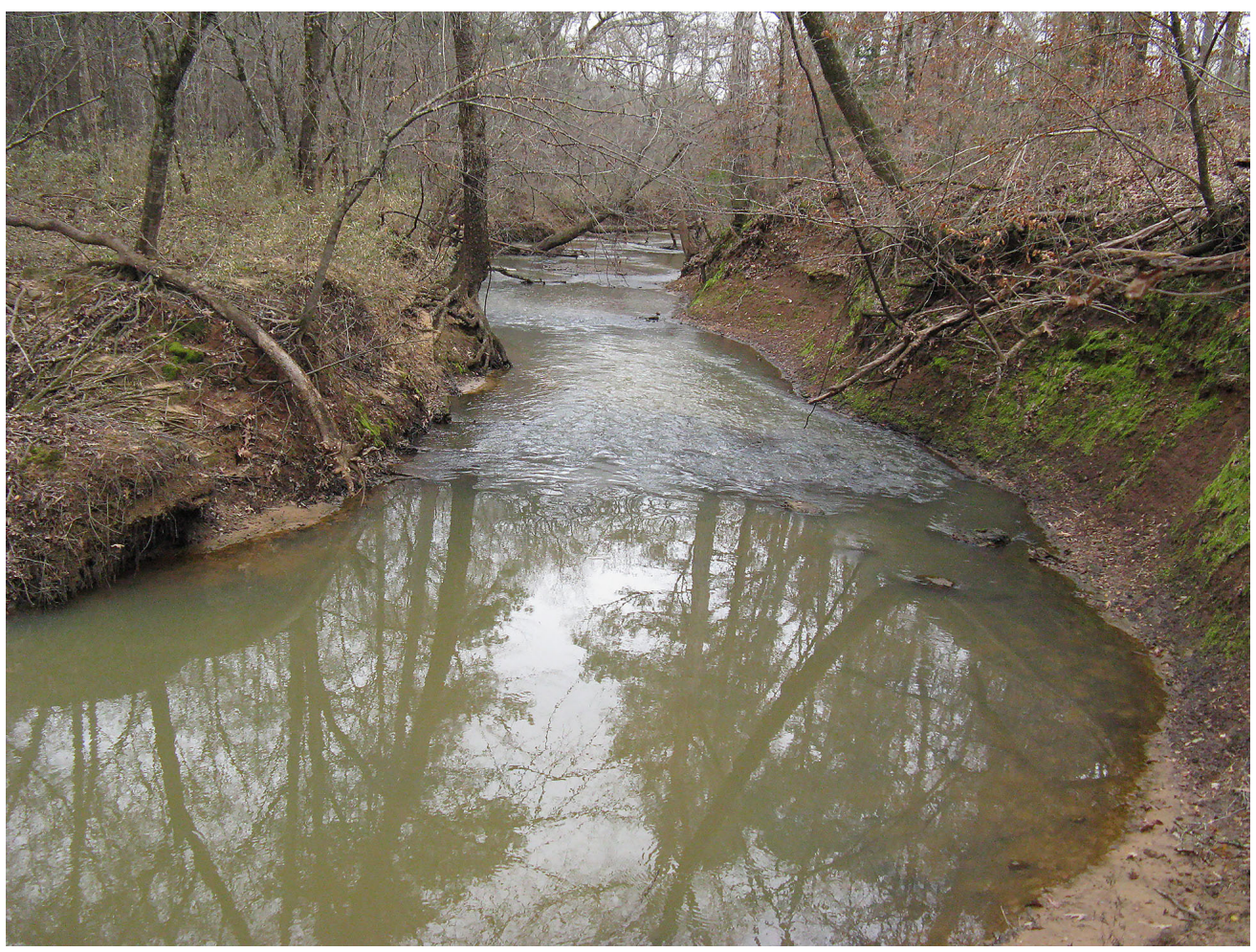

Figure 3. Box's Creek, looking west. 


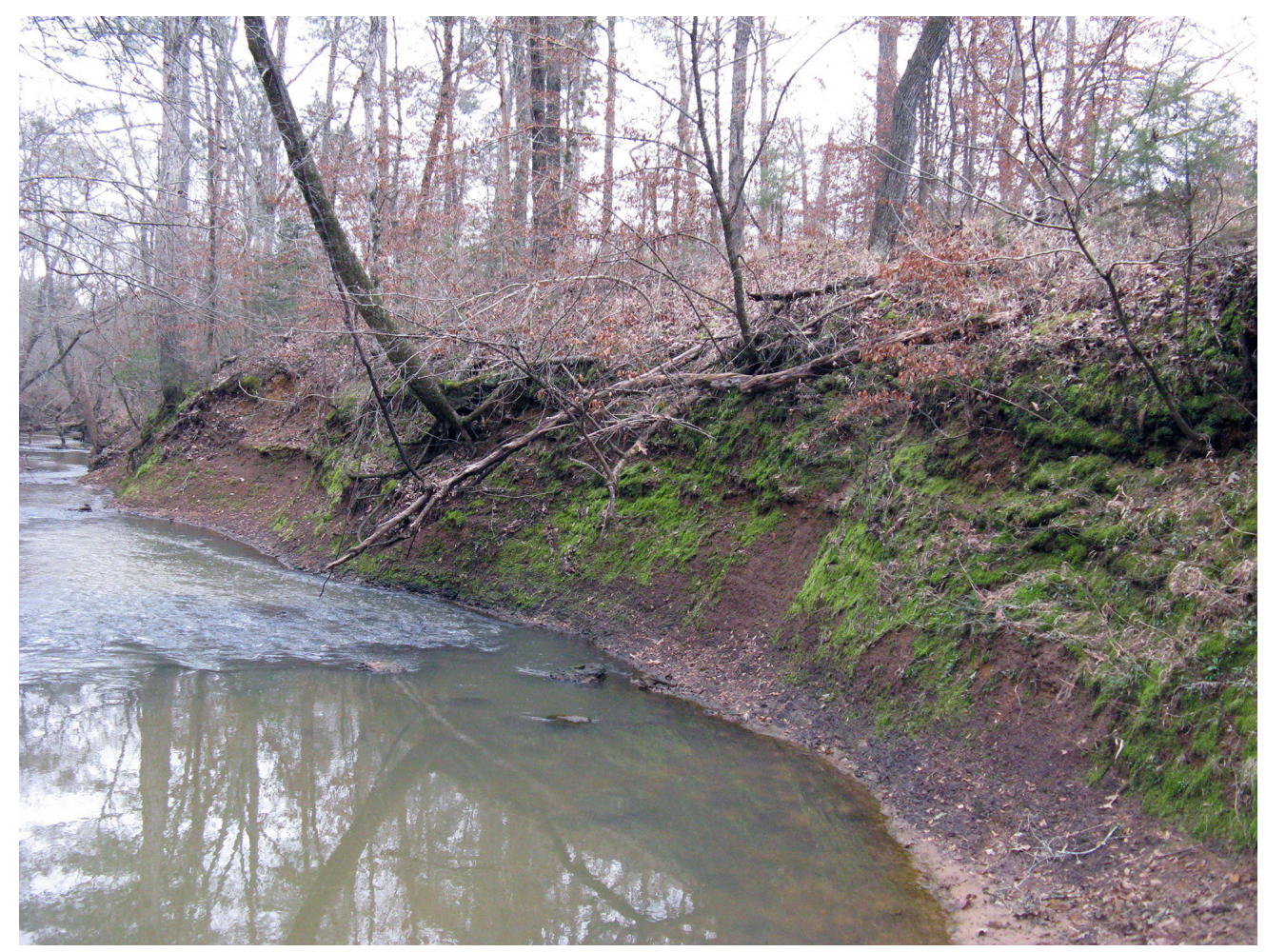

Figure 4. Cut bank along Box's Creek adjacent to the Long site.

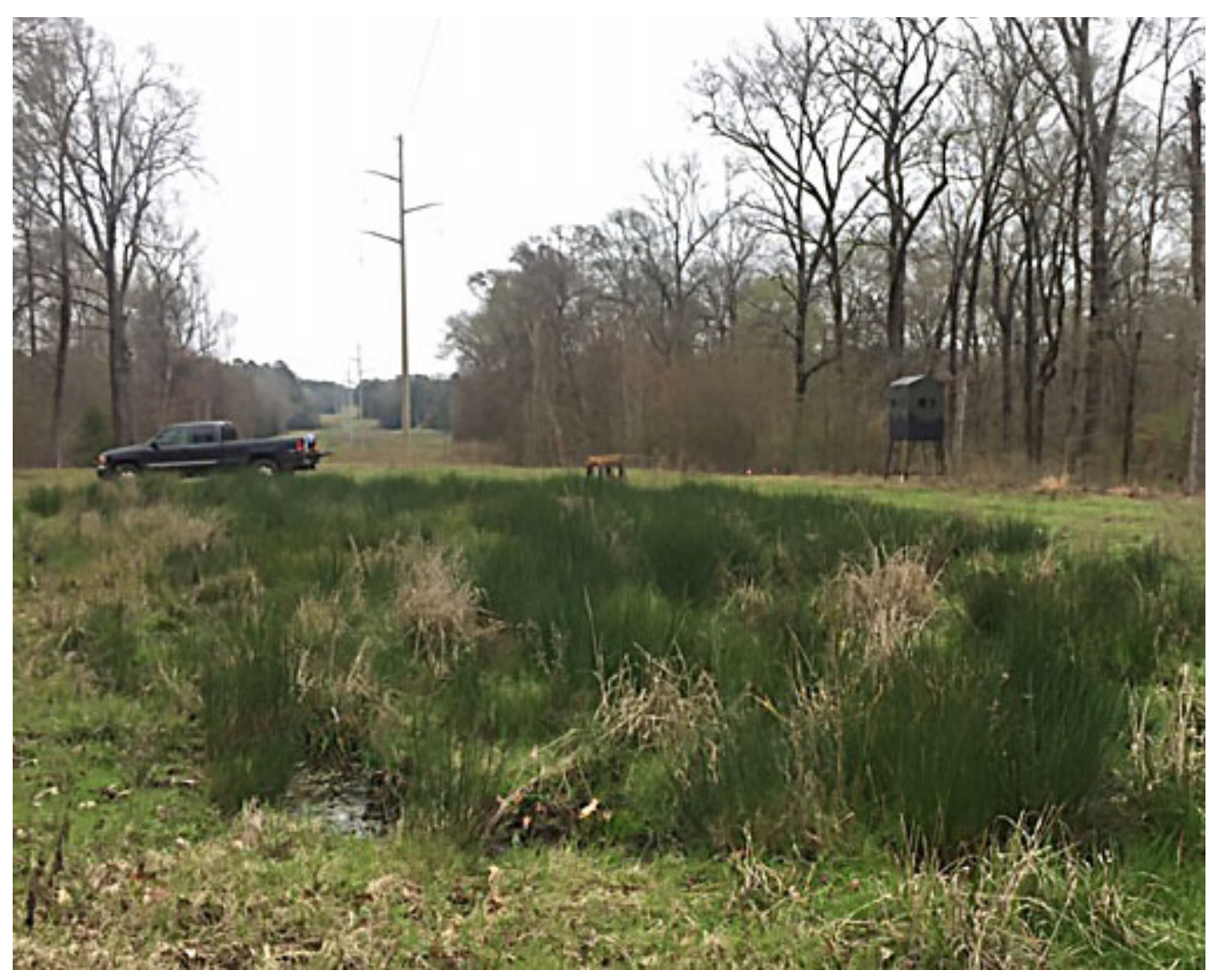

Figure 5. Looking east over the marsh towards the South sector. Screen is at ST 23; note the deer stand at the southern end of the site. 
Just west of the North Sector of the Long site is a 20 m north-south by $30 \mathrm{~m}$ east-west soil berm (see Figure 2), and the elevation is the same both inside and outside of the berm. The berm itself is ca. 1.2-1.5 $\mathrm{m}$ in height, and was likely created by a bulldozer that piled up sediments during its construction. Inside the berm is thick brush, saplings, and trees. The soil inside the berm is a black oily clay soil. According to the landowner the berm has been there as long as he can remember, since the 1940s. He thinks the berm was some sort of overflow pit connected to a nearby oil well about 300 m away; the underground pipeline runs directly beside it (see Figure 2). It has been there long enough to have full grown trees growing inside it. The west edge of the North sector runs north-south within a few meters of the berm.

There is a modern deer stand along the south border of the South sector. It is about $10 \mathrm{~m}$ from the southwestern corner of the sector boundary and about $20 \mathrm{~m}$ from the marsh (see Figures 2 and 5).

Surface visibility across both sectors of the site was poor. The South sector was covered in grass, weeds, and hay (Figure 6a-c), while the North sector was covered in forest debris (i.e., leaves and mulched up saplings) along with standing trees (Figure $7 \mathrm{a}-\mathrm{b}$ ). There was no bare ground on the Long site and no artifacts visible on the surface of the site.

During the course of the archaeological investigations, as previously mentioned, a total of 136 shovel tests were excavated at the Long site: 102 shovel tests in the South sector and 34 in the North sector (Figure 8a-b; see also Appendix 1). Of these, 86 shovel tests in the South sector (84 percent) contain archaeological deposits and material culture remains, compared to only 50 percent $(n=17)$ of the shovel tests in the North sector. Shovel tests $35 \mathrm{~cm}$ in diameter were excavated in no particular order in $20 \mathrm{~cm}$ levels down to the B-horizon clay sub-soils or $100 \mathrm{~cm}$ bs, the approximate maximum depth reachable by shovel. The excavated matrix was then screened through a $0.635-\mathrm{cm}$ wire mesh screen. The GPS location, the depth, texture, and color of the sediments in each shovel test, and the presence of cultural materials by depth, was recorded in the field (see Appendix 1). Artifacts, if any, were collected in $20 \mathrm{~cm}$ levels in each positive shovel test.

On the basis of the shovel tests, the archaeological deposits in the South sector cover a ca. $50 \mathrm{~m}$ x $30 \mathrm{~m}$ area (Figure 9), while the archaeological deposits in the North sector extend over a ca. $40 \mathrm{~m}$ x $20 \mathrm{~m}$ area (see below). The underground pipeline bisects the site from east to west (see Figure 2) and its construction must have removed a substantial portion of the Long site.

Several possible cultural features were encountered in the shovel testing at the Long site, primarily in the southern parts of the South sector (Figure 10), but not within the areas with the highest densities of prehistoric artifacts (see below). There is a $30-\mathrm{cm}$ wide black stain between 23 $40 \mathrm{~cm}$ bs in ST 27 in the South sector, possibly a small pit, and another black stain between 24-35 $\mathrm{cm}$ bs in ST 104 in the South sector. Two other shovel tests in the South sector (ST 132 and ST 135) had dark gray fine sandy loam sediments between 0-51 and 0-53 cm bs; these areas may have midden or anthropogenic deposits. ST 43 had a consolidated ashy deposit between 0-20 cm bs, and it may represent part of another feature.

Lastly, ST 37 had a very distinctive yellow (10YR 8/8) fine sandy loam deposit between 14-30 $\mathrm{cm}$; no other shovel tests on the site had any yellow sand sediments. It is possible that this yellow sand was brought into the site by Caddo peoples as part of a deliberate construction, perhaps a house floor zone. 

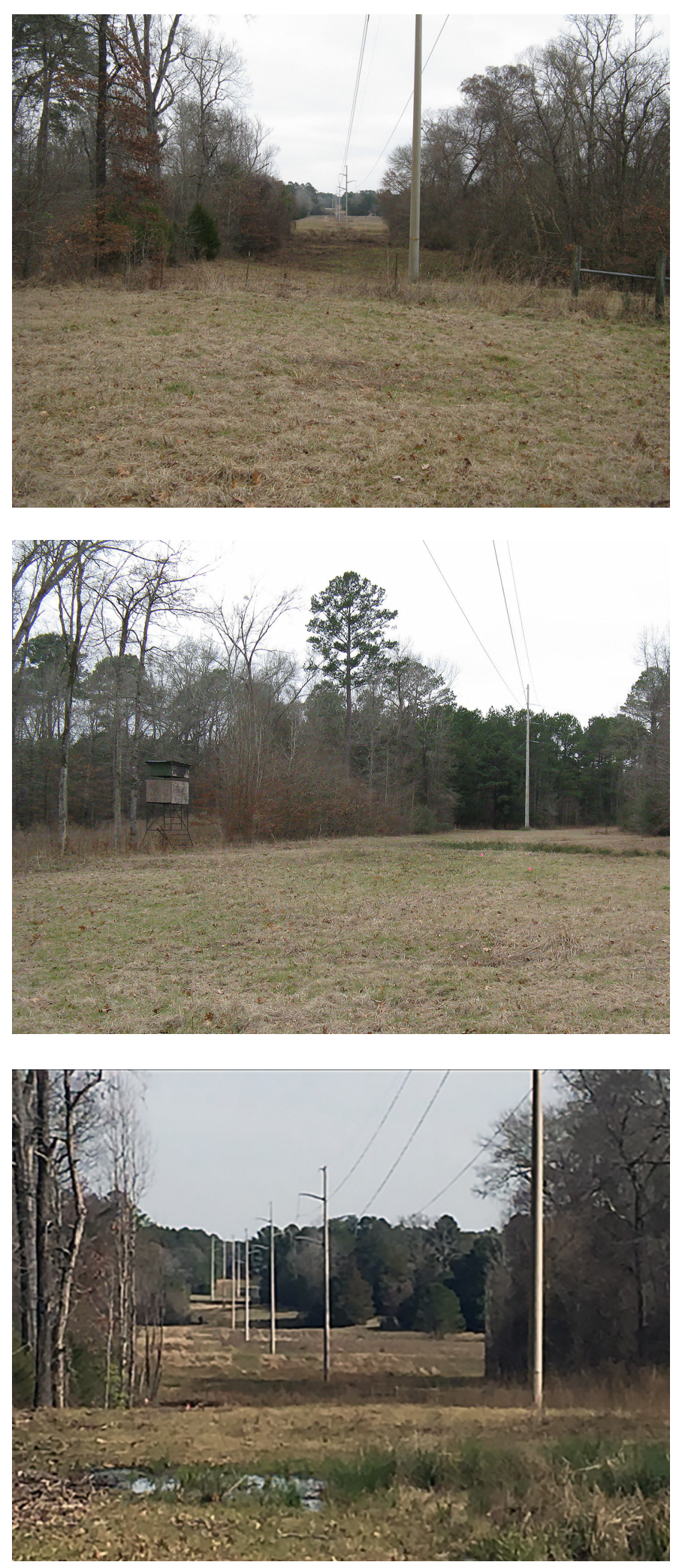

Figure 6. Views of the South sector at the Long site: a, looking east from the middle of the sector; Box's Creek is in the background, running north to south; $b$, looking west from the property line fence; the dark green area is the marsh and the deer stand is at the southern end of the sector; $c$, looking east across the marsh to the South sector; Box's Creek east of the alluvial terrace. 

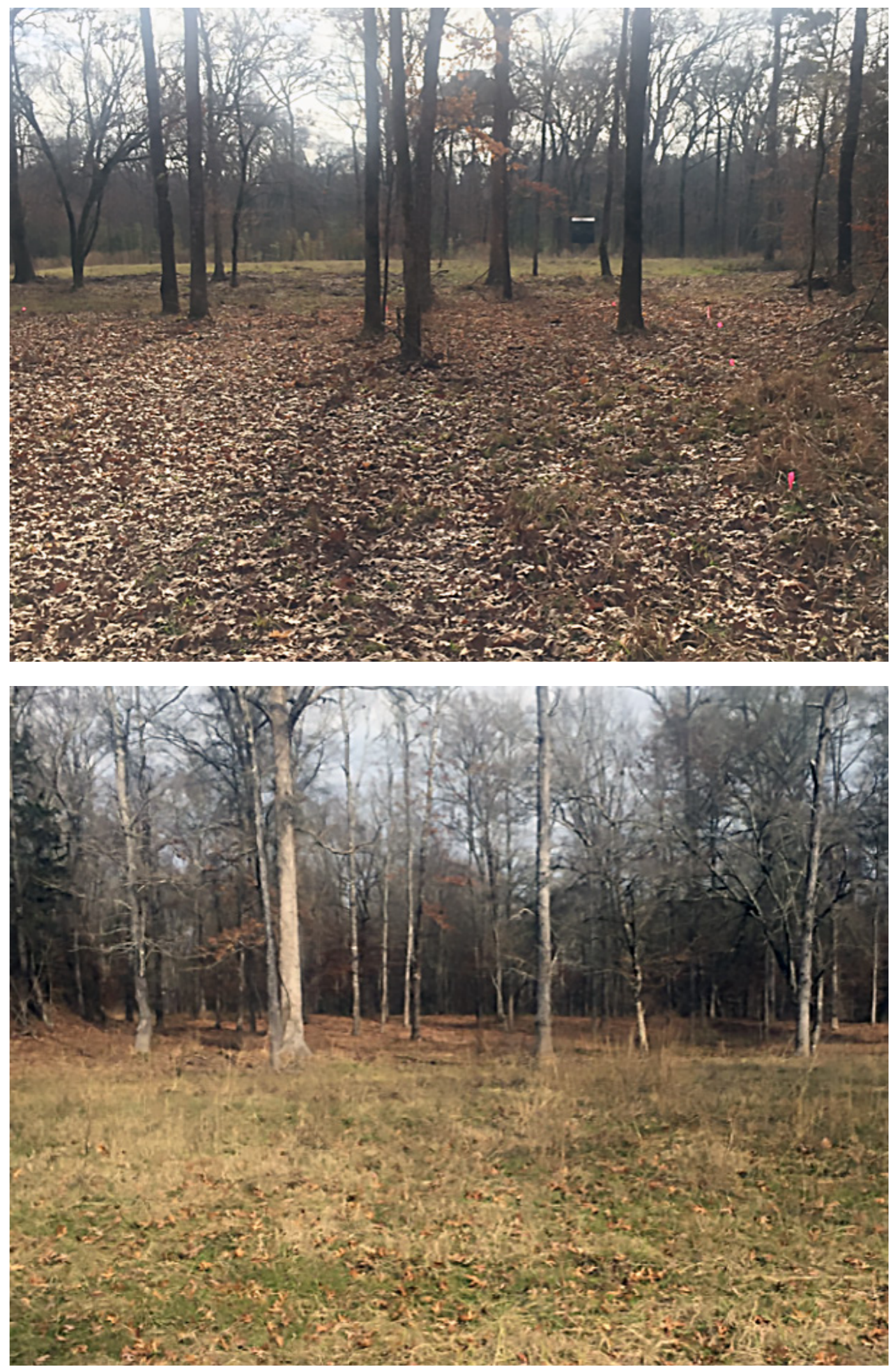

Figure 7. Views of the North sector of the Long site: a, looking south across the North sector from its northwestern corner; vicinity of ST 7 and ST 8; b, looking north from the deer stand across the South sector to the North sector. 


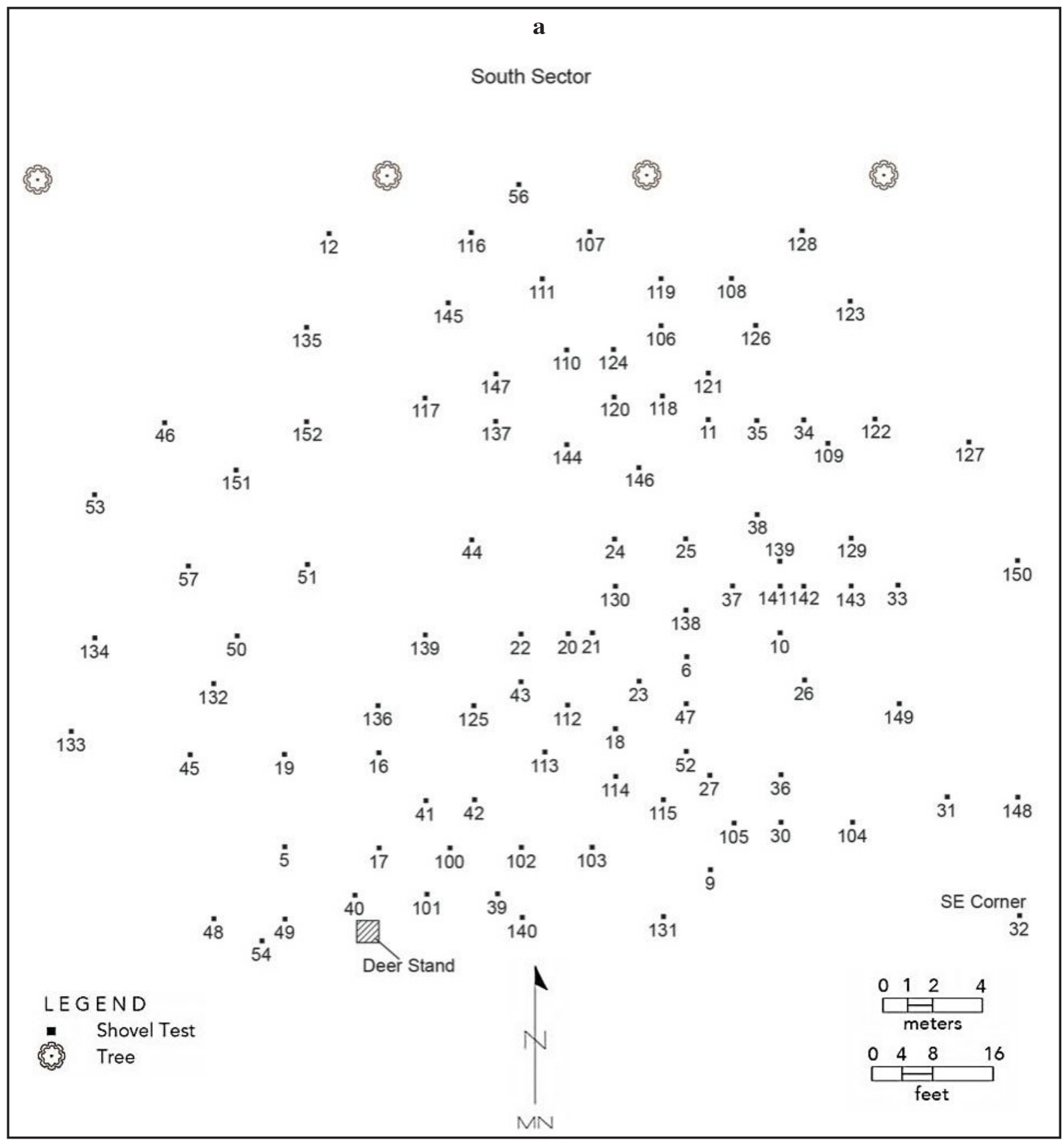

Figure 8. Shovel test locations in the South and North sectors at the Long site: a, South sector; b, North sector.

\section{Prehistoric Artifact Assemblage}

\section{South Sector}

In the South Sector, 83 shovel tests have prehistoric artifacts in the archaeological deposits, including ceramic vessel sherds, ceramic pipe sherds, burned clay, dart points and arrow points, flake tools and bifaces, cores and lithic debris, red ochre pieces, ground stone tools, fire-cracked rock, wood charcoal, charred nutshell pieces, and burned animal bones (Table 1, see also Figure 9). The mean density of prehistoric artifacts in the South sector positive shovel tests is impressive: 16.7 artifacts per 


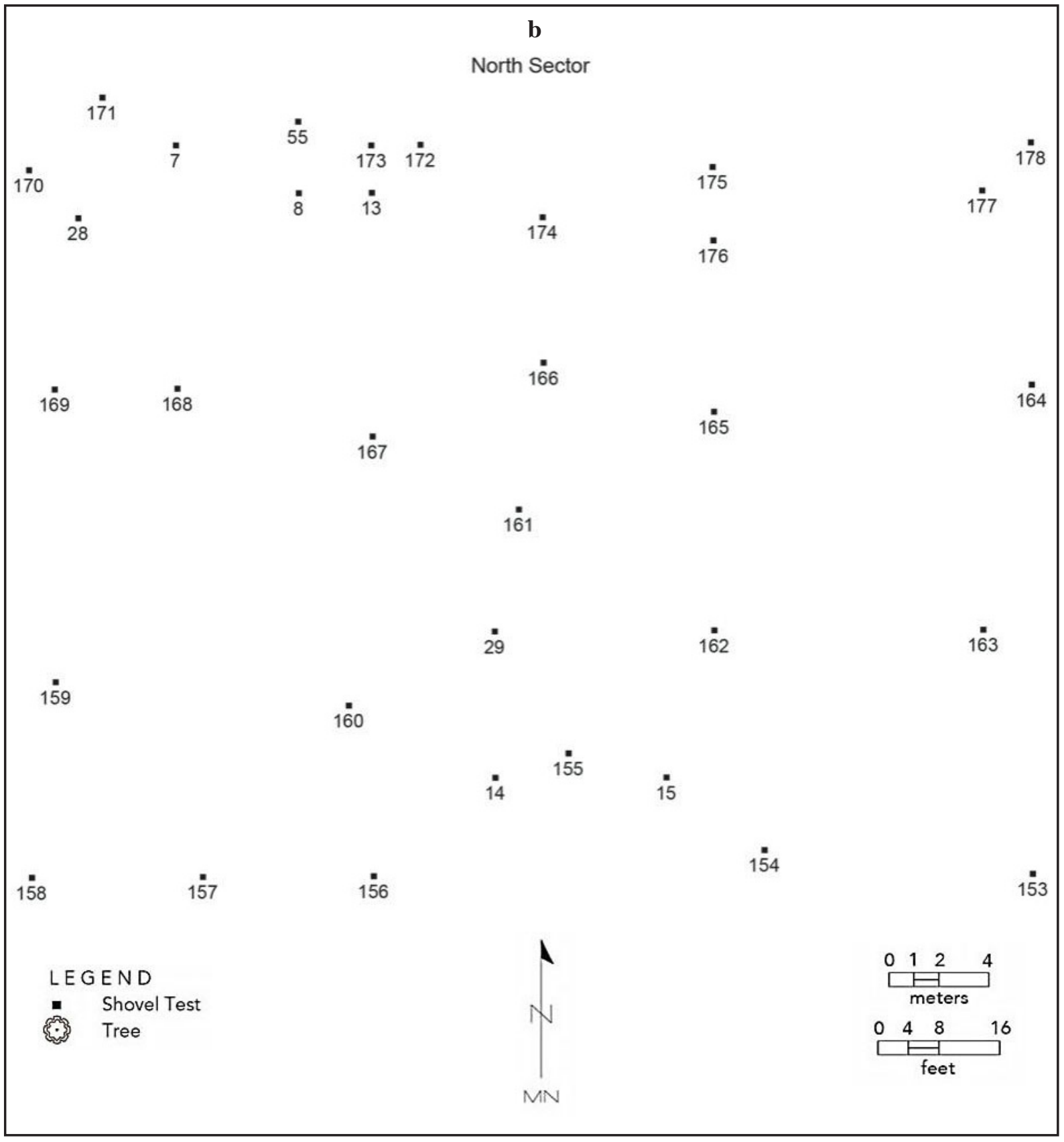

Figure 8. Shovel test locations in the South and North sectors at the Long site: a, South sector; b, North sector.

positive shovel test, with a range of 1-88 artifacts per positive shovel test; this is a mean density of ca. 133.6 artifacts per square meter of archaeological deposits in this sector.

Based on the total number of prehistoric artifacts in the South sector shovel tests, there are three high density artifact clusters (based on the highest artifact numbers in 10 different shovel tests) between ca. 10-25 square meters in size in the sector (Figure 11; see also Table 1). There are also three other shovel tests (ST 42,143, and 147) in non-artifact cluster areas that have high numbers of artifacts. The distribution of high number of ceramic sherds in the shovel tests $(>10$ sherds per shovel test), the main artifact category in the clusters and high density areas, is discussed below. 


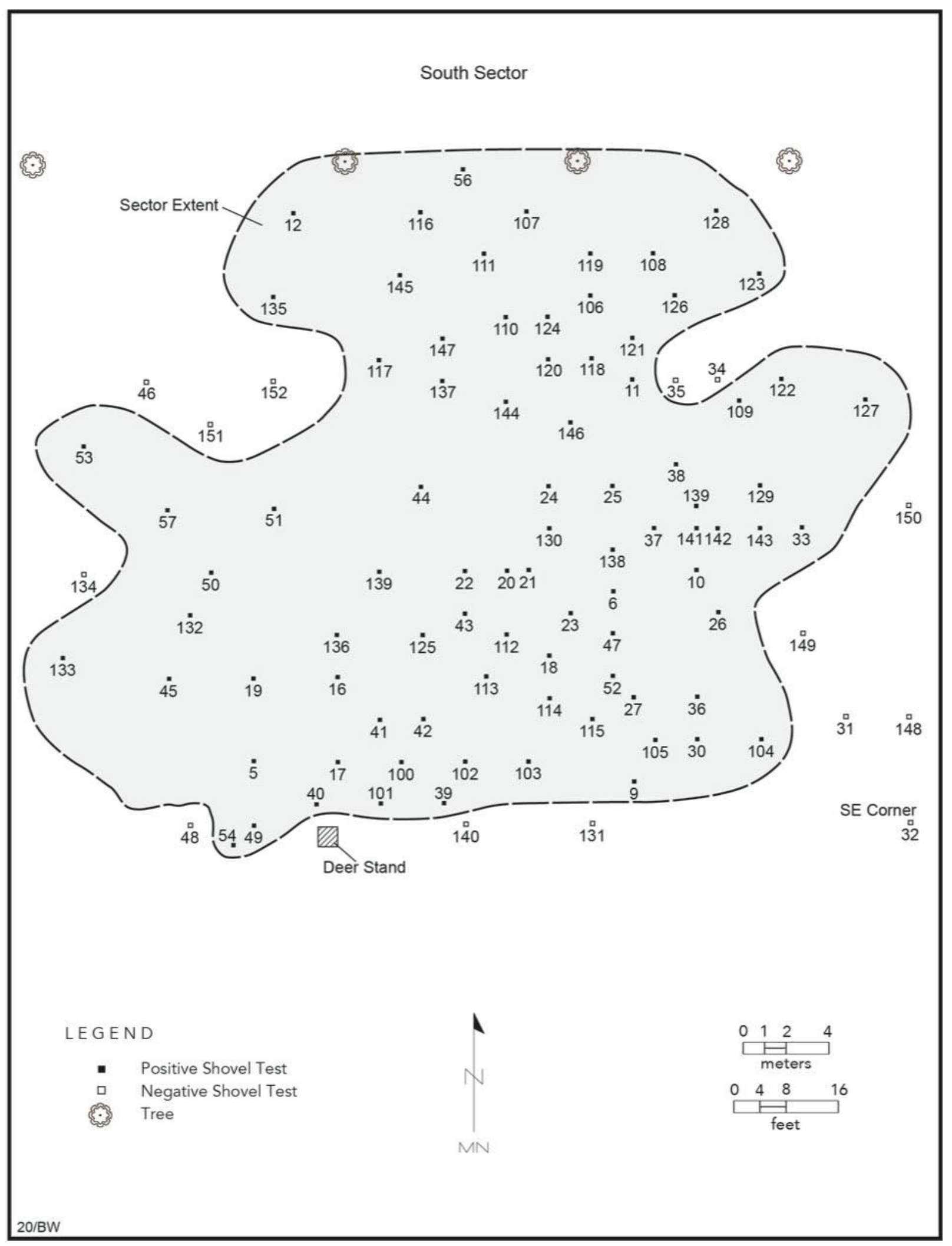

Figure 9. Extent of archaeological deposits in the South sector at the Long site, based on positive shovel tests. 


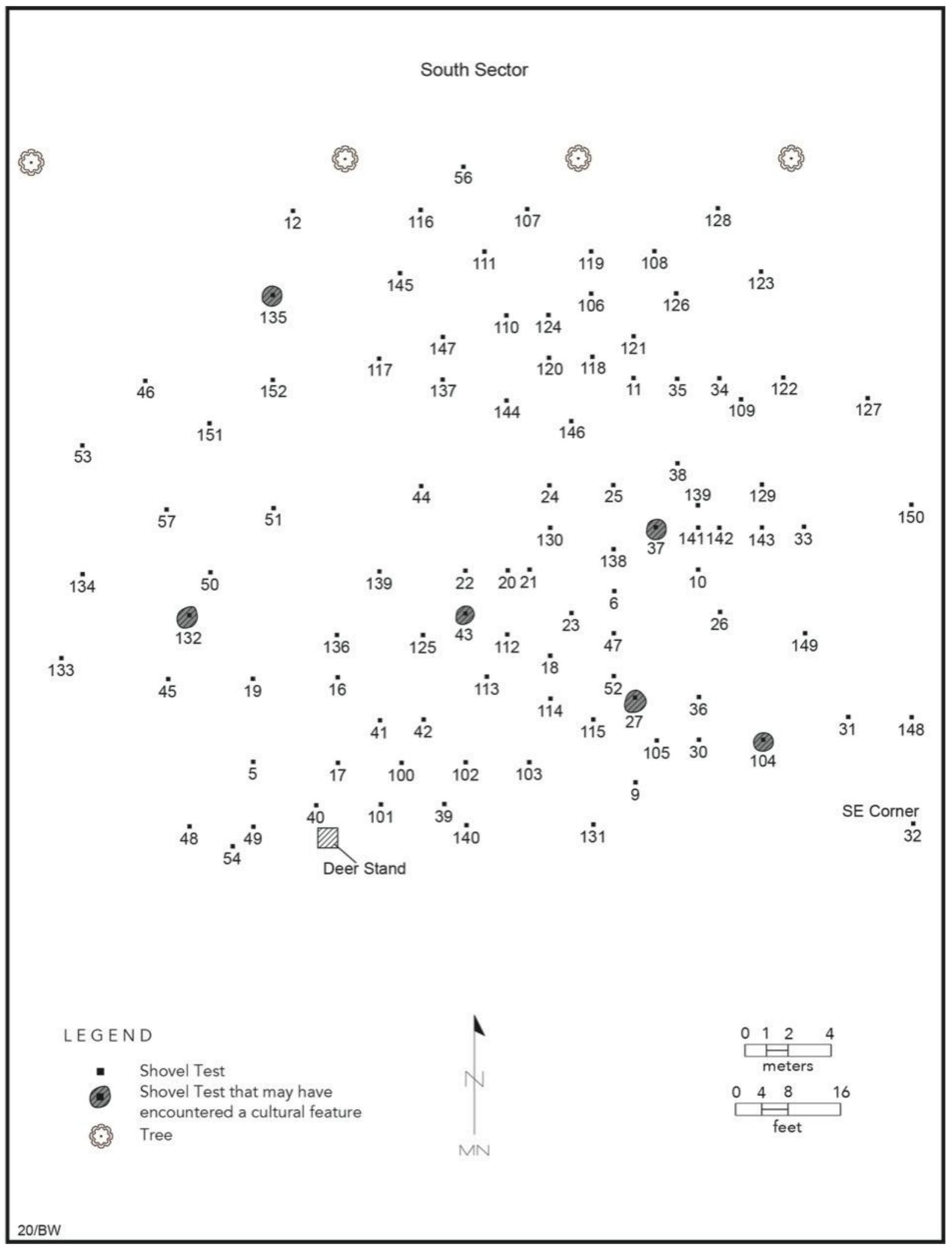

Figure 10. Distribution of shovel tests in the South sector at the Long site that may have encountered feature deposits. 
Table 1. Prehistoric artifacts recovered from shovel tests in the South sector at the Long site.

\begin{tabular}{|c|c|c|c|c|c|c|c|c|c|}
\hline ST No. & PS & DS & AP & DP & LD & GS & Bif/FT/C & Other* & $\mathrm{N}$ \\
\hline ST 1 & - & - & - & - & 3 & - & $-/-/-$ & - & 3 \\
\hline ST 3 & 4 & 1 & - & - & 3 & - & $-/ 1 /-$ & 1 & 10 \\
\hline ST 4 & 1 & 4 & - & - & 4 & - & $-/-/-$ & 1 & 10 \\
\hline ST 5 & 7 & 12 & - & - & 18 & - & $-/ 2 / 2$ & - & 41 \\
\hline ST 6 & 12 & 14 & - & - & 8 & - & $-/-/-$ & 1 & 35 \\
\hline ST 9 & - & - & - & - & 1 & - & $-/-/-$ & - & 1 \\
\hline ST 10 & 2 & 3 & - & - & 5 & 1 & $-/-/-$ & 1 & 12 \\
\hline ST 11 & 2 & 3 & - & - & 4 & - & $-/-/-$ & 2 & 11 \\
\hline ST 12 & 6 & 3 & - & - & 2 & - & $-/-/-$ & - & 11 \\
\hline ST 16 & 4 & 2 & - & - & 5 & - & $-/-/-$ & 3 & 14 \\
\hline ST 17 & 3 & 3 & - & - & 5 & - & $-/ 1 /-$ & - & 12 \\
\hline ST 18 & 15 & 19 & - & - & 27 & - & $1 / 2 / 1$ & 3 & 68 \\
\hline ST 19 & 16 & 12 & 1 & 1 & 20 & - & $-/-/-$ & - & 50 \\
\hline ST 20 & 1 & 1 & - & - & 4 & - & $-/-/-$ & - & 6 \\
\hline ST 21 & 5 & 9 & 1 & - & 8 & - & $-/ 1 /-$ & 1 & 25 \\
\hline ST 22 & 5 & 7 & - & - & 2 & - & $-/-/-$ & 1 & 15 \\
\hline ST 23 & 34 & 26 & 2 & - & 15 & 1 & $1 / 1 / 1$ & 7 & 88 \\
\hline ST 24 & 6 & 5 & - & - & 7 & - & $-/-/ 1$ & - & 19 \\
\hline ST 25 & 5 & 2 & - & - & 5 & - & $1 /-/-$ & - & 13 \\
\hline ST 26 & 4 & 4 & - & - & 4 & 1 & $-/-/-$ & 1 & 14 \\
\hline ST 27 & 2 & 1 & - & - & 6 & - & $-/-/-$ & 4 & 13 \\
\hline ST 33 & - & 3 & 1 & - & 3 & - & $-/-/-$ & - & 7 \\
\hline ST 36 & 2 & 1 & - & - & 3 & - & $-/-/-$ & - & 6 \\
\hline ST 37 & - & 4 & - & - & 2 & 1 & $-/-/-$ & - & 7 \\
\hline ST 38 & 2 & 3 & - & - & 4 & - & $-/-/-$ & - & 9 \\
\hline ST 39 & 1 & 3 & - & - & 4 & - & $-/-/-$ & - & 8 \\
\hline ST 40 & 4 & 1 & - & - & 1 & - & $-/-/-$ & - & 6 \\
\hline ST 41 & 1 & 1 & - & - & 4 & - & $-/-/-$ & - & 6 \\
\hline ST 42 & 22 & 16 & 1 & - & 23 & - & $-/-/-$ & 3 & 65 \\
\hline ST 43 & - & 1 & - & - & - & - & $-/-/-$ & - & 1 \\
\hline ST 44 & 5 & - & - & - & 4 & - & $-/-/-$ & 1 & 10 \\
\hline ST 45 & 4 & 1 & - & - & 2 & - & $-/-/-$ & - & 7 \\
\hline ST 49 & - & 1 & - & - & - & - & $-/-/-$ & - & 1 \\
\hline ST 50 & 2 & 4 & - & - & 2 & - & $-/-/-$ & - & 8 \\
\hline ST 51 & 1 & 1 & - & - & 2 & - & $-/-/-$ & 1 & 5 \\
\hline ST 52 & 1 & 1 & - & - & 1 & - & $-/-/-$ & - & 3 \\
\hline ST 53 & 1 & 1 & - & - & 1 & - & $-/-/-$ & - & 3 \\
\hline ST 54 & 1 & 1 & - & - & - & 1 & $-/-/-$ & 2 & 5 \\
\hline ST 56 & 2 & 2 & - & - & 1 & - & $-/-/-$ & 1 & 6 \\
\hline ST 57 & 6 & 5 & - & - & 3 & - & $-/-/ 1$ & 2 & 17 \\
\hline ST 100 & - & 1 & - & - & 2 & - & $-/-/-$ & - & 3 \\
\hline ST 101 & 9 & 4 & - & - & 4 & - & 1/-/- & - & 18 \\
\hline ST 102 & 3 & 2 & - & - & 4 & - & $-/-/-$ & 5 & 14 \\
\hline ST 103 & 7 & 8 & - & - & 5 & - & $-/-/-$ & 1 & 21 \\
\hline ST 104 & - & - & - & - & 3 & - & $-/-/-$ & - & 3 \\
\hline
\end{tabular}


Table 1. Prehistoric artifacts recovered from shovel tests in the South sector at the Long site, cont.

\begin{tabular}{|c|c|c|c|c|c|c|c|c|c|}
\hline ST No. & PS & DS & $\mathrm{AP}$ & DP & $\mathrm{LD}$ & GS & $\mathrm{Bif} / \mathrm{FT} / \mathrm{C}$ & Other* & $\mathrm{N}$ \\
\hline ST 105 & - & - & 1 & - & 4 & - & $-/-/-$ & - & 5 \\
\hline ST 106 & 16 & 11 & - & - & 19 & - & $-/-/-$ & 4 & 50 \\
\hline ST 107 & 2 & 1 & - & - & - & - & $-/-/-$ & - & 3 \\
\hline ST 108 & 10 & 6 & - & - & 6 & 2 & $-/-/-$ & 2 & 26 \\
\hline ST 109 & 13 & 4 & - & - & 4 & 1 & $1 /-/-$ & - & 23 \\
\hline ST 110 & 3 & 3 & - & - & 5 & - & $-/-/-$ & 1 & 12 \\
\hline ST 111 & 1 & 1 & - & - & 1 & - & $-/-/-$ & - & 3 \\
\hline ST 112 & 15 & 11 & - & - & 3 & - & $1 / 1 /-$ & 1 & 32 \\
\hline ST 113 & 5 & 3 & 1 & - & 3 & - & $-/-/-$ & - & 12 \\
\hline ST 114 & 4 & 10 & - & - & 8 & - & $-/-/-$ & 5 & 27 \\
\hline ST 115 & - & 1 & - & - & 9 & - & $-/-/-$ & 1 & 11 \\
\hline ST 116 & 3 & - & - & - & 7 & - & $-/-/-$ & - & 10 \\
\hline ST 117 & 10 & 6 & - & - & 9 & - & $-/-/-$ & - & 25 \\
\hline ST 118 & 6 & 7 & - & 1 & 8 & - & $-/-/ 1$ & 2 & 25 \\
\hline ST 119 & 6 & 8 & 1 & - & 2 & - & $-/-/-$ & - & 17 \\
\hline ST 120 & 4 & 1 & - & - & 1 & - & $-/-/-$ & 1 & 7 \\
\hline ST 121 & 12 & 8 & 1 & - & 10 & - & $-/-/-$ & 1 & 32 \\
\hline ST 122 & 4 & 3 & - & - & 3 & - & $-/-/-$ & - & 10 \\
\hline ST 123 & 5 & 3 & - & - & 7 & - & $-/-/-$ & - & 15 \\
\hline ST 124 & 3 & 5 & 1 & - & 1 & - & $-/-/-$ & - & 10 \\
\hline ST 125 & 3 & - & - & - & 5 & - & $-/ 1 /-$ & - & 9 \\
\hline ST 126 & 1 & 4 & - & - & 5 & - & $-/-/-$ & - & 10 \\
\hline ST 127 & 2 & 2 & - & - & 3 & - & $-/-/-$ & - & 7 \\
\hline ST 128 & - & 1 & - & - & 2 & - & $-/ 1 /-$ & - & 4 \\
\hline ST 129 & 12 & 7 & - & - & 7 & - & $1 /-/ 1$ & - & 28 \\
\hline ST 130 & 3 & 4 & - & - & 1 & - & $-/-/-$ & 1 & 9 \\
\hline ST 132 & 2 & 6 & - & - & 2 & - & $-/-/-$ & - & 10 \\
\hline ST 133 & 1 & 1 & - & - & 2 & - & $-/-/-$ & - & 4 \\
\hline ST 135 & 1 & 1 & - & - & - & - & $-/-/-$ & 1 & 3 \\
\hline ST 136 & 2 & 4 & - & - & 7 & - & $-/-/-$ & - & 13 \\
\hline ST 137 & 12 & 3 & - & - & 4 & $-/ 1 /-$ & - & 20 & \\
\hline ST 138 & 14 & 10 & 1 & - & 12 & 1 & $-/ 1 /-$ & 3 & 42 \\
\hline ST 141 & 4 & 9 & - & 1 & 5 & 1 & $-/ 1 /-$ & 1 & 22 \\
\hline ST 142 & 2 & 4 & - & - & 8 & - & $-/-/-$ & - & 14 \\
\hline ST 143 & 16 & 11 & - & - & 5 & - & $-/-/-$ & 1 & 33 \\
\hline ST 144 & 5 & 7 & 1 & - & 9 & - & $-/ 1 /-$ & 1 & 24 \\
\hline ST 146 & 9 & 13 & 1 & - & 11 & - & $-/-/-$ & 2 & 36 \\
\hline ST 147 & 9 & 19 & 2 & - & 8 & - & $-/-/-$ & 3 & 41 \\
\hline Totals & 424 & 387 & 16 & 3 & 439 & 10 & $7 / 15 / 9$ & 72 & 138 \\
\hline
\end{tabular}

$\mathrm{PS}=$ plain sherd; $\mathrm{DS}=$ decorated sherd; $\mathrm{AP}=$ arrow point; $\mathrm{DP}=$ dart point; $\mathrm{LD}=$ lithic debris; $\mathrm{GS}=$ ground stone; Bif=biface; FT=flake tool; core=core

*Other includes wood charcoal, nutshell, animal bone, burned clay, ceramic pipe sherd, fire-cracked rock, and red ochre 


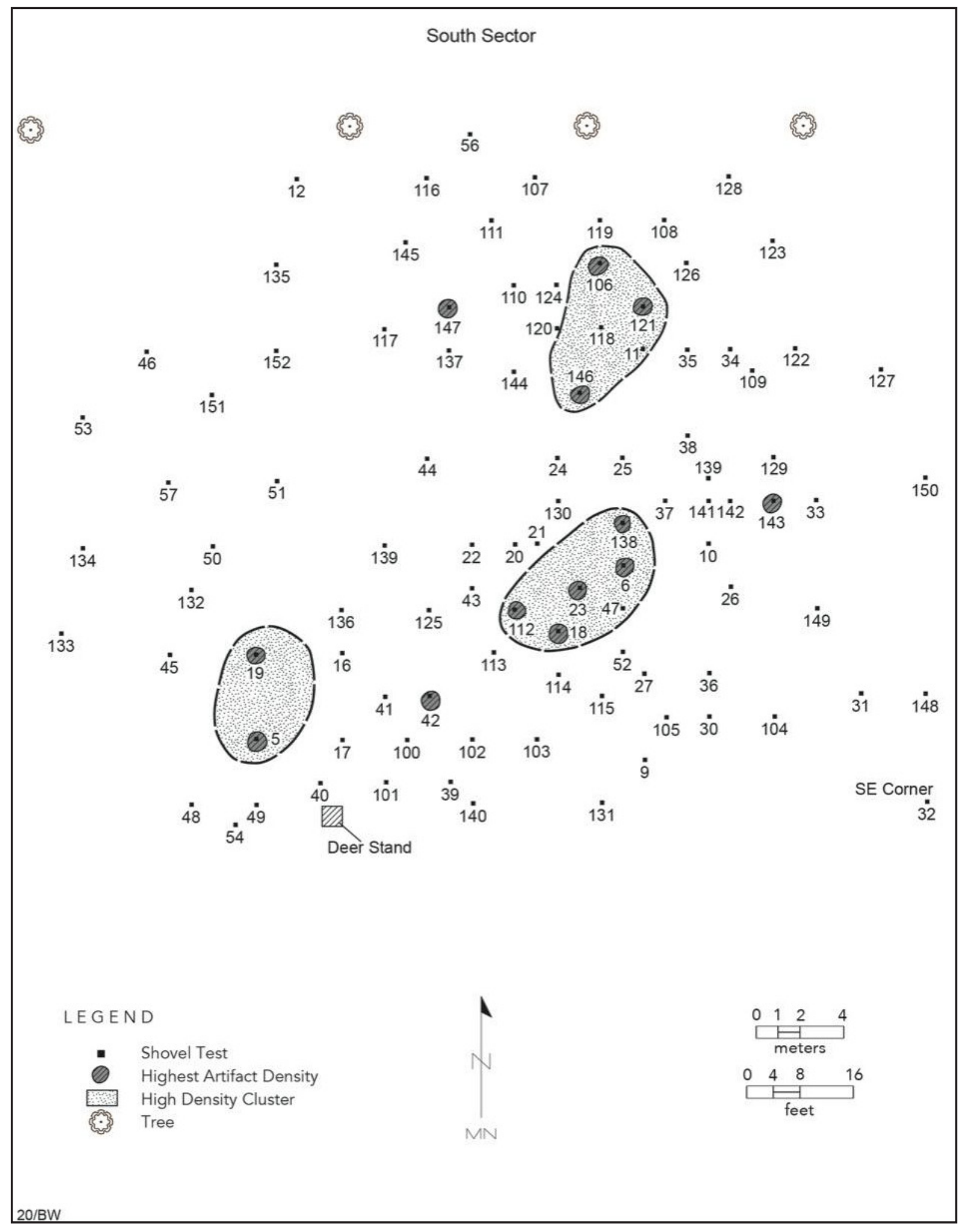

Figure 11. High artifact density clusters in the South sector. 
Prehistoric artifacts have been recovered to depths of $80 \mathrm{~cm}$ bs in the South sector, but less than 0.4 percent are from the $60-80 \mathrm{~cm}$ bs level (Table 2). Another 17.5 percent of the artifacts are from $40-60 \mathrm{~cm}$ bs, but the majority of the artifacts ( 82.2 percent) are concentrated from $0-40 \mathrm{~cm} \mathrm{bs}$; this depth range represents the principal occupational deposit in this sector of the Long site. More than 93 percent of the recovered artifacts occur at these depths, as do 100 percent of the ground stone tools and 87 percent of the flake tools. Conversely, all of the cores are from 0-60 cm bs, and 100 percent of the bifaces are from $20-80 \mathrm{~cm}$ bs (Table 2).

Table 2. Depth of prehistoric artifacts in the South sector shovel tests.

\begin{tabular}{llllllllll}
\hline Depth & PS & DS & AP & DP & LD & GS & Bif/FT/C & Other* & N \\
\hline $0-20 \mathrm{~cm}$ & 129 & 132 & 10 & 1 & 192 & 3 & $-/ 7 / 3$ & 25 & 502 \\
$20-40 \mathrm{~cm}$ & 203 & 191 & 5 & 1 & 180 & 7 & $4 / 6 / 4$ & 33 & 634 \\
$40-60 \mathrm{~cm}$ & 91 & 62 & 1 & 1 & 67 & - & $2 / 2 / 2$ & 14 & 242 \\
$60-80 \mathrm{~cm}$ & 1 & 2 & - & - & 1 & - & $1 /-/-$ & - & 5 \\
\hline Totals & 424 & 387 & 16 & 3 & 439 & 10 & $7 / 15 / 9$ & 72 & 1383 \\
\hline
\end{tabular}

$\mathrm{PS}=$ plain sherd; $\mathrm{DS}=$ decorated sherd; $\mathrm{AP}=$ arrow point; $\mathrm{DP}=$ dart point; $\mathrm{LD}=$ lithic debris; $\mathrm{GS}=$ ground stone tool; $\mathrm{Bif}=$ biface; $\mathrm{FT}=$ flake tool; $\mathrm{C}=$ core

*Other includes wood charcoal, nutshell, animal bone, burned clay, ceramic pipe sherd, fire-cracked rock, and red ochre (see Tables 10 and 18-22, below)

\section{North Sector}

Seventeen shovel tests in the North sector contain prehistoric artifacts, primarily ancestral Caddo ceramic vessel sherds and lithic debris (Table 3). The range of artifacts by shovel test is 1-16, with a mean density of 5.06 per positive shovel test, or ca. 40.5 artifacts per square meter of archaeological deposits.

The North sector prehistoric artifacts are distributed in the southern, western, and northern portions of the alluvial terrace landform in the sector (Figure 12). Two areas at opposite ends of the sector have the highest densities of artifacts (9-16 artifacts per shovel test, see Table 3).

Prehistoric artifacts in the North sector occur from $0-80 \mathrm{~cm}$ bs, with the highest densities between 20-60 cm bs (Table 4), but almost comparable densities between 0-20 $\mathrm{cm}$ bs and $60-80 \mathrm{~cm}$ bs. Ceramic vessel sherds are most common between $20-60 \mathrm{~cm}$ bs, while the lithic debris is most abundant between $0-20 \mathrm{~cm}$ bs and $40-60 \mathrm{~cm}$ bs. The one piece of modified red ochre is in the 0-20 $\mathrm{cm}$ bs level, and the few pieces of wood charcoal occur from $20-80 \mathrm{~cm}$ bs.

\section{Ceramic Vessel Sherds}

Ancestral Caddo ceramic sherds are particularly abundant in the South sector, with 424 plain sherds and 387 decorated sherds. This is 9.8 sherds per positive shovel test, or ca. 78.4 sherds per square meter of archaeological deposits in the South sector. Plotting the distribution of shovel tests with more than 10 sherds per positive shovel test has identified two principal sherd clusters in the southern and northern parts of the sector, each covering between ca. 90-100 square meters (Figure 13); these likely represent areas with houses and outdoor activity areas. There are two much smaller 
Table 3. Prehistoric artifacts recovered from shovel tests in the North sector.

\begin{tabular}{llllll}
\hline ST No. & Sherds & Lithic Debris & Red Ochre & Wood & N \\
& Charcoal & & & - & 4 \\
7 & 2 & 2 & - & 1 & 16 \\
8 & 13 & 2 & - & - & 2 \\
13 & - & 4 & - & 1 & 6 \\
55 & 1 & - & - & - & 2 \\
156 & 2 & - & - & - & 2 \\
157 & 2 & 4 & - & 2 & 9 \\
158 & 3 & 1 & - & - & 4 \\
164 & 3 & - & - & - & 2 \\
166 & 2 & 1 & - & - & 1 \\
169 & 2 & - & - & - & 2 \\
170 & 1 & - & - & - & 12 \\
171 & 2 & 8 & - & - & 6 \\
172 & 4 & 1 & - & - & 5 \\
174 & 3 & 3 & - & - & 2 \\
175 & 3 & - & - & - & 4 \\
176 & 5 & - & - & - & 86 \\
177 & 2 & 2 & 1 & 4 & \\
178 & 1 & 30 & & & \\
\hline Totals & 51 & & & - & \\
\hline
\end{tabular}

Table 4. Depth of prehistoric artifacts in the North sector shovel tests.

\begin{tabular}{llllll}
\hline $\begin{array}{l}\text { Depth } \\
\text { (cm bs) }\end{array}$ & $\begin{array}{l}\text { Sherds } \\
\text { Debris }\end{array}$ & $\begin{array}{l}\text { Lithic } \\
\text { Ochre }\end{array}$ & $\begin{array}{l}\text { Red } \\
\text { Charcoal }\end{array}$ & Wood & N \\
\hline $0-20$ & 10 & 8 & 1 & - & 19 \\
$20-40$ & 15 & 6 & - & 2 & 23 \\
$40-60$ & 16 & 9 & - & 1 & 26 \\
$60-80$ & 10 & 7 & - & 4 & 86 \\
\hline Totals & 51 & 30 & 1 & & 4 \\
\hline
\end{tabular}

sherd clusters (ca. 5-15 square meters) to the east and west of the principal sherd clusters (Figure 13), and these may simply represent other outdoor activity areas. Three of the four sherd clusters are spatially associated with the high density artifact clusters depicted in Figure 13.

The ancestral Caddo sherds in the South sector at the Long site include sherds from plain ware, utility ware, and fine ware vessels. The plain ware sherds account for 52.4 percent of the assemblage (Table 5); however, only 20.9 percent of the rim sherds are from plain vessels. Utility ware sherds comprise 40.0 percent of the assemblage, and only 7.7 percent of the sherds are from fine wares; fine ware rim sherds account for 23.9 percent of the rim sherd sample, however. 


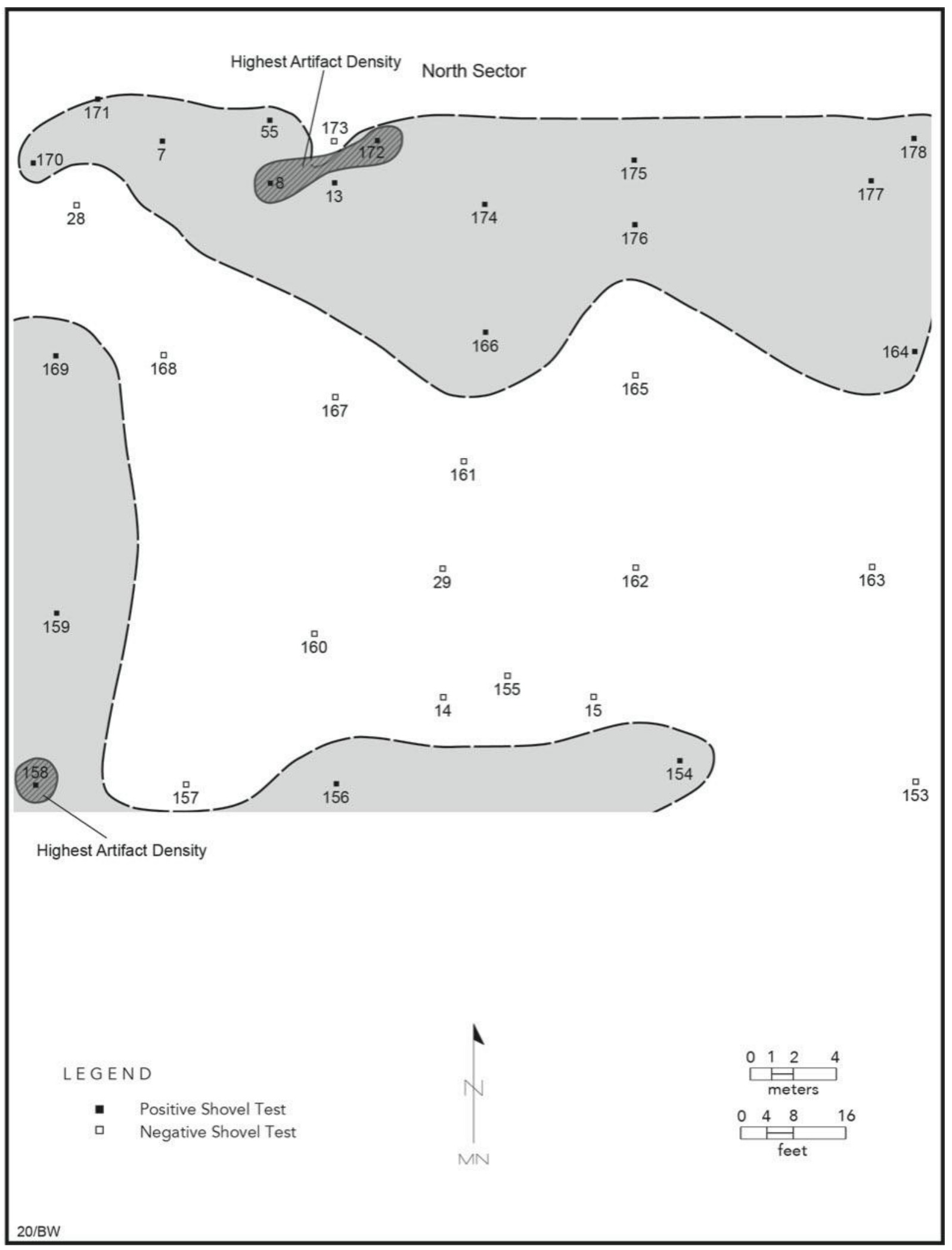

Figure 12. Distribution of positive shovel tests and areas with highest density of artifacts in the shovel tests in the North sector at the Long site. 


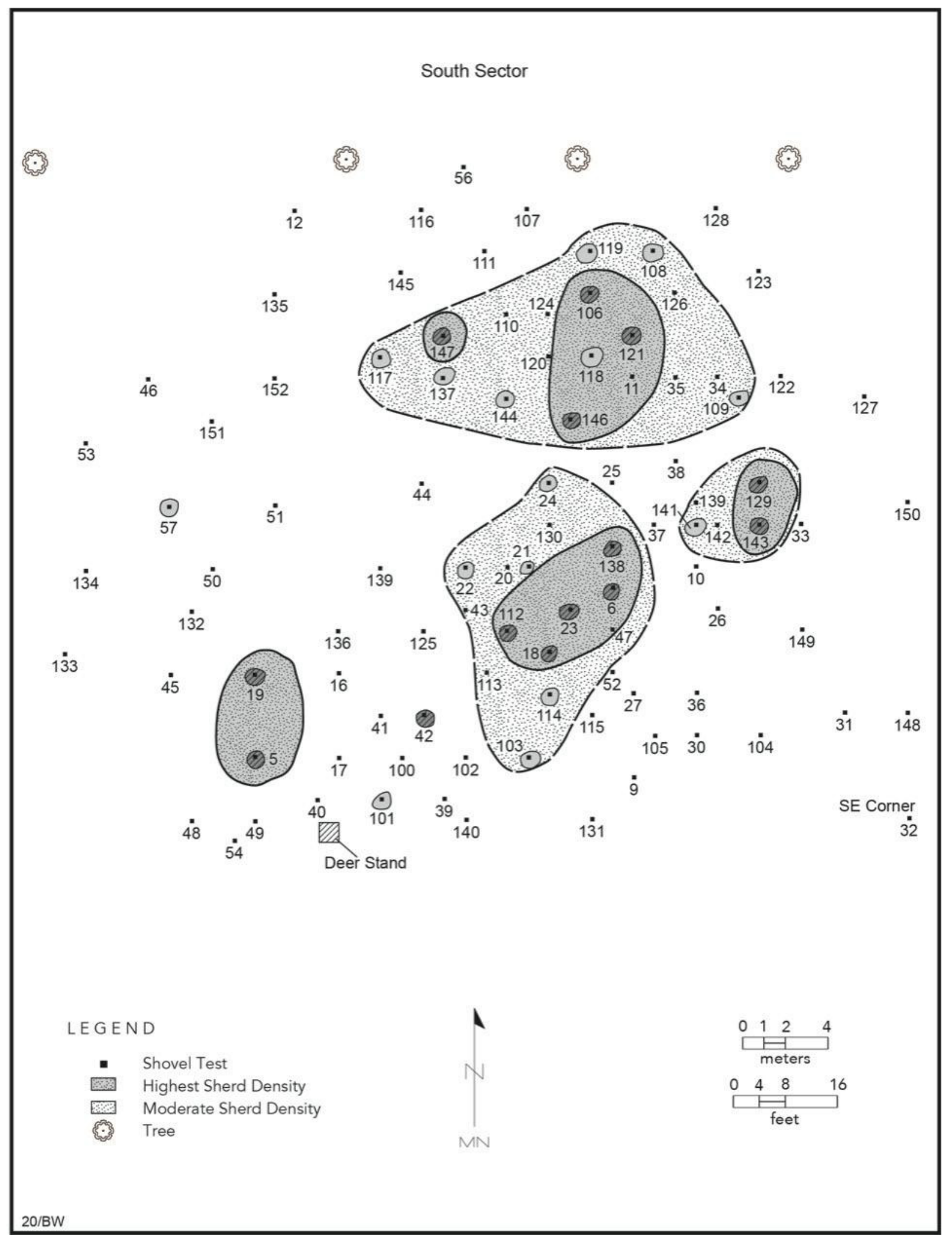

Figure 13. High sherd density clusters in positive shovel tests in the South sector. 
Table 5. Ancestral Caddo ceramic wares by temper in the South sector sherds.

\begin{tabular}{lllllllll}
\hline Ware & \multicolumn{7}{c}{ Temper Categories } \\
& G & G-H & G-H-B & G-B & B-G & B-H & B & N \\
\hline Plain & 269 & 108 & 8 & 29 & 1 & 3 & 3 & 421 \\
Utility & 232 & 61 & 5 & 17 & - & 3 & 3 & 321 \\
Fine & 46 & 10 & - & 4 & - & - & 2 & 62 \\
Totals & 547 & 179 & 13 & 50 & 1 & 6 & 8 & 804 \\
\hline
\end{tabular}

$\mathrm{G}=$ grog; $\mathrm{G}-\mathrm{H}=$ grog-hematite; $\mathrm{G}-\mathrm{H}-\mathrm{B}=$ grog-hematite-bone; $\mathrm{G}-\mathrm{B}=$ grog-bone; $\mathrm{B}-\mathrm{G}=$ bone-grog; $\mathrm{B}-\mathrm{H}=$ bone-hematite; $\mathrm{B}=$ bone

About 68 percent of the sherds are from grog-tempered vessels, including 64 percent of the plain ware, 72 percent of the utility ware, and 74 percent of the fine ware sherds (see Table 5). Approximately 30 percent of the sherds from the different wares are from vessels tempered with grog and other aplastics, including hematite, burned bone, or mixtures of these tempers. Only 1.7 percent of the sherds are from vessels not tempered with grog; these have either bone or bonehematite tempers in their paste. About 25 percent of the sherds have hematite temper, including 29 percent of the plain ware, 21 percent of the utility ware, and 16 percent of the fine ware. In the case of bone temper in vessel sherds, for the assemblage as a whole, 9.7 percent of the sherds are from vessels with bone temper. This includes 10.2 percent of the plain ware, 8.7 percent of the utility ware, and 9.7 percent of the fine wares (see Table 5). Except for the frequency of bone temper use, the plain ware and utility ware sherds in the assemblage have a coarser paste-with crushed pieces of animal bone and hematite - than do the fine wares; the latter are dominated by finely ground pieces of grog

The 67 rim sherds in the South sector ceramic assemblage includes 14 from plain ware, 37 from utility ware vessels, and 16 from fine ware vessels. If the proportion of rim sherds approximates the frequency of different wares manufactured and in use at the site, then utility wares (mainly jars) are most common, at 55.2 percent, followed by fine wares at 23.9 percent. Plain ware vessel rims comprise 20.9 percent of the rim sherds. No orifice diameters could be determined from the Long site ceramics, but based on a large series of rim orifice measurements on Early Caddo ceramic sherds from the George C. Davis site, utility ware jars have a mean diameter of $23.1 \mathrm{~cm}$, with a range of 11-38 cm, while plain ware bowls, carinated bowls, and jars have a mean diameter of 17.4 $\mathrm{cm}$ (range $9-31 \mathrm{~cm}$ ). Fine ware carinated bowls and bowls have a $22.7 \mathrm{~cm}$ mean orifice diameter (range 9-34 cm) (Perttula 2017:11). Bottles, both plain and engraved, have mean orifice diameters of $6.6-8.0 \mathrm{~cm}$.

The principal utility wares in the South sector have incised (41.7 percent), fingernail punctated (38.4 percent), and incised-punctated (10.3 percent) elements (Table 6). Less common utility wares (each representing less than 2.8 percent of the utility ware assemblage) include brushed, brushed-incised, brushed-punctated, grooved, pinched, cane punctated, circular punctated, and tool punctated. Only the sherds with brushed, brushed-incised, and brushed-punctated decorative elements, accounting for 4.3 percent of the decorated utility wares, are not clearly associated with the Early Caddo period component at the Long site. These are most likely part of the radiocarbondated A.D. 1271-1353 Middle Caddo component better recognized in the North sector (see below). 
Table 6. Decorative methods and elements in the utility ware sherds in the South sector at the Long site.

\begin{tabular}{l}
$\begin{array}{l}\text { Decorative method } \\
\text { and elements }\end{array}$ \\
\hline
\end{tabular}

\section{Brushed}

horizontal brushed marks

overlapping brushed

parallel brushed marks

\section{Brushed-Incised}

opposed brushed-incised marks and lines

parallel brushed-incised marks and lines

\section{Brushed-Punctated}

parallel brushed marks-tool punctated row pushed

through the brushing

\section{Grooved}

parallel grooved lines

\section{Incised}

cross-hatched incised lines

cross-hatched and horizontal incised lines

curvilinear incised line

curvilinear-horizontal incised lines

diagonal incised lines

horizontal incised lines

horizontal-diagonal incised lines

horizontal-diagonal opposed incised lines

horizontal and opposed incised lines

horizontal and vertical incised lines

opposed incised lines

opposed diagonal incised lines

parallel incised lines

straight incised line

triangle incised el.

vertical incised lines

\section{Incised-Punctated}

cross-hatched and horizontal incised lines punctations

horizontal incised panels with crescent-shaped fingernail punctations 
Table 6. Decorative methods and elements in the utility ware sherds in the South sector at the Long site, cont.

Decorative method Rim Body

$\mathrm{N}$ and elements

Incised-Punctated. cont.

horizontal-diagonal incised panel above crescentshaped fingernail punctations

horizontal-diagonal incised panel above finger-

nail punctated rows

horizontal-diagonal incised lines and linear tool punctated zones

incised triangles filled with tool punctations opposed incised lines and circular punctated zone opposed incised lines and tool punctated zone parallel incised lines-fingernail punctated rows parallel incised lines-linear tool punctated row straight incised line-linear tool punctated row straight incised line-single fingernail punctation straight incised line-tool punctated-filled zone

\section{Pinched}

curvilinear pinched ridges

parallel pinched ridges

\begin{tabular}{|c|c|c|}
\hline- & 1 & 1 \\
\hline- & 1 & 1 \\
\hline- & 1 & 1 \\
\hline 2 & - & 2 \\
\hline- & 1 & 1 \\
\hline- & 2 & 2 \\
\hline- & 2 & 2 \\
\hline- & 1 & 1 \\
\hline- & 1 & 1 \\
\hline- & 1 & 1 \\
\hline- & 1 & 1 \\
\hline- & 1 & 1 \\
\hline- & 4 & 4 \\
\hline 1 & 1 & 2 \\
\hline- & 1 & 1 \\
\hline 2 & 6 & 8 \\
\hline- & 1 & 1 \\
\hline- & 36 & 36 \\
\hline- & 51 & 51 \\
\hline- & 1 & 1 \\
\hline- & 26 & 26 \\
\hline- & 2 & 2 \\
\hline- & 5 & 5 \\
\hline- & 1 & 1 \\
\hline 37 & 284 & 321 \\
\hline
\end{tabular}

\section{Punctated, Cane}

cane punctated rows

Punctated, Circular

circular punctated rows

Rim Body N

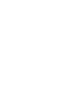


The brushed sherds are from Bullard Brushed jars (Suhm and Jelks 1962:21 and Plate 11). These sherds have brushed or brushed-incised lines oriented in several different ways on the vessel body, most commonly as parallel or vertical brushed marks. One of the Bullard Brushed sherds has a row of tool punctations pushed through the brushing (cf. Suhm and Jelks 1962:21). Brushed sherds in East Texas Caddo ceramic assemblages like that from the Long site are common only after ca. A.D. 1250, beginning in the Middle Caddo period in the Neches River basin, and becoming the predominant utility ware in post-A.D. 1400 Late Caddo period assemblages (see Perttula 2013).

The one grooved sherd in the utility ware assemblage has parallel grooved ridges (see Table 6). Although not common here or in other Early Caddo period contexts, for example comprising only 1.3 percent of the more than 11,000 identified sherds at the George C. Davis site (Newell and Krieger 1949:Table 13), Krieger (in Newell and Krieger 1949:12) noted that "it is possible that these constitute a distinct minor type at the Davis site." It is known that grooved vessels of Early Caddo period age have been recovered in Early Caddo period burial features at the Crenshaw site (3MI6) on the Red River in Southwest Arkansas (Perttula 2017:55), where they have been called Crenshaw Fluted; they are not known in any other part of the Caddo area. Petrographic data obtained by Robinson (2017:34-35) on grooved sherds from the George C. Davis site suggests that they are from vessels made by Caddo potters in the Great Bend region of Southwest Arkansas, and traded/exchanged several hundred miles to the southwest with East Texas Caddo communities in the Neches River basin.

Only a few rim and body sherds in the South sector can be identified as being from Crockett Curvilinear Incised ( $n=5)$ or Pennington Punctated-Incised ( $n=3)$ vessels. The Crockett Curvilinear Incised sherds include a rim with horizontal and curvilinear incised lines with a tool punctatedfilled circle element (Figure 14a), a body sherd with a curvilinear incised zone filled with small

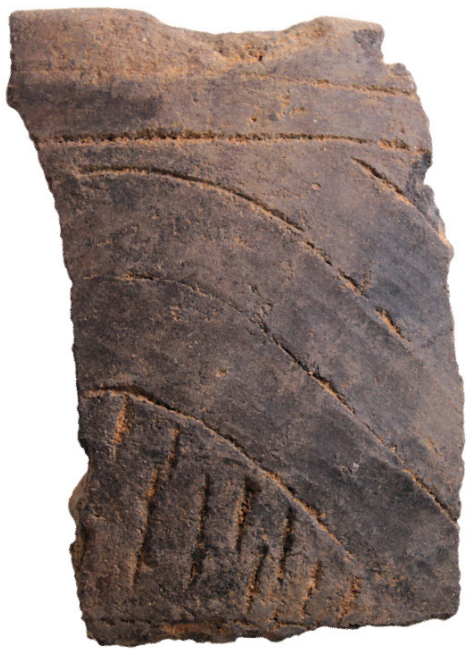

a

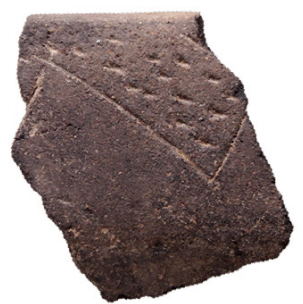

b

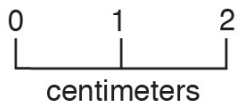

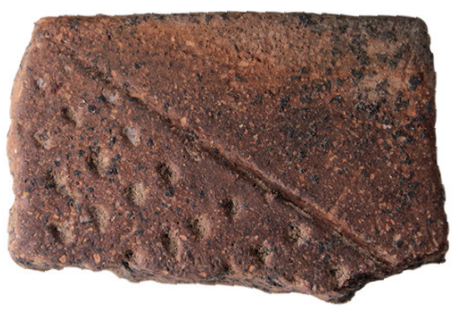

C

Figure 14. Crockett Curvilinear Incised and Pennington Punctated-Incised sherds in the South sector at the Long site: a, Crockett Curvilinear Incised rim sherd, ST 129, 20-40 cm; b, Pennington Punctated-Incised rim sherd, ST 124, 0-20 cm; c, Pennington Punctated-Incised rim sherd, ST 101, 0-20 cm. 
cane punctations, two body sherds with curvilinear and curvilinear-horizontal incised lines, and a body sherd with opposed incised lines and a circular punctated zone. The Pennington PunctatedIncised sherds (Figure 14b-c) include two rim sherds with incised triangle elements filled with tool punctations and a body sherd with opposed incised lines and a tool punctated zone (see Table 6).

Davis Incised sherds at the Long site have horizontal incised lines that encircle the rim (see Table 6; see also Suhm and Jelks 1962:35 and Plate 18), and occasionally the incised lines overhang (Figure 15a-e). None of these sherds have impressed triangle elements below the bottom incised line, indicating they are not from Coles Creek Incised vessels, and also suggesting they likely were made and used after ca. A.D. 1000-1050. One of the Davis Incised rim sherds has rim peaks (see Suhm and Jelks 1962:Plate 18f).

Dunkin Incised is the most common identified utility ware type at the Long site, with 34 rim and body sherds (see Table 6; see also Suhm and Jelks 1962:37 and Plate 19). These sherds include geometric elements with cross-hatched, cross-hatched and horizontal incised lines, diagonal lines, horizontal-diagonal lines, horizontal-diagonal opposed lines, horizontal-opposed lines, opposed, opposed diagonal lines, and a rim sherd with a triangle incised element (Figure 16a-b). A few sherds with vertical and horizontal and vertical incised lines (see Table 6) may be from Dunkin Incised (see Suhm and Jelks 1962:Plate 19d) or Kiam Incised (see Suhm and Jelks 1962:89 and Plate 45a, d) vessels, or less likely from Weches Fingernail Impressed vessels (see Suhm and Jelks 1962:Plate 77b-c).

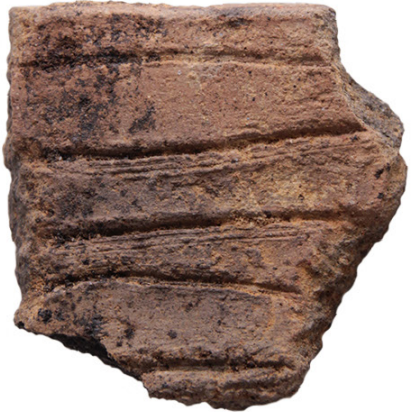

a

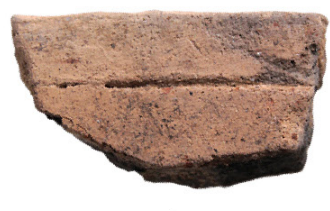

b

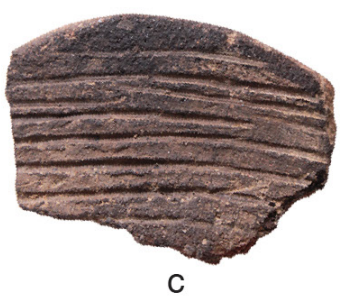

C

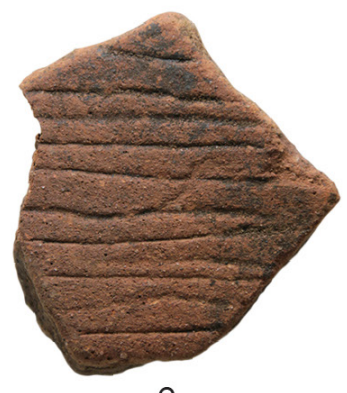

e

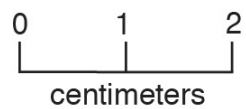

Figure 15. Davis Incised rim and body sherds in the South sector at the Long site: a, ST 126, 20-40 cm; b, ST 38, 0-20 cm; c, ST 49, 20-40 cm; d, ST 103, 20-40 cm; e, ST 37, 20-40 cm. 


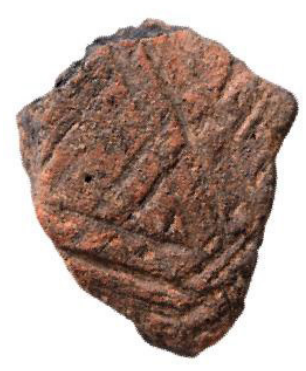

a

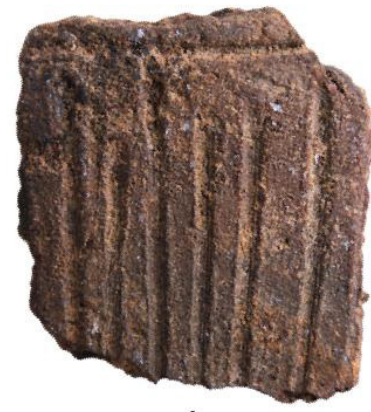

b

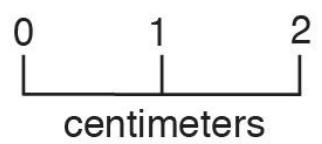

Figure 16. Dunkin Incised body sherds in the South sector at the Long site: a, ST 138, 20-40 cm; b, ST 135, 0-20 cm.

Sherds $(n=25)$ from Weches Fingernail Impressed vessels are also a common Early Caddo utility ware at the Long site. These are from Weches Fingernail Impressed, var. Weches vessels (Stokes and Woodring 1981:184-185 and Figures 22n-q and 23a). They have horizontal incised panels on the rim of jars with crescent-shaped punctations between the incised lines (Figure 17a-f)

One of the incised-punctated sherds in the Long site assemblage has an upper cross-hatched incised decorative (on the rim) element, followed by two closely-spaced horizontal incised lines at the rim-body juncture, and with rows of fingernail punctations on the body (Figure 18a). The cross-hatched incised lines on this sherd suggests it is from a Dunkin Incised vessel (see Suhm and Jelks 1962:Plate 19i) that has fingernail punctations covering the vessel body (see Suhm and Jelks 1962:Plate 19g).

The few sherds with pinched decorative elements from the Long site $(n=5)$ are from Hollyknowe Ridge Pinched vessels (see Webb and McKinney 1975:84 and Figure 10v-z), an Early Caddo period utility ware. The sherds from the site have curvilinear or parallel (vertical) ridges formed by closelyspaced fingernail punctations (see Figure 18b-c), sometimes accompanied by incised lines.

Punctated utility ware sherds comprise 41.8 percent of the utility ware sherd sample from the Long site (see Table 6), with fingernail punctated sherds (Figure 19a-e) outnumbering all the other punctated decorative elements (i.e., cane, circular, and tool) by a 11.2:1 ratio. Most of the fingernail punctated sherds are likely to be from Wilkinson Punctated vessels with unzoned rows of punctations (Webb and McKinney 1975:82 and Figure 10t-u; Girard et al. 2020), but others may come from Kiam Incised jars (see Suhm and Jelks 1962:Plate 45b-c, e). The cane (Figure 19g), circular tool, and triangular or pointed tool (Figure 19f) punctated sherds may be from Evansville Punctated vessels (Webb and McKinney 1975:84 and Figure 10p-s).

The fine ware sherds in the South sector include a few engraved-punctated (1.6 percent) bowl and red-slipped (8.1 percent) bottle sherds, but more than 90 percent of the fine ware sherds are from carinated bowls, bowls, and bottles that have engraved and/or excised lines and elements (Table 7). Where the types of engraved fine ware can be identified, they include Holly Fine Engraved, Hickory 


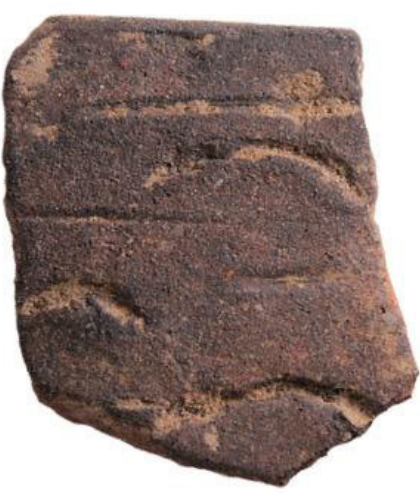

a

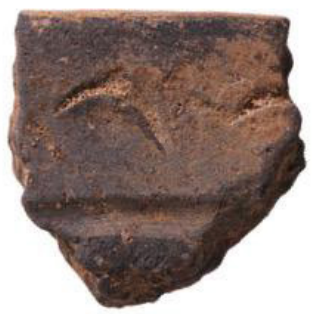

d

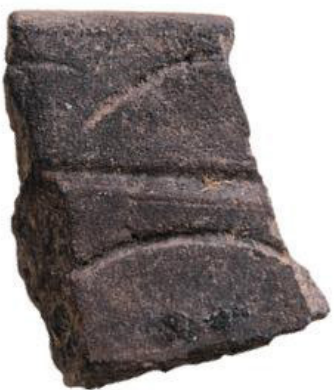

b

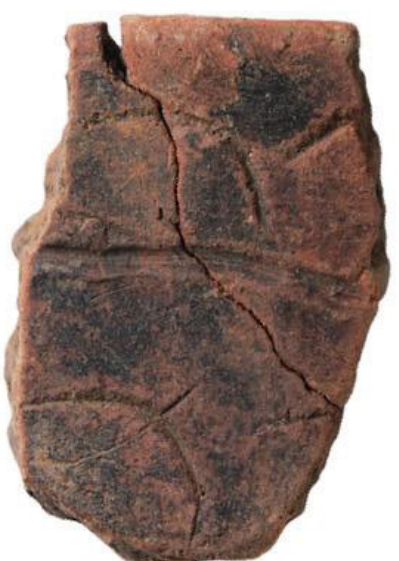

C
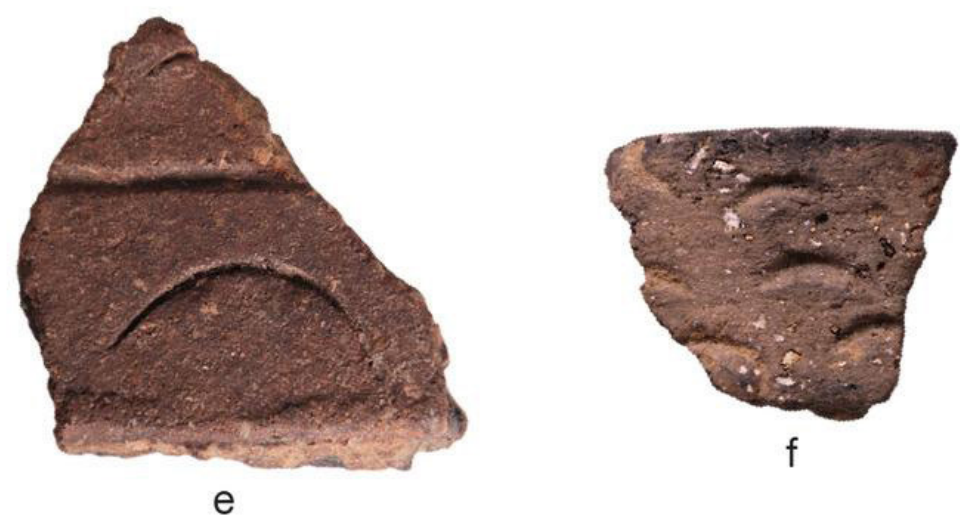

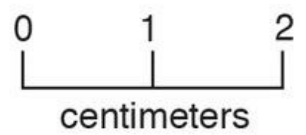

Figure 17. Weches Fingernail Impressed rim sherds from the South sector at the Long site: a, ST 19, 20-40 cm; b, ST 123, 0-20 cm; c, ST 18, 0-20 cm; d, ST 39, 20-40 cm; e, ST 21, 40-60 cm; f, ST 119, 20-40 cm.

Engraved, and Spiro Engraved. Two (3.6 percent) of the engraved fine ware sherds, both from Holly Fine Engraved vessels, have a red ochre-rich clay pigment rubbed in the engraved lines; Suhm and Jelks (1962:79) note that "red pigment is common in lines and excised areas; no other colors noted."

The culturally most diagnostic engraved fine ware in the South sector at the Long site is Holly Fine Engraved; there are 33 rim and body sherds in the assemblage (see Table 7), almost all apparently from carinated bowls. Rim sherds on Holly Fine Engraved vessels at the site have closely-spaced vertical-diagonal lines, concentric semi-circular lines, excised triangle elements, hatched triangle elements, horizontal-diagonal lines around an excised triangle element, and horizontal-vertical engraved lines (Figure 20a-e). Body sherds also have curvilinear opposed engraved lines, excised semi-circles, horizontal-diagonal lines, horizontal-vertical engraved lines next to an excised triangle element, open pendant triangles, opposed engraved lines, opposed diagonal engraved lines next to an excised triangle element, and fine line parallel engraved lines 


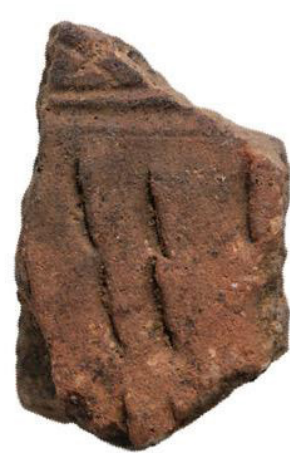

a

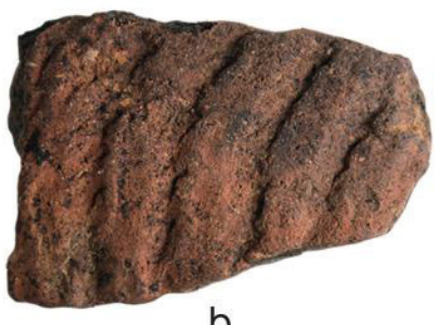

b

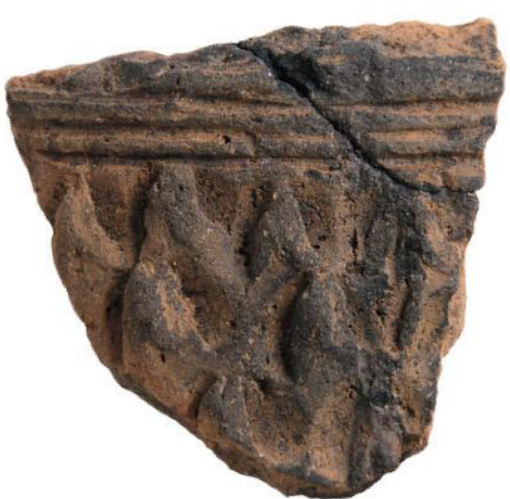

C

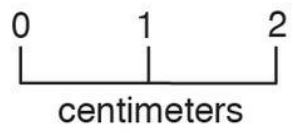

Figure 18. Incised-punctated and pinched sherds in the South sector at the Long site: a, incised-punctated body sherd, ST 106, 20-40 cm; b, pinched body sherd, ST 42, 20-40 cm; c, incised-pinched body sherd, ST 11, 0-20 cm.

(Figure 20f-h). Two Holly Fine Engraved body sherds have a red clay pigment rubbed in the engraved lines (see Table 7).

Sherds from Holly Fine Engraved vessels occur in three different spatial clusters in the South sector (Figure 21), indicating that this distinctive Early Caddo period fine ware was in broad use in domestic contexts at the Long site. These spatial clusters overlap with each of the four high density sherd clusters (see Figure 13) as well as the three high artifact density clusters (see Figure 11).

Hickory Engraved (see Suhm and Jelks 1962:71 and Plate 36) is also a common fine ware type at the Long site (see Table 7). These sherds have horizontal engraved lines on the bodies of bottles as well as horizontal lines that encircle the rim of bowls (Figure 22a).

Two rim sherds from the Long site have engraved panels with cross-hatched engraved lines (see Figure 22b-c). Stokes and Woodring (1981:166 and Figure 20f) include such sherds as a Hickory Engraved pattern at the George C. Davis site, and describe it as "simple engraved, band designs on vessel rims...cross-hatched diagonal lines... being present only on bowls."

One body sherd in the site assemblage has been classified as Spiro Engraved. It is horizontalopposed diagonal engraved lines and a zone of excised punctations (see Figure 22d). Suhm and Jelks (1962:147 and Plate 74b, f, i) note that "fine punctations appear in circles and corners of the designs" on both bottles, bowls, and beakers.

Engraved sherds that are not identifiable to a currently defined fine ware type have simple curvilinear or geometric elements (see Table 7). The latter include cross-hatched circular elements, opposed engraved lines and a cross-hatched zone, parallel lines, and straight engraved or excised lines. 

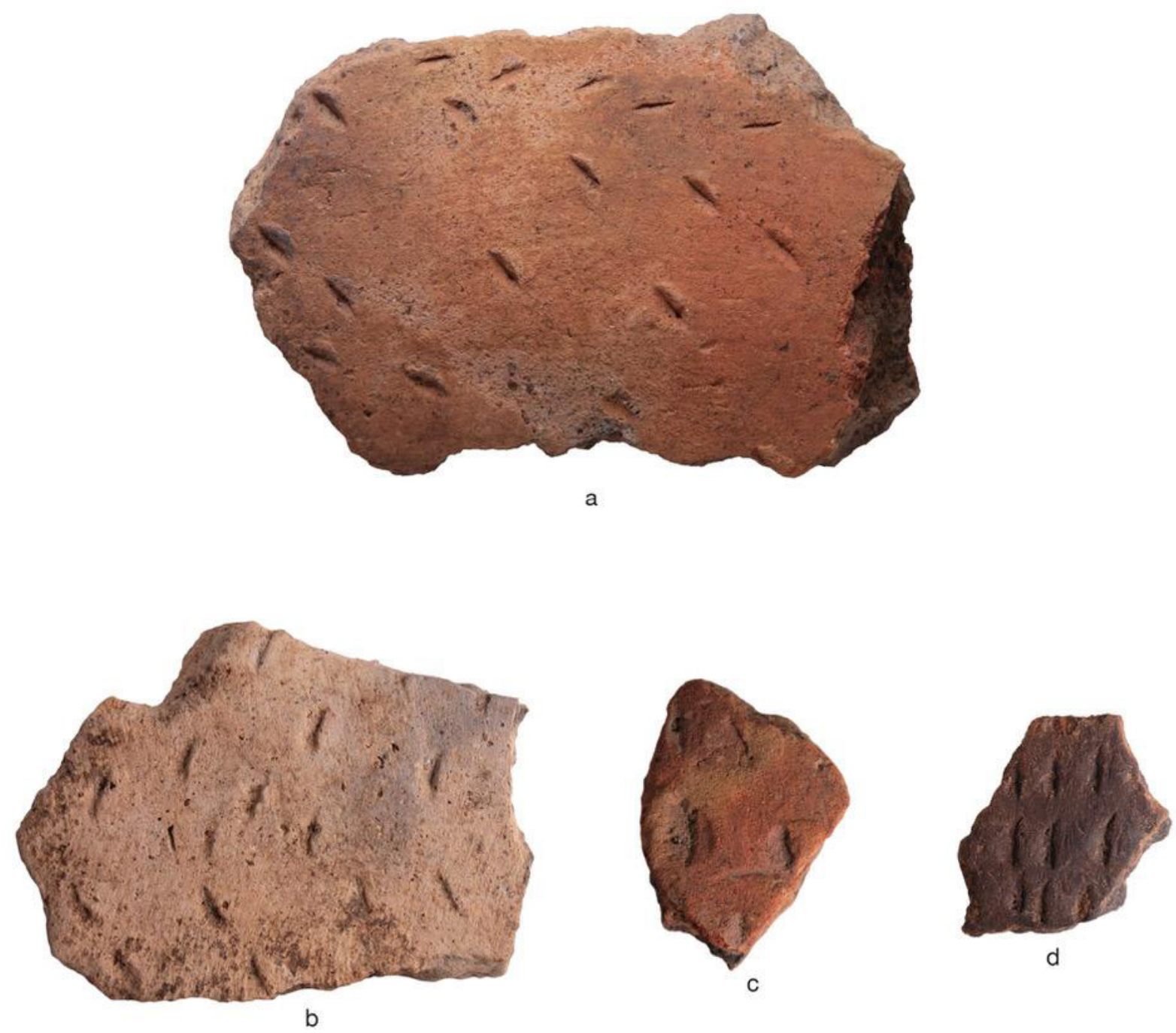

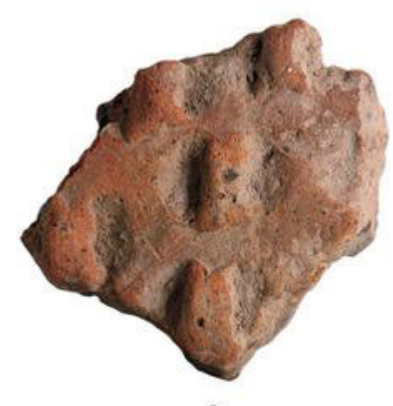

e

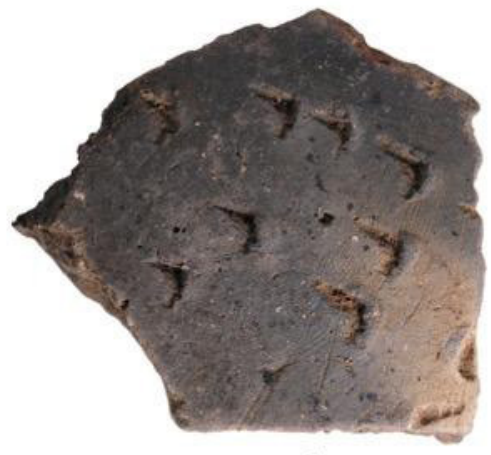

f

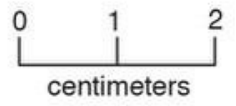


Table 7. Decorative methods and elements in the fine ware sherds in the South sector at the Long site.

\begin{tabular}{|c|c|c|c|}
\hline $\begin{array}{l}\text { Decorative method } \\
\text { and elements (type identifications) }\end{array}$ & $\operatorname{Rim}$ & Body & $\mathrm{N}$ \\
\hline \multicolumn{4}{|l|}{ Engraved } \\
\hline $\begin{array}{l}\text { closely-spaced vertical-diagonal engraved } \\
\text { lines (Holly) }\end{array}$ & 1 & - & 1 \\
\hline concentric semi-circular lines (Holly) & 2 & 1 & 3 \\
\hline cross-hatched engraved panel (Hickory) & 2 & - & 2 \\
\hline cross-hatched circular el. & - & 1 & 1 \\
\hline curvilinear engraved lines & - & 3 & 3 \\
\hline curvilinear opposed engraved lines (Holly) & - & 1 & 1 \\
\hline curvilinear-straight engraved lines & - & 1 & 1 \\
\hline diagonal engraved lines (Holly) & - & $1 *$ & 1 \\
\hline excised semi-circle (Holly) & - & 1 & 1 \\
\hline excised triangle el. (Holly) & 3 & 1 & 4 \\
\hline hatched triangle el. (Holly) & 1 & - & 1 \\
\hline horizontal engraved lines (Hickory) & 4 & 4 & 8 \\
\hline horizontal-diagonal engraved lines (Holly) & - & 1 & 1 \\
\hline $\begin{array}{l}\text { horizontal-diagonal engraved lines-excised } \\
\text { triangle el. (Holly) }\end{array}$ & 1 & - & 1 \\
\hline horizontal-vertical engraved lines (Holly) & 1 & 2 & 3 \\
\hline $\begin{array}{l}\text { horizontal-vertical engraved lines-excised } \\
\text { triangle el. (Holly) }\end{array}$ & - & $1 *$ & 1 \\
\hline open pendant triangle (Holly) & - & 2 & 2 \\
\hline opposed diagonal engraved lines-excised triangle (Holly) & - & 1 & 1 \\
\hline opposed engraved lines (Holly) & - & 3 & 3 \\
\hline opposed engraved lines and cross-hatched zone & - & 1 & 1 \\
\hline parallel engraved lines & - & 7 & 7 \\
\hline parallel engraved lines, fine line (Holly) & - & 1 & 1 \\
\hline straight engraved line & - & 5 & 5 \\
\hline straight excised line & - & 2 & 2 \\
\hline vertical engraved lines (Holly) & - & 1 & 1 \\
\hline \multicolumn{4}{|l|}{ Engraved-punctated } \\
\hline $\begin{array}{l}\text { horizontal-opposed diagonal engraved lines and } \\
\text { zone of excised punctations (Spiro) }\end{array}$ & 1 & - & 1 \\
\hline \multicolumn{4}{|l|}{ Red-slipped } \\
\hline ext. red-slipped & - & 5 & 5 \\
\hline Totals & 16 & 46 & 62 \\
\hline
\end{tabular}

*sherd with a red pigment 

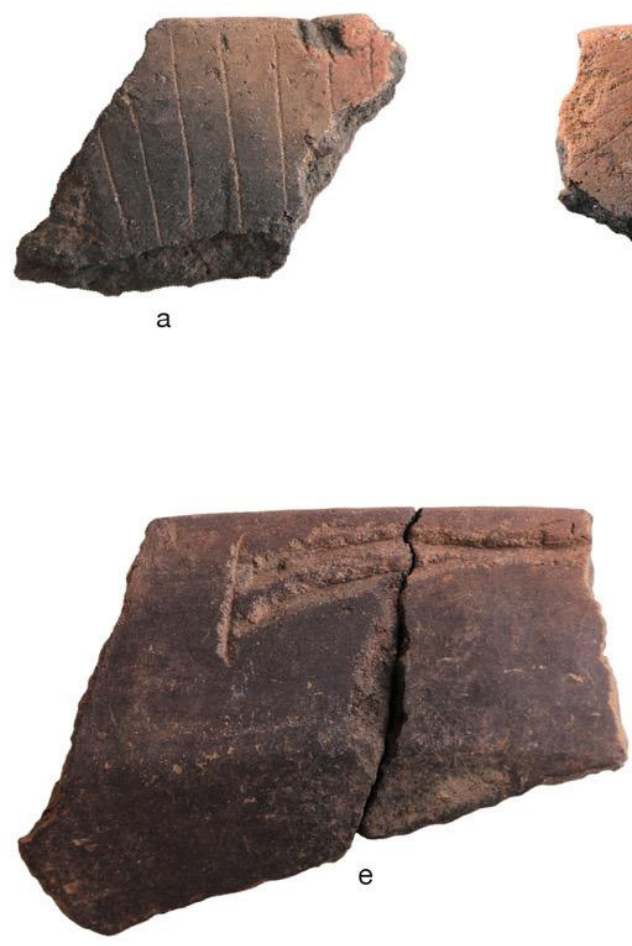

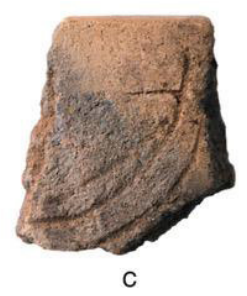

b
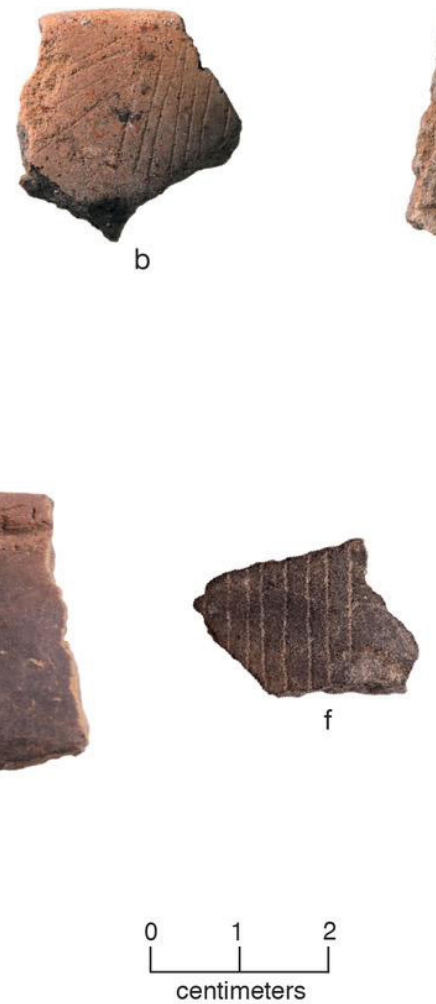
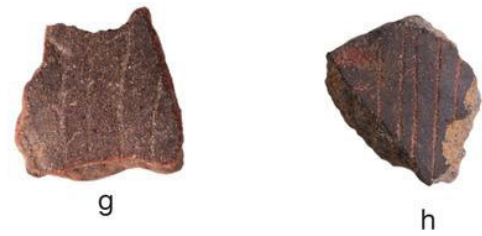

Figure 20. Holly Fine Engraved rim and body sherds in the South sector at the Long site: a, ST 146, 40-60 cm; b, ST 106, 20-40 cm; c, ST 130, 0-20 cm; d, ST 113, 20-40 cm; e, ST 129, 0-20 cm; f, ST 146, 0-20 cm; g, ST 33, 20-40 cm.

In the decorated ceramic sherd assemblage from the 1979-1980 excavations at the George C. Davis mound center and village, red-slipped sherds comprise 6.1 percent of the fine wares (Stokes and Woodring 1981). At the Long site, red-slipped bottle sherds (see Figure 22e) in the South sector account for a comparable 8.1 percent (see Table 7). Red-slipped ceramic vessel sherds are a particularly characteristic part of a number of later Middle Caddo period assemblages in the Sabine, Big Cypress, and Red River basins, but not notably so in the Neches River basin (see Perttula 2013).

Other distinctive ancestral Caddo ceramic sherds from the South sector include two rim sherds (Figure 23a-b) and a ceramic handle (Figure 23c). One rim sherd with a horizontal engraved line below the lip, has a very broad and flat lip (15 mm thick), and may be from a plate or platter, while the other has diagonal engraved lines on the lip itself. This resembles the diagonal "grooves across the thickened lip and into the interior of a vessel [giving] a rope-like effect" (Suhm and Jelks 1962:77 and Plate 39d) on certain Holly Fine Engraved vessels. There is also a single plain ceramic handle sherd from a grog-hematite-bone-tempered vessel (likely a jar) in the assemblage.

In addition to the tempered Caddo ceramic wares from the South sector, a few sherds have only a sandy paste. These sherds are Goose Creek Woodland period wares (see Newell and Krieger 1949:130-131; Stokes and Woodring 1981:154-155; Suhm and Jelks 1962:Plates 28-29; Perttula 2018). These include a Goose Creek Incised rim sherd with a direct profile and a rounded lip (Figure 24b), two Goose Creek Incised-Punctated sherds (Figure 24a, c) with zones of tool punctations, a Goose Creek Incised body sherd with parallel incised lines (ST 24, 40-60 cm bs), and three Goose Creek Plain body sherds (ST 23, 40-60 cm bs, ST 116, 40-60 cm bs, and ST 143, 20-40 cm bs). The 


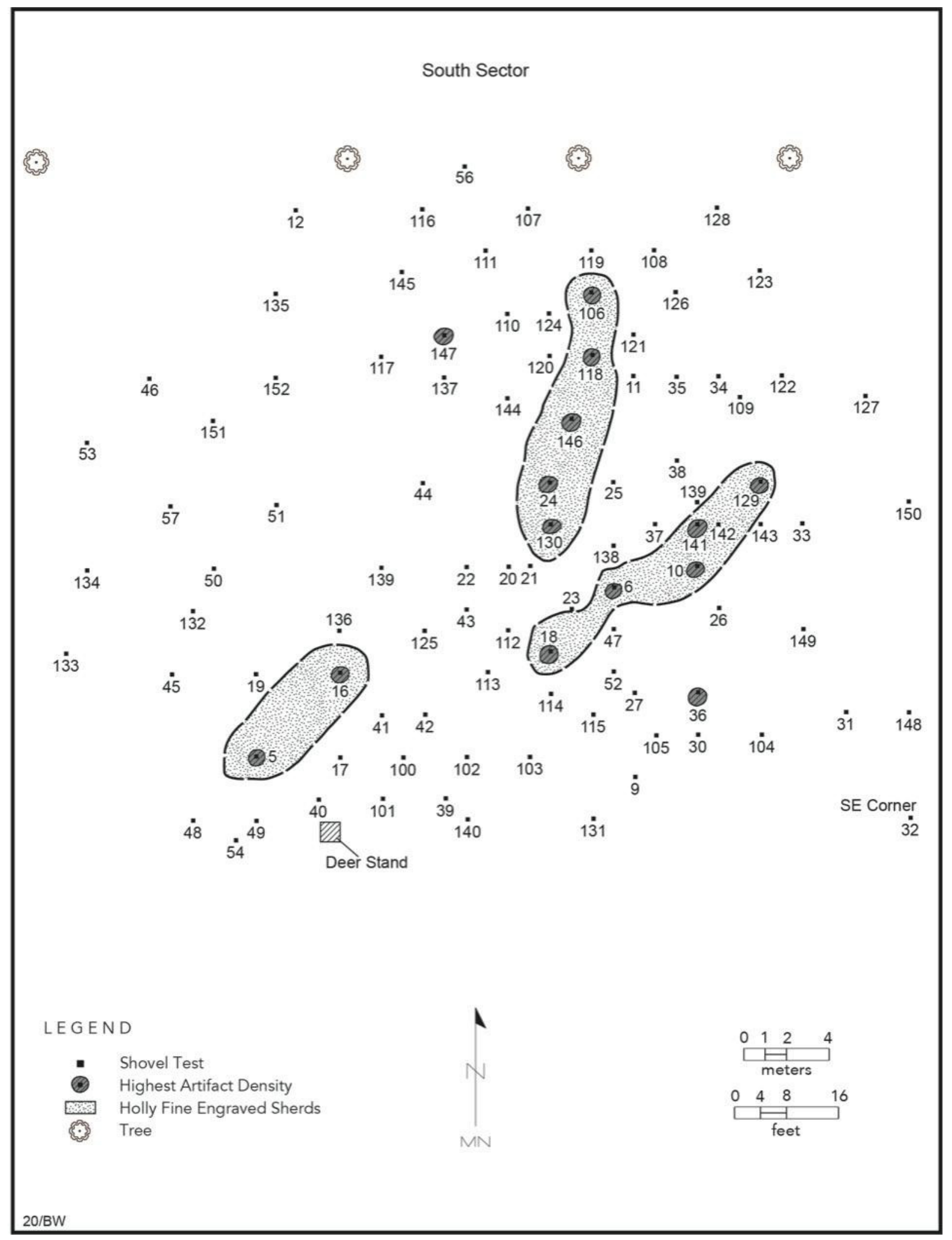

Figure 21. Spatial distribution of Holly Fine Engraved sherds in South sector shovel tests. 


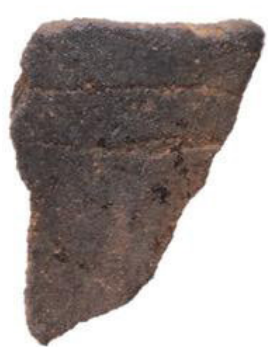

a

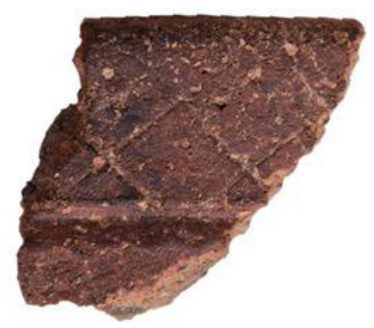

b

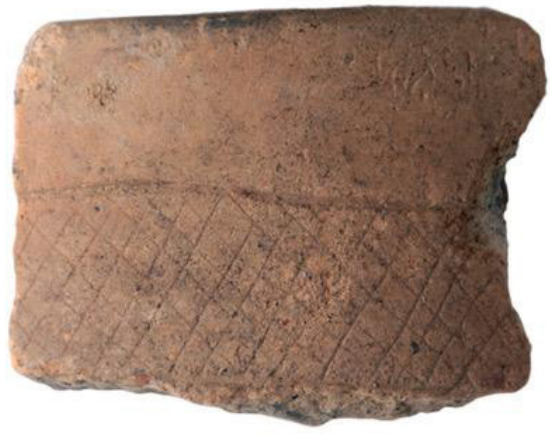

C
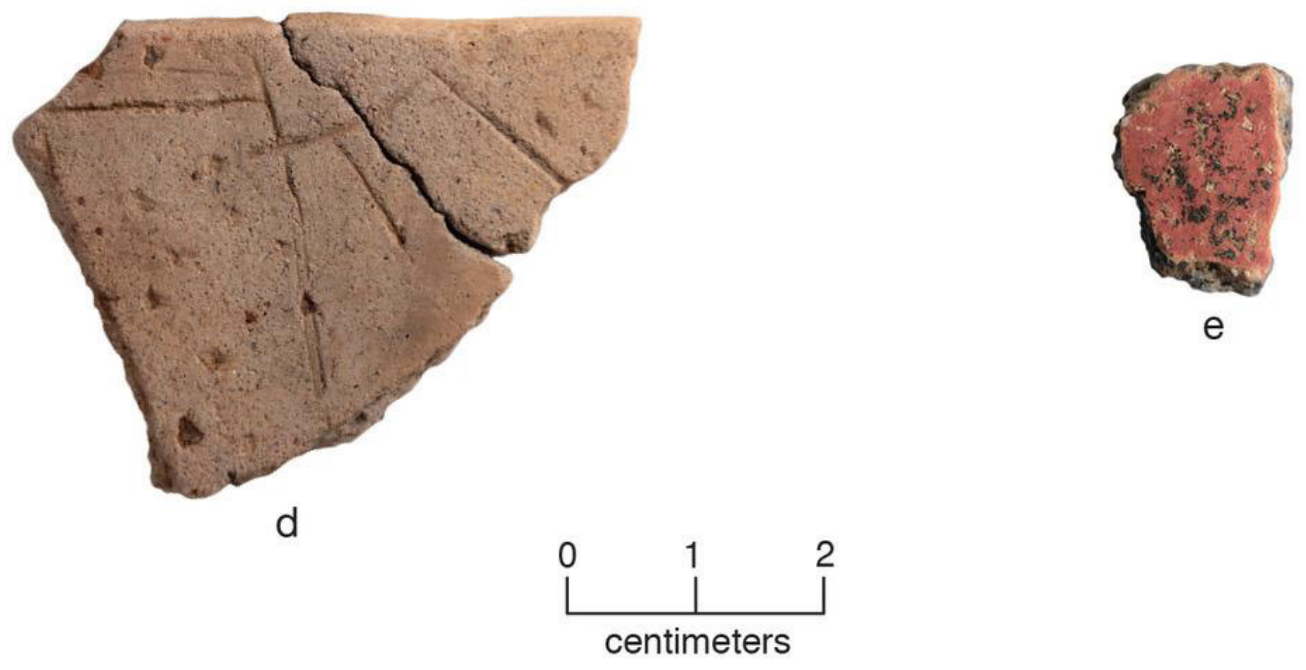

Figure 22. Other fine ware sherds in the South sector at the Long site: a, Hickory Engraved rim sherd, ST 114, 40-54 cm; b, cross-hatched engraved rim sherd, ST 21, 40-60 cm; c, cross-hatched engraved zone rim sherd, ST 39, 0-20 cm; d, Spiro Engraved, engraved zoned punctated body sherd, ST 112, 20-40 cm; e, red-slipped body sherd, ST $21,0-20 \mathrm{~cm}$.

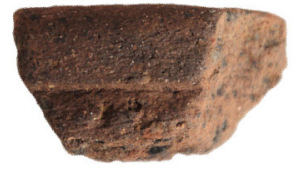

a

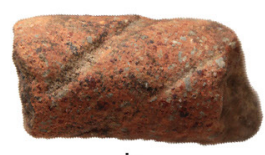

b
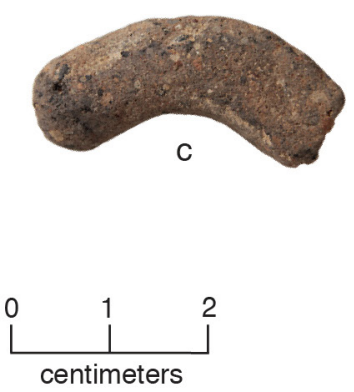

Figure 23. Miscellaneous ceramic sherds in the South sector at the Long site: a, very thick and flat rim, probably from a plate or platter, ST 121, 20-40 cm; b, rim sherd with diagonal engraved lines on the lip, ST 42, 0-20 cm; c, ceramic handle, ST 19, 40-56 cm; d, Red River long-stemmed pipe sherd, ST 106, 0-20 cm. 


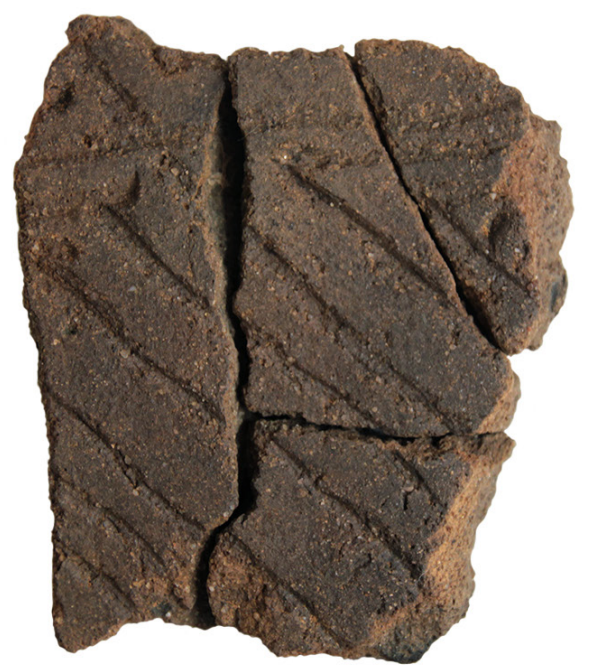

a

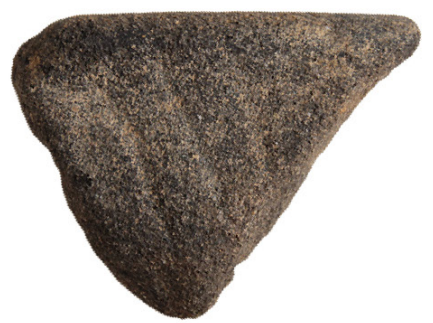

b

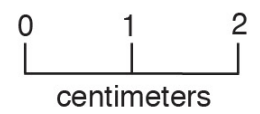

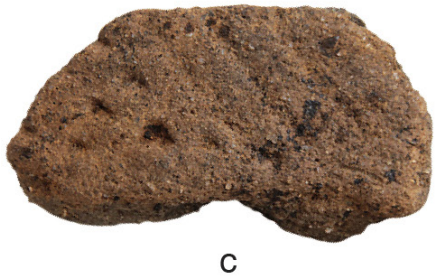

C

Figure 24. Sandy paste decorated sherds from the South sector at the Long site: a, opposed incised lines and punctated zone on conjoined body sherds, ST 102, 20-40 cm bs; b, opposed incised lines on rim sherd, ST 121, 40-60 cm; c, zoned incised-punctated body sherd, ST 126, $20-40 \mathrm{~cm}$.

relative frequency of decorated sandy paste sherds in the South sector suggests these sherds are from a late Woodland period use of the site, perhaps during the $7^{\text {th }}-8^{\text {th }}$ century A.D. based on dated Woodland period components in the Angelina River basin (Perttula 2008).

In the North sector, the distribution of ceramic sherds closely matches the overall density of prehistoric artifacts in the sector (Figure 25). Approximately 65 percent of the sherds are plain ware, followed by 27 percent from utility ware vessels, and 8 percent from fine ware vessels (Table 8). The plain to decorated sherd ratio in the assemblage is 1.83 .

Table 8. Ceramic wares by temper in the North sector sherds at the Long site.

\begin{tabular}{|c|c|c|c|c|c|c|c|}
\hline \multirow[t]{2}{*}{ Ware } & \multicolumn{7}{|c|}{ Temper Categories } \\
\hline & $\mathrm{G}$ & G-H & G-H-B & G-B & $B-G$ & $\mathrm{H}$ & $\mathrm{N}$ \\
\hline Plain & 18 & 9 & 3 & 2 & 1 & - & 33 \\
\hline Utility & 9 & 3 & - & 1 & - & 1 & 14 \\
\hline Fine & 3 & - & - & 1 & - & - & 4 \\
\hline Totals & 30 & 12 & 3 & 4 & 1 & 1 & 51 \\
\hline
\end{tabular}

$\mathrm{G}=$ grog; $\mathrm{G}-\mathrm{H}=$ grog-hematite; $\mathrm{G}-\mathrm{H}-\mathrm{B}=$ grog-hematite-bone; $\mathrm{G}-\mathrm{B}=$ grog-bone; $\mathrm{B}-\mathrm{G}=$ =bone-grog; $\mathrm{H}=$ hematite 


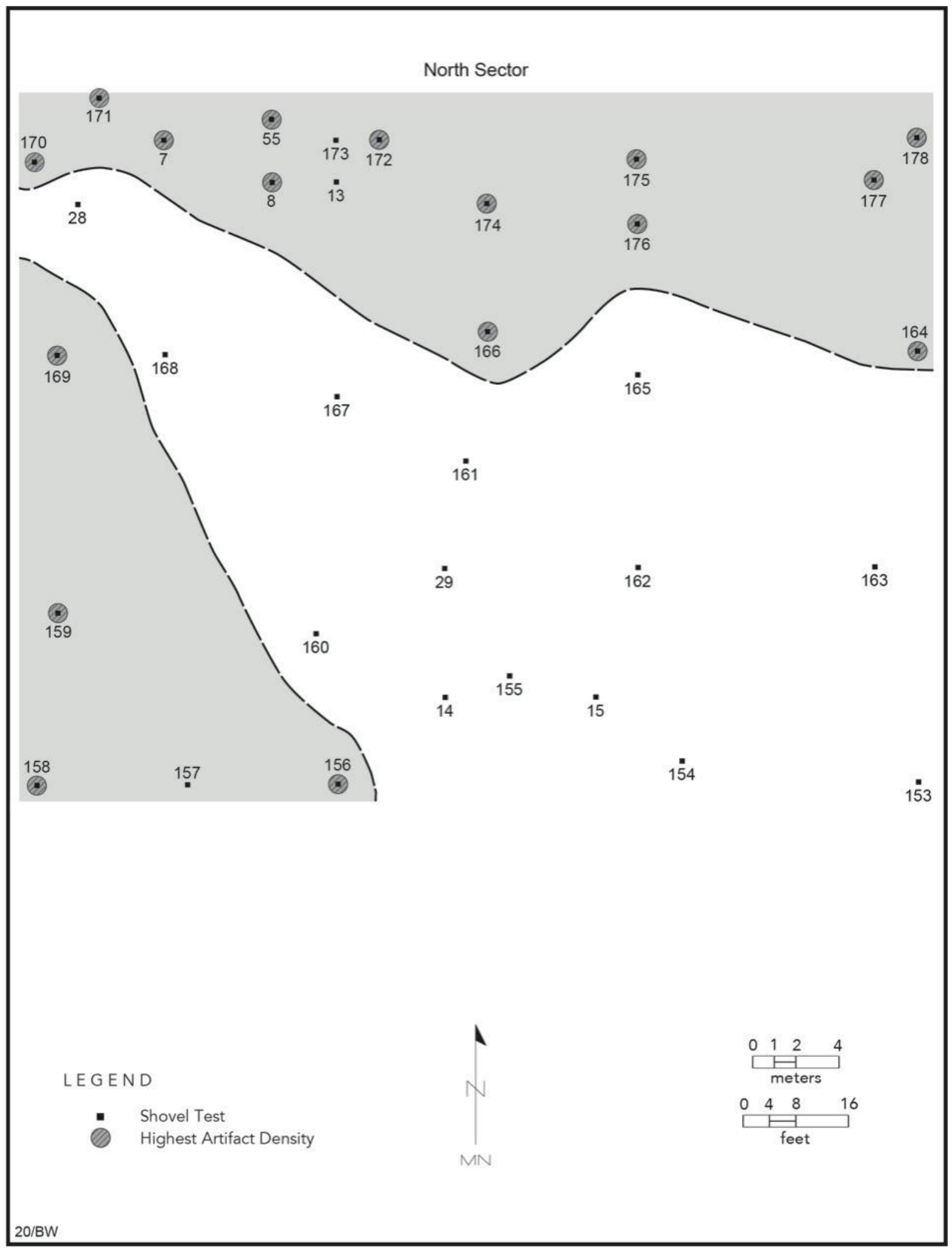

Figure 25. Distribution of shovel tests with ancestral Caddo ceramic sherds in the North sector of the Long site. 
About 98 percent of the North sector ceramic sherds are tempered with grog, either as the sole temper, or in combination with hematite and burned bone. Grog temper is most common in the fine wares, as is grog-bone-temper (see Table 8). Grog-hematite-tempered pastes are prevalent in the plain ware and utility ware. Hematite is present as an aplastic in 31 percent of the North sector sherds compared to 15 percent that have burned bone temper.

The most distinctive aspect of the decorated sherds from the North sector is the proportion of sherds (39 percent of the decorated sherds and 50 percent of the utility ware sherds) that have brushing marks, either as the sole decorative element or in combination with appliqued or incised elements (Table 9 and Figure 26a-b). These sherds are from a radiocarbon-dated A.D. 1271-1353 component in the northwestern part of the North sector (Figure 27), and they likely are from Bullard Brushed vessels (see Suhm and Jelks 1962:21 and Plate 11).

Table 9. Decorative methods and elements in the North sector ceramic vessel sherds.

\begin{tabular}{l}
$\begin{array}{l}\text { Decorative method } \\
\text { and elements }\end{array}$ \\
\hline
\end{tabular}

\title{
Utility Ware
}

\section{Brushed}

opposed brushed marks

parallel brushed marks

\section{Brushed-Appliqued}

parallel brushed marks-straight appliqued fillet

\section{Brushed-Incised}

opposed brushed-incised marks and lines parallel brushed-incised marks and lines

\section{Incised}

closely-spaced parallel lines

parallel incised lines

straight incised line

\section{Punctated}

linear tool punctated rows

$\begin{array}{lll}- & 1 & 1 \\ - & 1 & 1 \\ - & & 1 \\ & 1 & \\ - & & 1 \\ - & 1 & 3 \\ & 3 & 1 \\ - & & 1 \\ - & 1 & 2 \\ - & 1 & \end{array}$

1

1

\author{
1
}

1

3

1

Fine Ware

Engraved

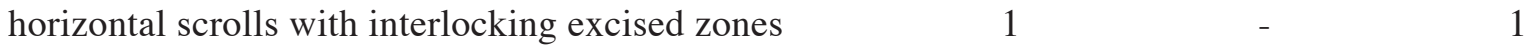

horizontal-vertical engraved lines

opposed engraved lines

straight engraved line

$\begin{array}{lll}- & 3 & 3\end{array}$

Totals

1

17 


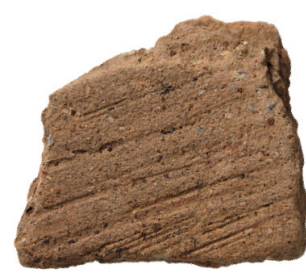

a

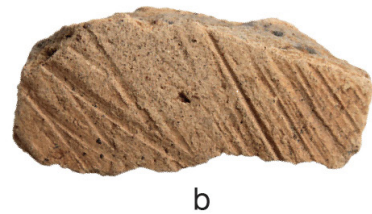

$b$
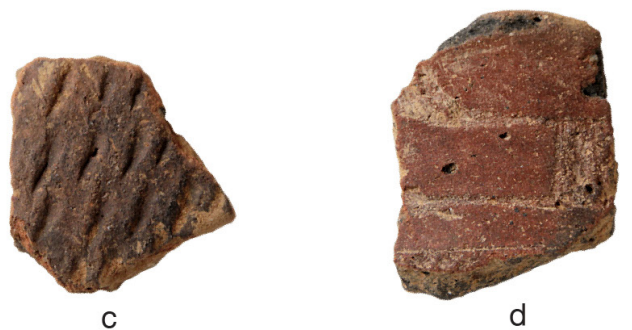

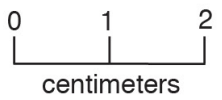

Figure 26. Selected decorated sherds in the North sector at the Long site; a, brushed-incised, ST 170, 20-40 cm bs; b, brushed-incised, ST 172, 0-20 cm bs; c, linear tool punctated, ST 8, 40$60 \mathrm{~cm}$ bs; d, Washington Square Paneled rim sherd, ST 7, 40-60 cm bs.

The other utility wares in the North sector have either incised or linear tool punctated elements (see Table 9 and Figure 26c). The incised body sherds are not identifiable to type, but the body sherds with linear rows of tool punctations may be from Sinner Linear Punctated vessels (see Suhm and Jelks 1962:143 and Plate 72). This is a Middle Caddo period utility ware (see Girard et al.2020).

One of the engraved sherds in the northwestern part of the North sector (see Figure 26d) is from a Washington Square Paneled vessel; sherds and vessels of this Middle Caddo period type have been identified at ancestral Caddo sites in the Angelina and mid-Sabine River basins, and the type was defined by Hart (1982:71-73 and Figure 3-12,2014). The type occurs on carinated bowls with rectilinear engraved or incised panels, including interlocking horizontal scrolls with hatched or punctated brackets as well as punctated rows at the top and bottom of the panels (Perttula and Selden 2014:Figure 23a-b). The other engraved sherds have horizontal-vertical engraved lines, and may be from a Holly Fine Engraved vessel, opposed engraved lines, or a straight engraved line (see Table 9).

\section{Ceramic Pipe Sherds}

A single bone-hematite-tempered long-stemmed Red River pipe stem (see Figure 23d) was recovered in ST 106, 0-20 cm bs, in the northern part of the South sector. The stem diameter is 9.0 $\mathrm{mm}$, and the hole diameter is $6.2 \mathrm{~mm}$. These size measurements suggest that this pipe stem sherd is from the Early Caddo period Graves Chapel variety of Red River pipe, as they have stem diameters between 7-12 $\mathrm{mm}$, with an average of $10 \mathrm{~mm}$, and have 4-6.5 $\mathrm{mm}$ stem hole diameters (Hoffman 1967:9).

\section{Burned Clay}

Only 16 pieces of burned clay were recovered in the shovel tests in the South sector (Table 10). These pieces likely represent oxidized clay remnants of hearths or earth ovens. The burned clay pieces are primarily found within two principal north and south areas (Figure 28) that also have high artifact densities and high ceramic vessel sherd densities (see Figures 11 and 13). 


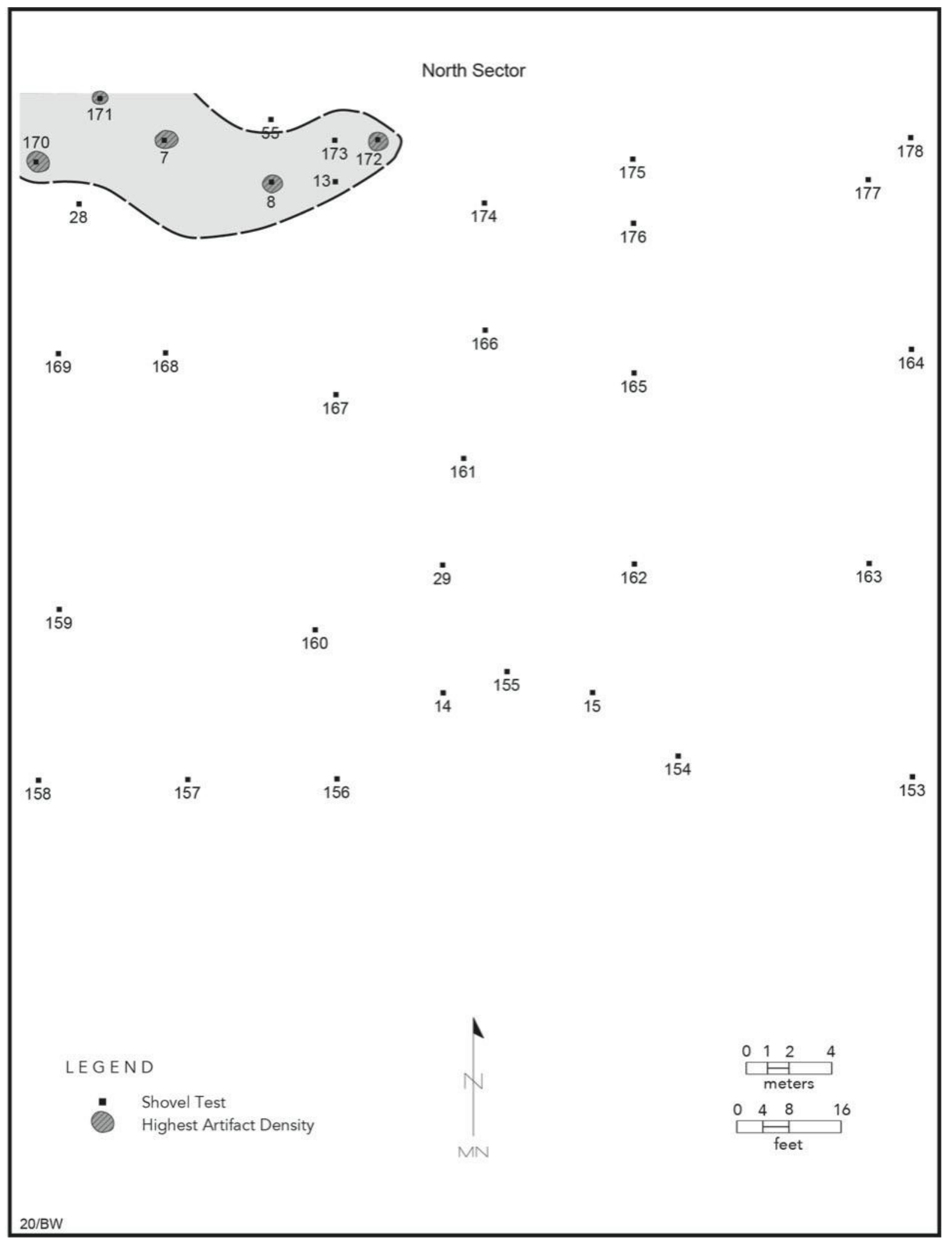

Figure 27. Distribution of post-A.D. 1200 Middle Caddo period ceramic sherds in North sector shovel tests. 
Table 10. Burned clay in the South sector.

\begin{tabular}{ll}
\hline ST and depth & No. of Burned clay pieces \\
\hline ST $18,0-20 \mathrm{~cm}$ & 2 pieces of burned clay \\
ST 22, 20-40 cm & 1 piece of burned clay \\
ST $23,40-60 \mathrm{~cm}$ & 1 piece of burned clay \\
ST $42,0-20 \mathrm{~cm}$ & 3 pieces of burned clay \\
ST $102,20-40 \mathrm{~cm}$ & 5 pieces of burned clay \\
ST $103,20-40 \mathrm{~cm}$ & 1 piece of burned clay \\
ST $106,20-40 \mathrm{~cm}$ & 1 piece of burned clay \\
ST $120,40-60 \mathrm{~cm}$ & 1 piece of burned clay \\
ST $141,0-20 \mathrm{~cm}$ & 1 piece of burned clay \\
\hline
\end{tabular}

\section{Arrow Points}

There are 16 arrow points and arrow point fragments in the South sector shovel tests (Table 11). Seven of these are Early Caddo Alba points (Figure 29a-e) with straight stems, flat bases, and serrated blades, and two others are Alba point preforms. The Alba points are in two spatial clusters (Figure 30) that also have high densities of artifacts and ceramic vessel sherds. The Alba points are all on chert, mainly from non-local sources, and range from 18.3-38.9 mm in length, 14.1-18.9 mm in width, 2.1-4.6 $\mathrm{mm}$ in thickness, and 3.8-8.3 $\mathrm{mm}$ stem widths.

The other two identified arrow points include a post-A.D. 1200 Perdiz point made from a yellowish-gray chert (see Figure 29g) and a Steiner point made from a heat-treated quartzite (see Figure 29h). Steiner arrow points are among the earliest arrow point forms made in East Texas, and Shafer and Walters (2010) suggest it is found in ca. A.D. 700-800 contexts in the region. The Perdiz and Steiner points are in the southern part of the South sector (Figure CE330-27), but not within any of the high artifact density or ceramic vessel sherd clusters.

The unidentifiable arrow points from the South sector include tip and blade fragments (see Table 11). The blades are serrated (see Figure 29f), as are many of the Alba points, and it is likely these fragments are part of broken and discarded Alba points. Their distribution in and adjacent to the highdensity sherd clusters (see Figures 13 and 31) further supports this suggestion.

\section{Dart Points}

Three dart points are in the South sector artifact assemblage; they are widely but sparsely distributed in the South sector (Figure 32). The first is a Woodland period Gary point from ST 141, $20-40 \mathrm{~cm}$ bs (Figure 33a). The point is made on a gray novaculite, likely obtained from Red River gravels well to the north of the site. The point is $36.4 \mathrm{~mm}$ in length, $23.0 \mathrm{~mm}$ in width, and $6.7 \mathrm{~mm}$ thick. The stem width is $14.6 \mathrm{~mm}$. The thickness and stem width measurements, as well as its small barbs and V-shaped base, suggest it is a Gary, var. Camden point, manufactured in the latter part of the Woodland period (ca. A.D. 400-700) (Leith 2014; Schambach 1982).

The broken Late Archaic Yarbrough point (see Figure 33b) is made on a local heat-treated quartzite. It is at least $45.0 \mathrm{~mm}$ in length and $24.1 \mathrm{~mm}$ in width. The stem is $15.2 \mathrm{~mm}$ wide, and the blade is $7.6 \mathrm{~mm}$ thick. 


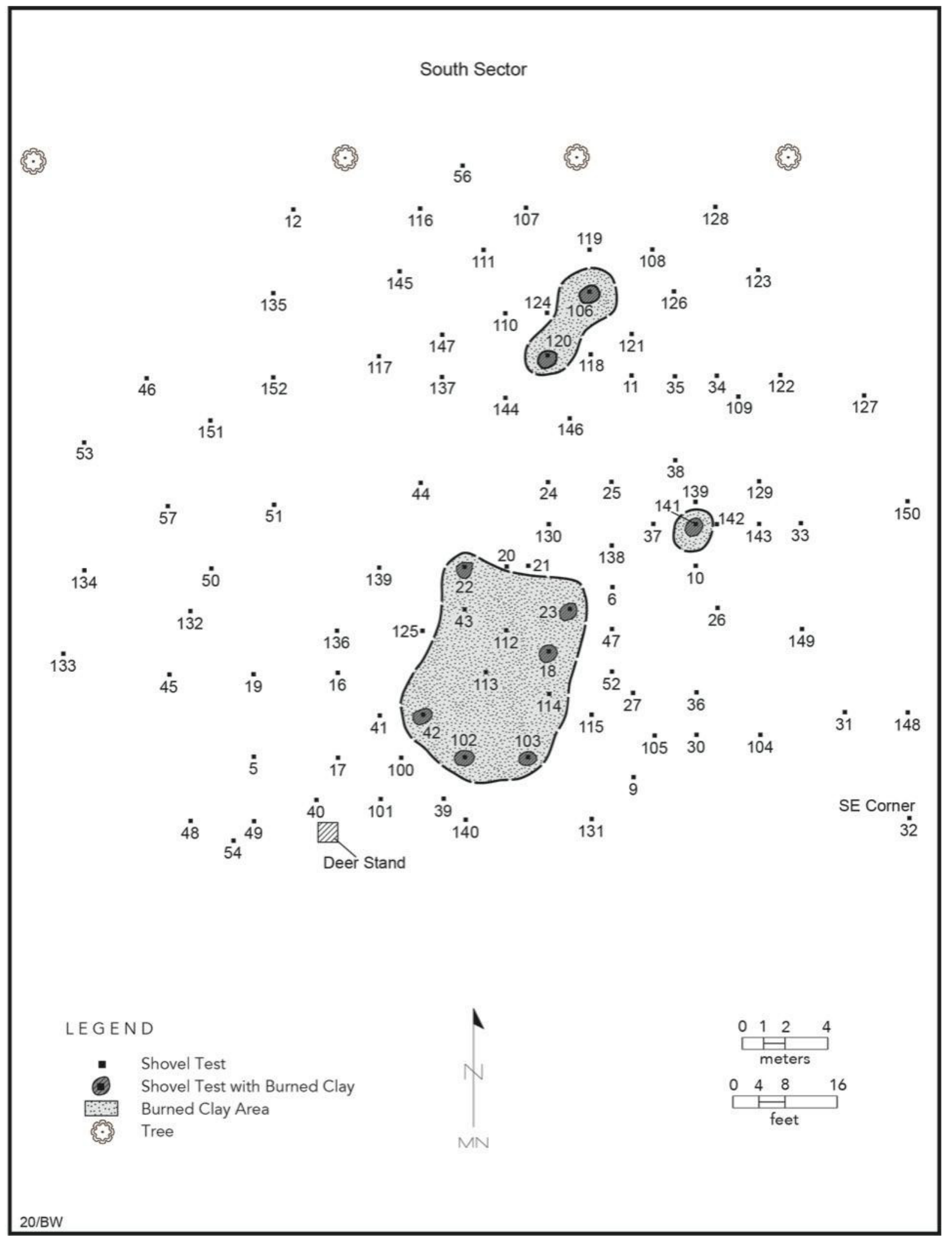

Figure 28. Distribution of shovel tests with burned clay pieces. 
Table 11. Arrow points from South sector shovel tests.

\begin{tabular}{|c|c|c|c|c|c|c|}
\hline ST No. and depth & Type & Raw material & $\mathrm{L}^{*}$ & W & Th & SW \\
\hline ST $21,0-20 \mathrm{~cm}$ & Alba & gray chert & 23.0 & 17.0 & 2.4 & 4.6 \\
\hline ST 23, 0-20 cm & Alba & gray chert & 18.3 & 16.3 & 2.2 & 3.8 \\
\hline ST $33,20-40 \mathrm{~cm}$ & Alba & $\begin{array}{l}\text { reddish- } \\
\text { gray chert }\end{array}$ & 38.9 & 18.9 & 3.1 & 8.3 \\
\hline ST 119, 20-40 & Alba & yellow chert & $36.0+$ & 17.6 & 3.9 & 5.9 \\
\hline ST $121,0-20 \mathrm{~cm}$ & Alba & $\begin{array}{l}\text { very dark } \\
\text { gray chert }\end{array}$ & $17.0+$ & 14.2 & 2.1 & 4.2 \\
\hline ST 144, 0-20 cm & Alba & gray chert & $21.0+$ & $14.3+$ & 3.9 & 7.1 \\
\hline ST $146,40-60 \mathrm{~cm}$ & Alba & light gray chert & $17.0+$ & 14.1 & 4.6 & 5.2 \\
\hline ST $23,20-40 \mathrm{~cm}$ & Alba preform & gray chert & - & 15.8 & 3.4 & - \\
\hline ST $124,0-20 \mathrm{~cm}$ & Alba preform & $\begin{array}{l}\text { grayish-red } \\
\text { chert }\end{array}$ & - & - & - & - \\
\hline ST $113,0-20 \mathrm{~cm}$ & Perdiz & $\begin{array}{l}\text { yellowish-gray } \\
\text { chert }\end{array}$ & 17.9 & 13.0 & 3.3 & 5.6 \\
\hline ST $42,0-20 \mathrm{~cm}$ & Steiner & quartzite & 14.7 & $11.2+$ & 3.3 & 5.6 \\
\hline ST $19,0-20 \mathrm{~cm}$ & $\begin{array}{l}\text { serrated } \\
\text { blade }\end{array}$ & gray chert & - & - & 4.1 & - \\
\hline ST $105,0-20 \mathrm{~cm}$ & fragment & petrified wood & - & - & - & - \\
\hline ST $138,0-20 \mathrm{~cm}$ & $\begin{array}{l}\text { tip; serrated } \\
\text { blade }\end{array}$ & yellow chert & - & 11.0 & 2.6 & - \\
\hline ST $147,20-40 \mathrm{~cm}$ & serrated blade & grayish-yellow chert & - & - & 3.2 & 4.7 \\
\hline ST $147,20-40 \mathrm{~cm}$ & tip & white chert & - & - & - & - \\
\hline
\end{tabular}

$\mathrm{L}=$ length, in $\mathrm{mm}$; $\mathrm{W}=$ width, in $\mathrm{mm}$; Th=thickness, in $\mathrm{mm} ; \mathrm{SW}=$ stem width, in $\mathrm{mm}$

The third dart point is a lanceolate-shaped gray chert point with a serrated blade, a concave base, and an impact fracture (see Figure 33c), possibly evidence of a Late Paleoindian use of the site. There is no basal grinding on the piece. It is at least $28.1 \mathrm{~mm}$ in length, $19.9 \mathrm{~mm}$ in width, and 5.9 $\mathrm{mm}$ in thickness.

\section{Flake Tools}

There are 15 flake tools in the artifact assemblage from the South sector (Table 12). These are found in three different spatial clusters (Figure 34) that are associated with both high artifact density and high sherd density clusters in the sector.

The 15 flake tools include a unifacial scraper of light gray chert, two opposed bilateral useworn flake tools (Figure 35a), and 12 flake tools with unilateral use wear/retouch (Figure 35b). The unbroken tools have use wear lengths that range from 8.8-21.0 mm (see Table 12), and almost all of these tools ( 87 percent) are on flakes of non-local cherts; two unilateral flake tools are on local brown or yellow chert. 


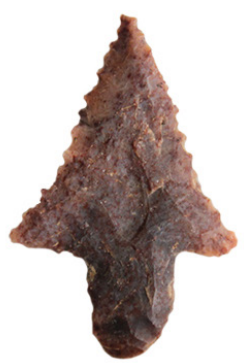

a

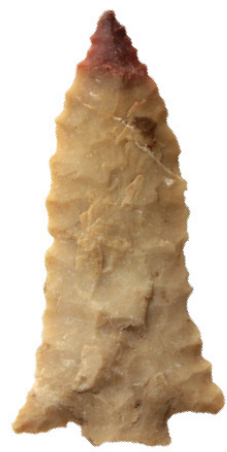

e

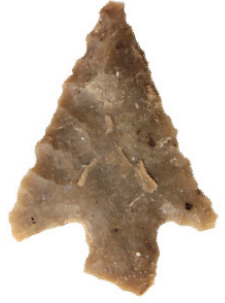

b
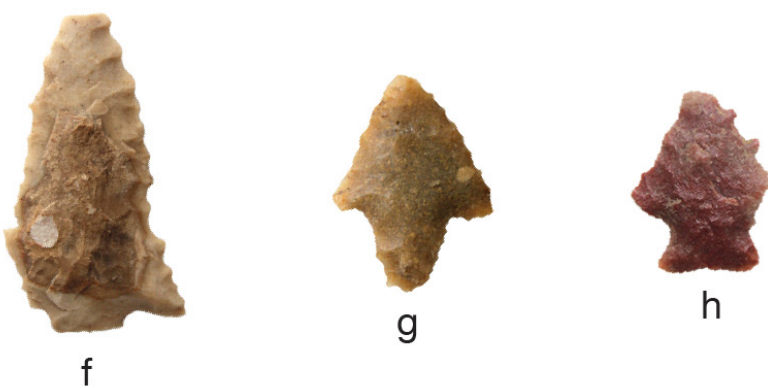

$\mathrm{h}$

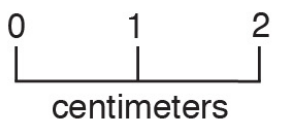

Figure 29. Arrow points from the South sector at the Long site: a, Alba, ST 33, 20-40 cm; b, Alba, ST 21, 0-20 cm bs; c, Alba, ST 144, 0-20 cm; d, Alba, ST 146, 40-60 cm; e, Alba, ST 119, 20-40 cm; f, Arrow point with serrated blade, ST 147, 20-40 cm; g, Perdiz, ST 113, 0-20 cm; h, Steiner arrow point, $S T 42,0-20 \mathrm{~cm}$.

\section{Bifaces}

Early stage bifaces $(n=2$, see Figure $35 \mathrm{c})$, preforms and preform fragments $(n=3)$, a biface fragment $(n=1)$, and a biface tip $(n=1)$ were recovered in the South sector shovel testing (Table 13). They occur in two spatial clusters that overlap with two of the high sherd density clusters (Figure 36; see also Figure 13). Nevertheless, these bifaces are suspected to be associated with pre-A.D. 700 dart point manufacture because of their technological characteristics (i.e., discarded bifaces intended for the manufacture of dart points), not with the later ancestral Caddo components in the South sector.

\section{Cores}

Single ( $n=6)$ and multiple platform $(n=3)$ flake cores are widely distributed in shovel tests in the South sector (Table 14 and Figure 37). There is one cluster in the southern part of the sector that is spatially associated with both high artifact and high sherd density clusters, and a number of the other cores also are found in these clusters. 


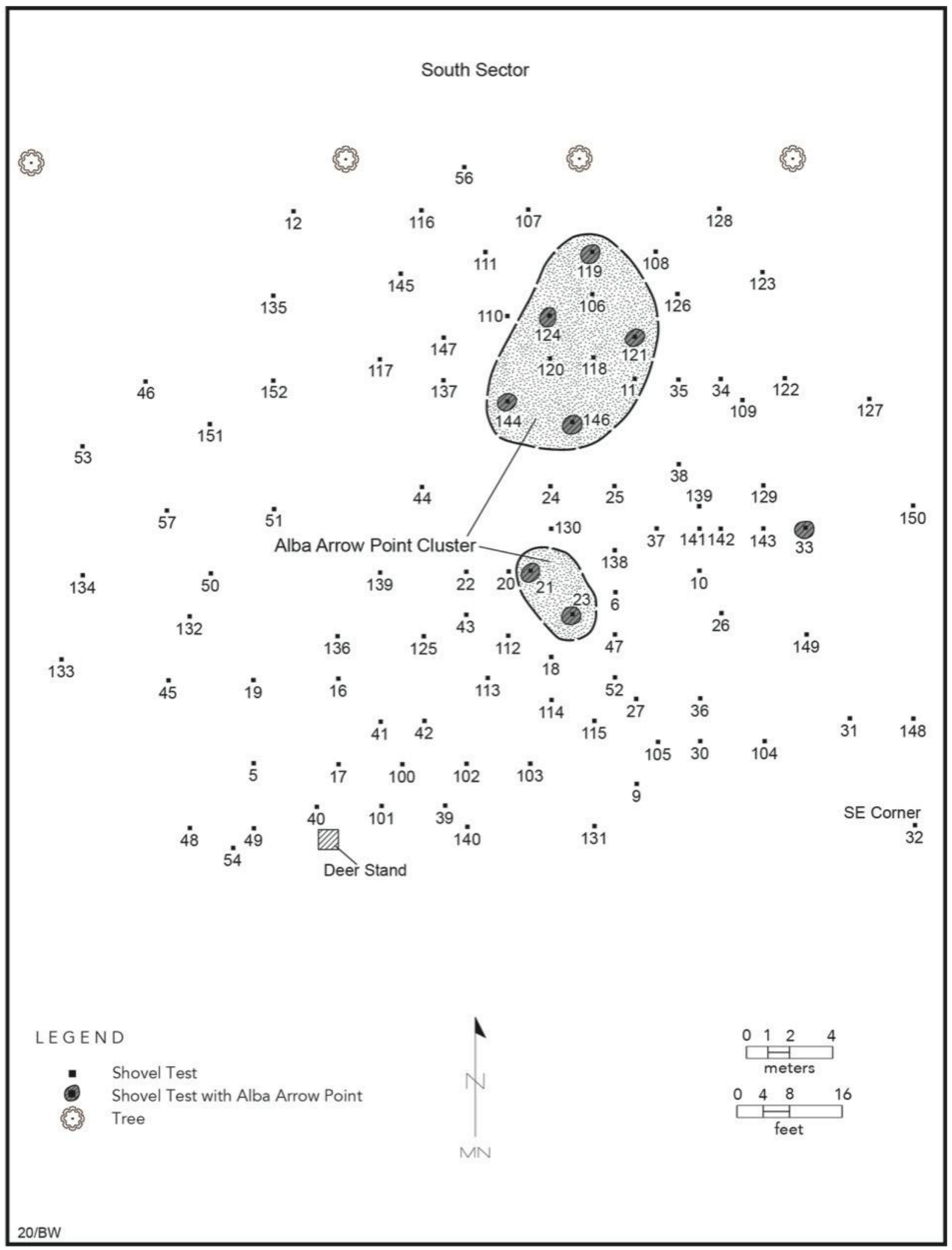

Figure 30. Distribution of shovel tests in the South sector of the Long site with Alba points and Alba preforms. 


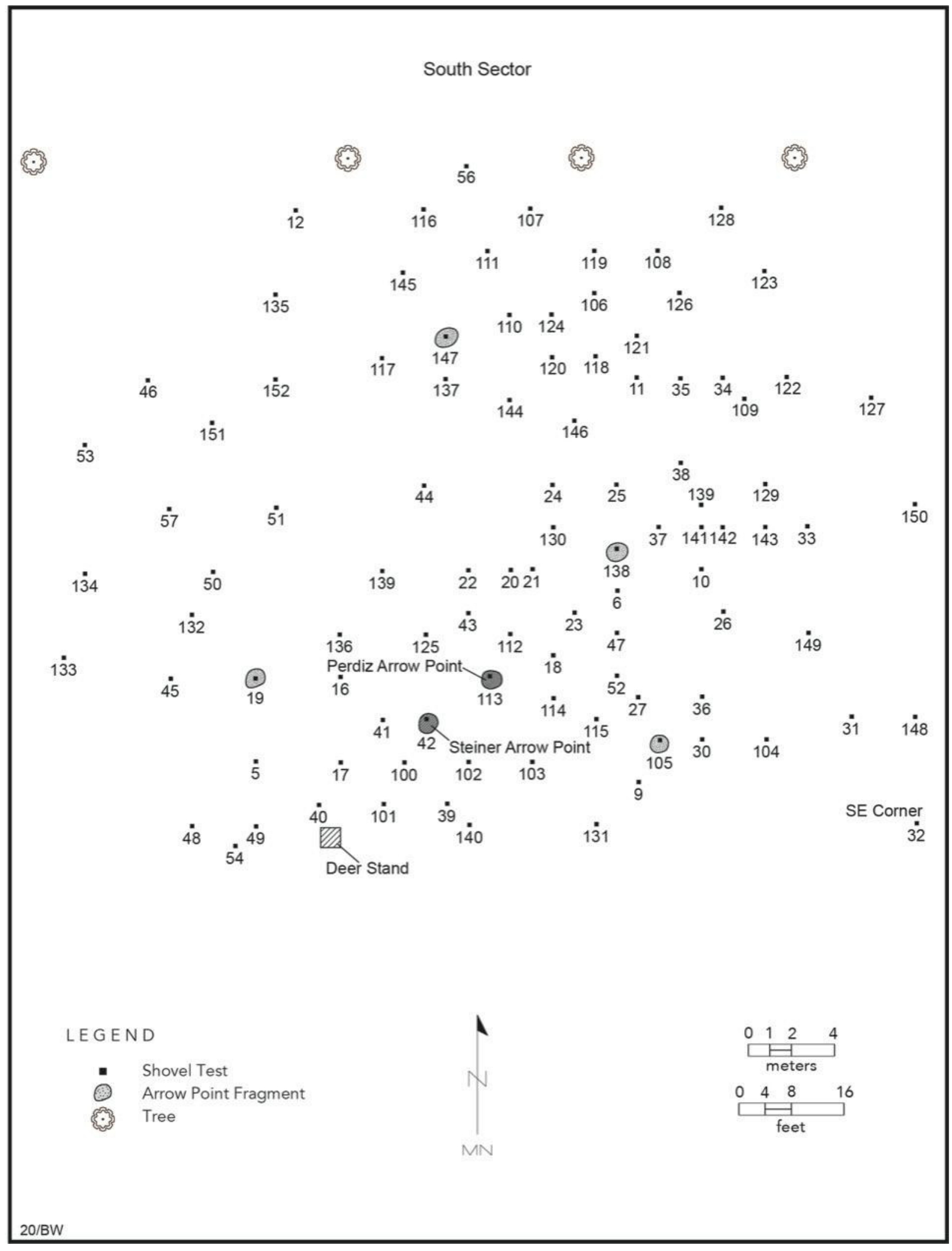

Figure 31. Distribution of Perdiz and Steiner points in the South sector of the Long site, as well as arrow point fragments. 


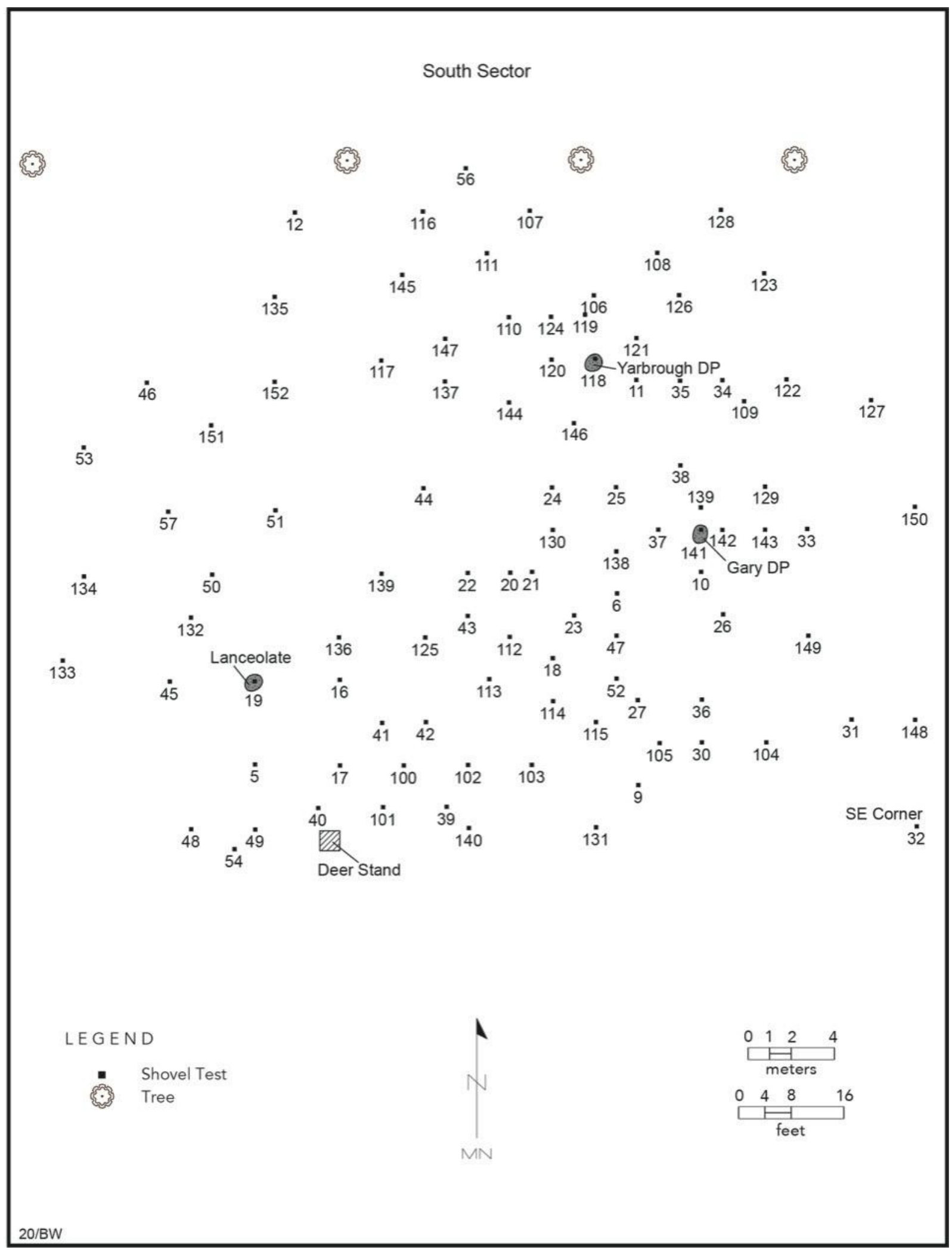

Figure 32. Distribution of dart points in South sector shovel tests at the Long site. 


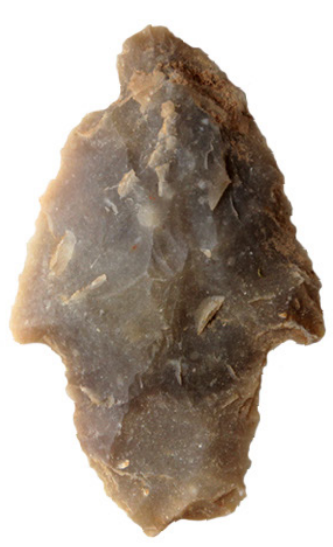

a

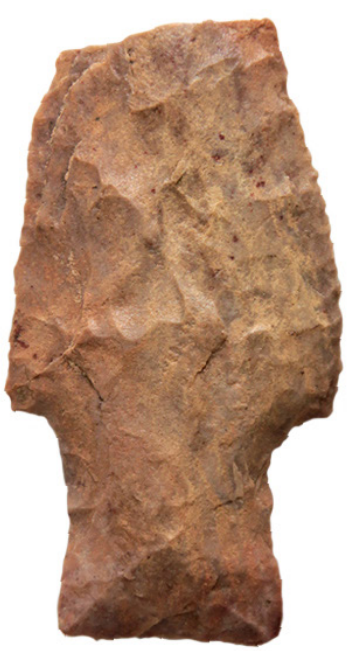

b

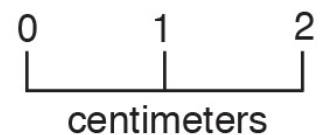

$b$

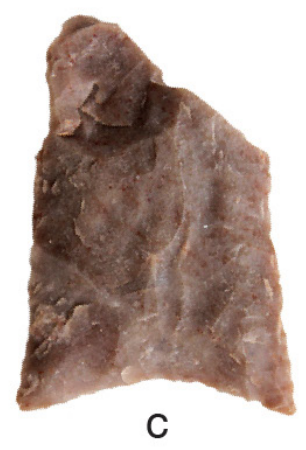

centimeters

Figure 33. Dart points from the South sector of the Long site: a, Gary point, ST 141, 20-40 cm bs; b, Yarbrough point, ST 118, 40-60 cm bs; c, lanceolate point, ST 19, 0-20 cm bs.

Table 12. Flake tools in the South sector.

\begin{tabular}{|c|c|c|c|}
\hline ST No. and depth & Tool type & Use-wear Length & Raw Material \\
\hline ST $3,0-20 \mathrm{~cm}$ & unilateral use-wear & UL: $14.0+\mathrm{mm}$ & light gray chert \\
\hline ST $5,0-20 \mathrm{~cm}$ & unilateral use-wear & UL: $6.9+\mathrm{mm}$ & gray chert \\
\hline ST $5,20-40 \mathrm{~cm}$ & $\begin{array}{l}\text { opposed bilateral } \\
\text { use-wear }\end{array}$ & $\begin{array}{l}\mathrm{UL}: 8.8 \mathrm{~mm}, 16.1 \\
\mathrm{~mm}\end{array}$ & gray chert \\
\hline $\mathrm{ST} 17,20-40 \mathrm{~cm}$ & unilateral use-wear & $\mathrm{UL}: 9.5+\mathrm{mm}$ & brown chert \\
\hline ST $18,20-40 \mathrm{~cm}$ & unilateral use-wear & UL: $20.0+\mathrm{mm}$ & gray chert \\
\hline ST $18,20-40 \mathrm{~cm}$ & unilateral use-wear & UL: $13.5 \mathrm{~mm}$ & light gray chert \\
\hline ST $21,40-60 \mathrm{~cm}$ & $\begin{array}{l}\text { opposed bilateral } \\
\text { use-wear }\end{array}$ & $\begin{array}{l}\text { UL: } 14.2 \mathrm{~mm}, 12.0 \\
\mathrm{~mm}\end{array}$ & gray chert \\
\hline ST $23,0-20 \mathrm{~cm}$ & unilateral use-wear & $\mathrm{UL}: 12.0 \mathrm{~mm}$ & light gray chert \\
\hline ST $112,40-60 \mathrm{~cm}$ & unilateral use-wear & UL: $14.0 \mathrm{~mm}$ & grayish-blue chert \\
\hline ST $125,0-20 \mathrm{~cm}$ & unilateral use-wear & $\mathrm{UL}: 12.9+\mathrm{mm}$ & light gray chert \\
\hline ST $128,0-20 \mathrm{~cm}$ & unilateral use-wear & UL: $17.3+\mathrm{mm}$ & gray chert \\
\hline ST $137,0-20 \mathrm{~cm}$ & unilateral use-wear & UL: $20.9+\mathrm{mm}$ & gray chert \\
\hline ST $138,20-40 \mathrm{~cm}$ & unilateral use wear & UL: $13.8+\mathrm{mm}$ & yellow chert \\
\hline ST $141,0-20 \mathrm{~cm}$ & unilateral use-wear & UL: $13.1+\mathrm{mm}$ & light gray chert \\
\hline ST $144,20-40 \mathrm{~cm}$ & unifacial scraper & UL: $21.0 \mathrm{~mm}$ & light gray chert \\
\hline
\end{tabular}

$\mathrm{UL}=$ use-wear length 


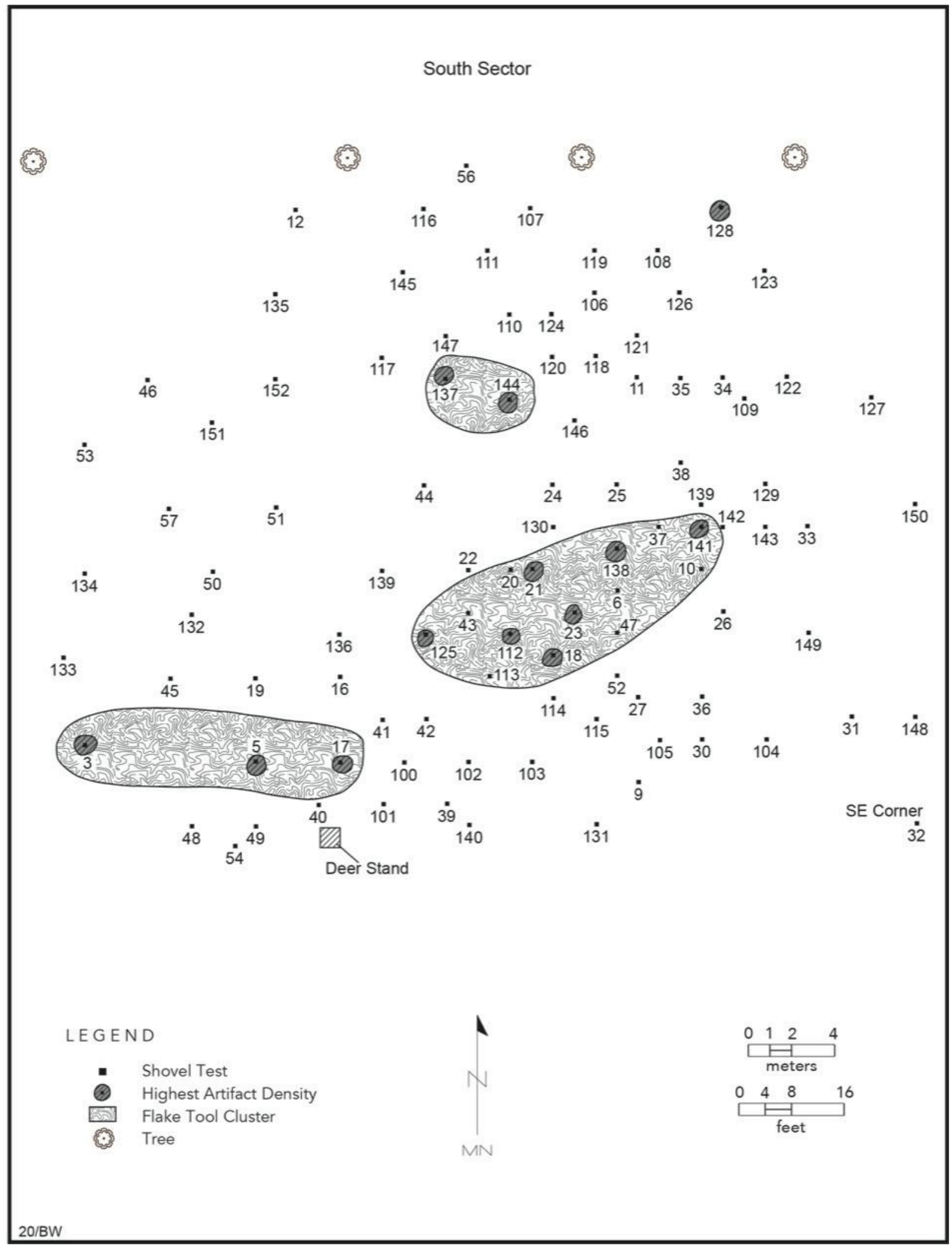

Figure 34. Distribution of flake tools in shovel tests in the South sector. 


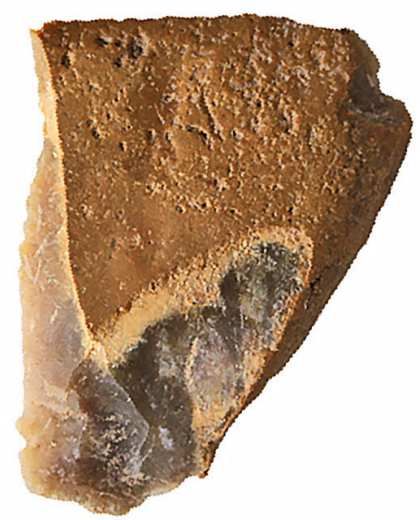

a

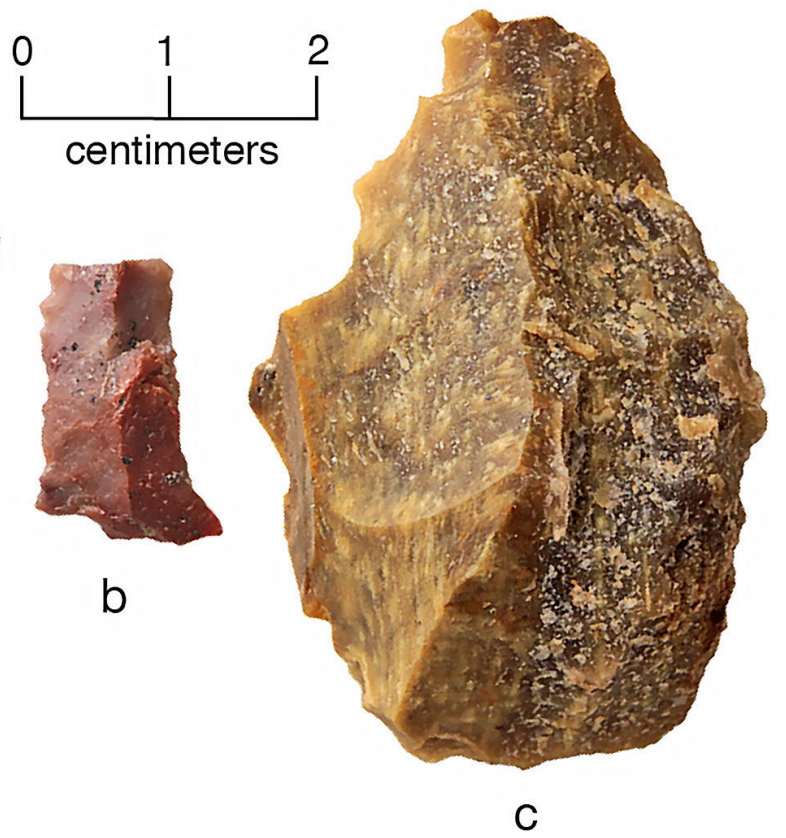

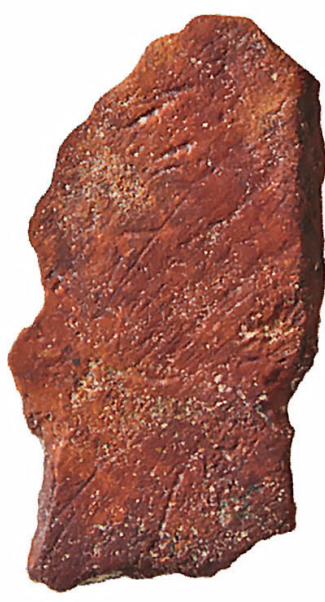

d

Figure 35. Lithic tools and red ochre from the South sector at the Long site: a, opposed bilateral flake tool, ST 5, 20-40 cm; b, unilateral flake tool, ST 137, 0-20 cm; c, early stage biface, ST 129, 20-40 cm; d, a piece of scratched red ochre.

Table 13. Bifaces from the South sector.

\begin{tabular}{|c|c|c|c|c|c|}
\hline ST No. and depth & Biface form & $\mathrm{L}$ & W & Th & Raw material \\
\hline ST $18,20-40 \mathrm{~cm}$ & Early stage & 50.1 & 23.9 & 15.6 & petrified wood \\
\hline ST $23,60-80 \mathrm{~cm}$ & preform & 39.0 & 22.0 & 11.9 & quartzite \\
\hline ST $25,40-60 \mathrm{~cm}$ & biface fragment & - & 26.2 & 10.2 & $\begin{array}{l}\text { coarse-grained } \\
\text { quartzite }\end{array}$ \\
\hline ST $101,20-40 \mathrm{~cm}$ & preform fragment & - & 28.2 & 9.3 & petrified wood \\
\hline ST $109,20-40 \mathrm{~cm}$ & preform fragment & - & 24.1 & 8.4 & petrified wood \\
\hline ST $112,40-60 \mathrm{~cm}$ & tip fragment & - & 23.1 & 6.7 & petrified wood \\
\hline ST $129,20-40 \mathrm{~cm}$ & Early stage & 51.0 & 34.5 & 18.0 & petrified wood \\
\hline
\end{tabular}

Table 14. Cores from South sector shovel tests.

\begin{tabular}{llll}
\hline ST No. and depth & Core type & Cortex & Raw material \\
\hline ST $5,0-20 \mathrm{~cm}$ & single platform & cortical & yellowish-gray chert \\
ST $5,20-40 \mathrm{~cm}$ & single platform & cortical & quartzite \\
ST $6,0-20 \mathrm{~cm}$ & single platform & cortical & petrified wood \\
ST $18,40-56 \mathrm{~cm}$ & multi-platform & cortical & yellowish-gray chert \\
ST $23,20-40 \mathrm{~cm}$ & multi-platform & & brownish-gray chert \\
ST $24,0-20 \mathrm{~cm}$ & single platform & cortical & brown chert \\
ST $57,20-38 \mathrm{~cm}$ & single platform & cortical & petrified wood \\
ST $118,40-60 \mathrm{~cm}$ & single platform & cortical & brownish-dark gray chert \\
ST $129,20-40 \mathrm{~cm}$ & multi-platform & cortical & quartzite \\
\hline
\end{tabular}




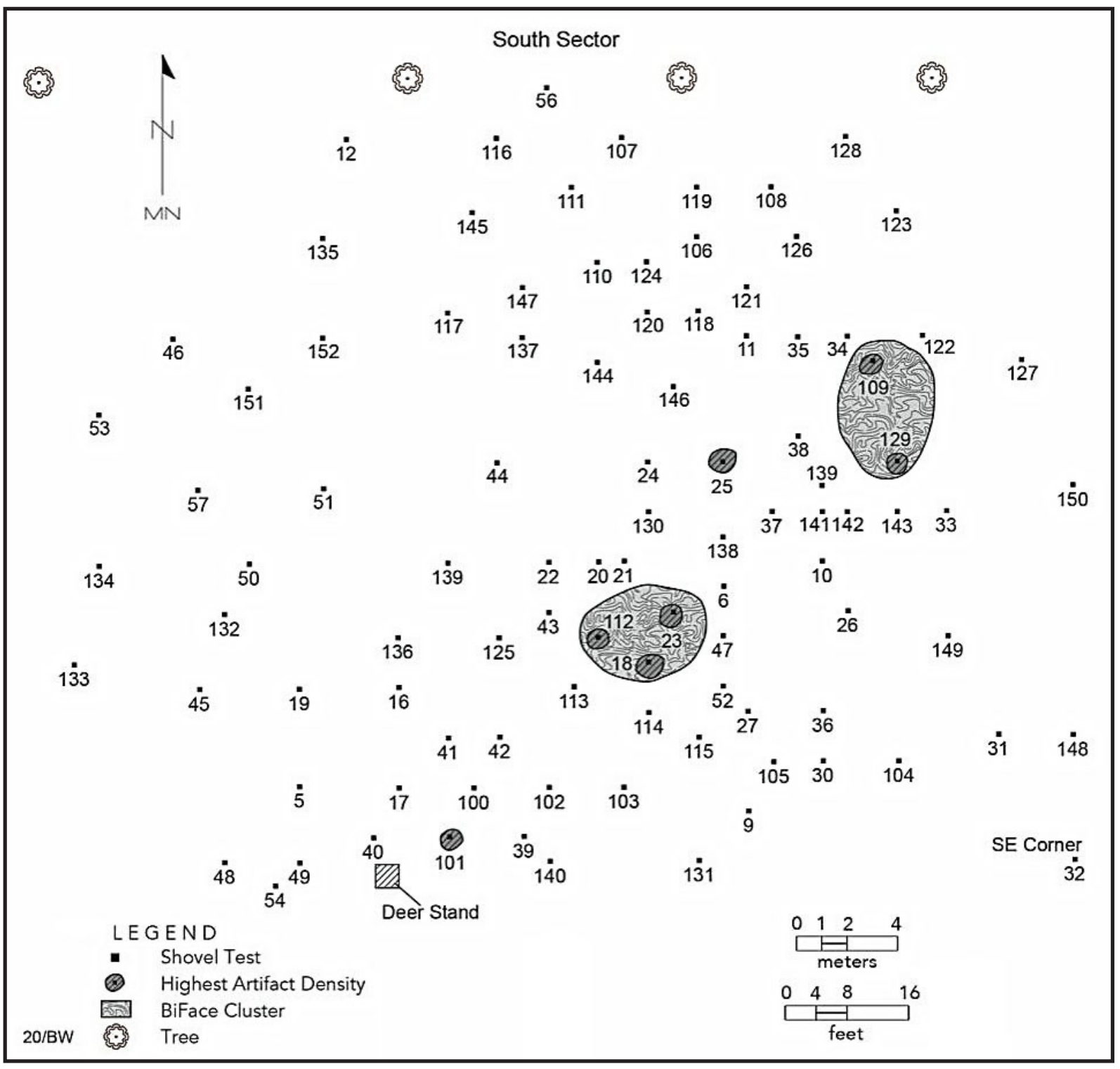

Figure 36. Distribution of bifaces in South sector shovel tests.

The cores have had flakes removed from one or multiple platforms on pebble-sized pieces of raw material with smoothed cortical remnants; these pebbles were likely collected in local stream gravels. Raw materials represented in the cores include quartzite $(n=2)$, petrified wood $(n=2)$, and different colors of chert: yellowish-gray $(n=2)$, brownish-gray $(n=1)$, brown $(n=1)$, and brownishdark gray $(n=1)$; the latter may be from a non-local raw material source.

\section{Lithic Debris}

The 439 pieces of lithic debris recovered in South sector shovel tests occur in two small spatial clusters in the southern part of the sector (Figure 38). These clusters are also associated with two of the three high artifact density clusters (see Figure 11), and three of the high sherd density clusters (see Figure 13). 


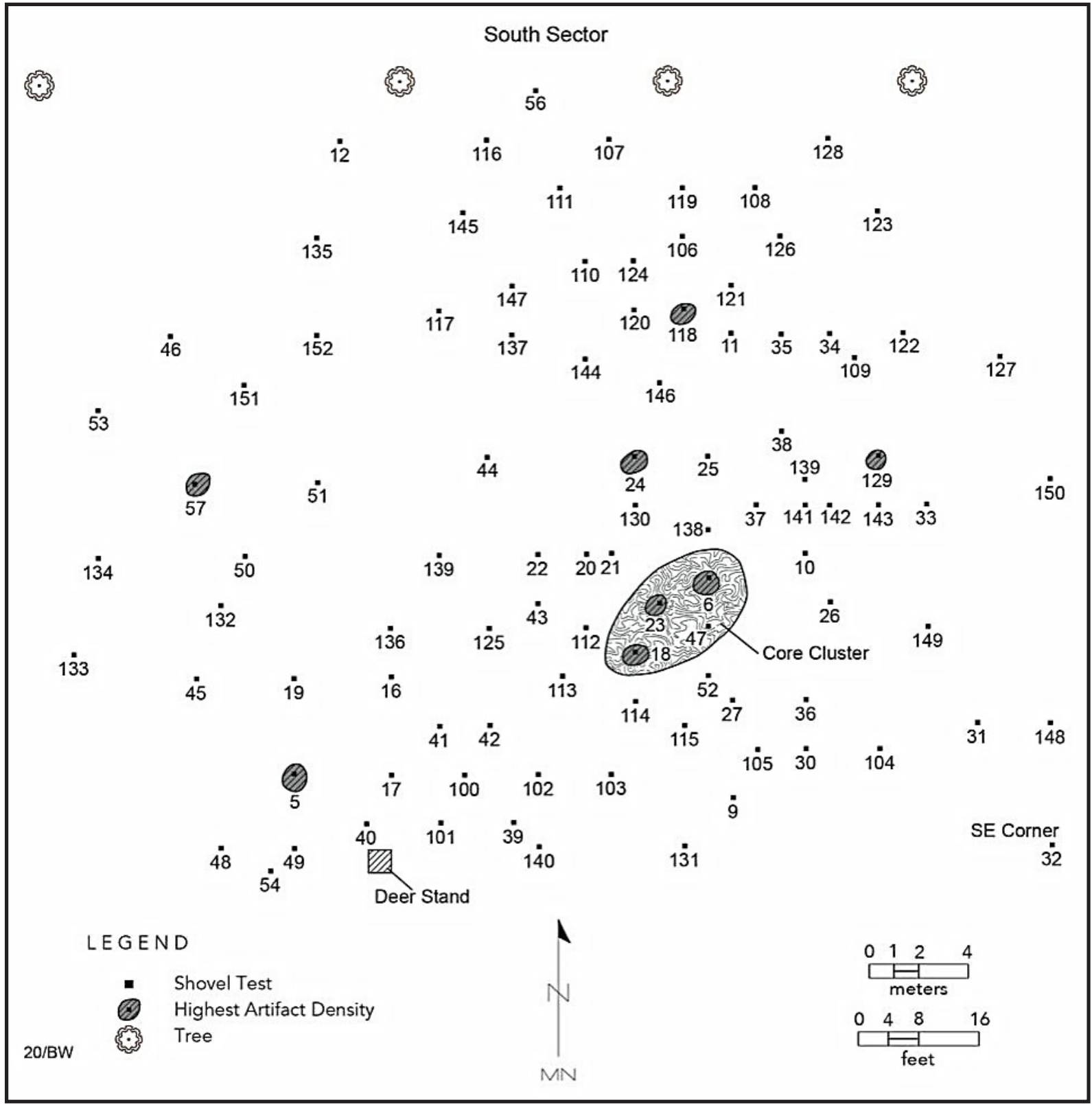

Figure 37. Distribution of cores in South sector shovel tests.

The lithic debris includes pieces on raw materials of local origin, including quartzite (19.1 percent) and petrified wood (9.5 percent) and earth-toned cherts (15.4 percent), a non-local Manning Fused Glass (1.6 percent, see Brown 1976, and numerous pieces of non-local cherts of a wide variety of colors (54.1 percent) (Table 15). The proportion of lithic debris in the South sector on non-local raw materials is significant.

The most common raw materials represented in the South sector lithic debris are gray chert (18.9 percent, and 41.0 percent cortical), quartzite, primarily heat-treated (15.5 percent, and 66.2 percent cortical), petrified wood (9.6 percent, and 42.9 percent cortical), yellowish-gray chert (7.1 percent, and 58.1 percent cortical), and brownish-gray chert (5.7 percent, and 52 percent cortical) (see Table 15). 


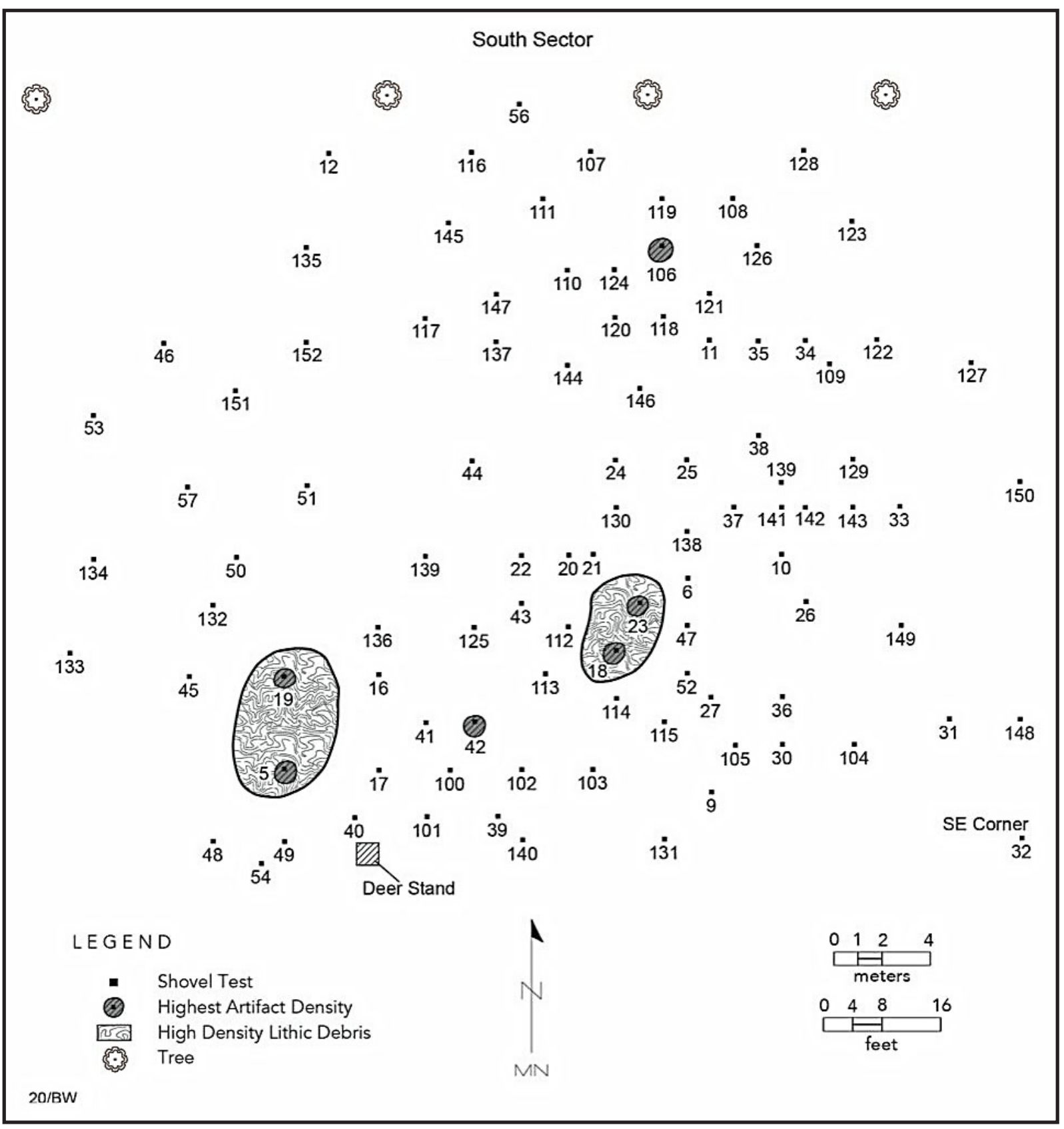

Figure 38. High density lithic debris clusters and individual shovel tests with high lithic debris densities in the South sector.

Almost 50 percent of the lithic debris has cortical remnants, mainly smoothed and streamrolled, suggesting that the raw materials were gathered from stream gravels, whether the material was of local or non-local in origin (see Table 15). The highest proportion of cortical pieces are in the quartzite (66.2 percent), local cherts (61.8 percent), non-local chert (45.8 percent), and petrified wood (42.9 percent). Conversely, none of the distinctive coarse quartzite pieces have cortical remnants, and only 28.6 percent of the Manning Fused Glass have cortical remnants. The frequency of Manning Fused Glass in the South sector (1.6 percent) is quite comparable to its frequency in the Early Caddo period component at the George C. Davis site: 2.28 percent (Brown 1976:196). Brown 
Table 15. Lithic debris from the South sector.

\begin{tabular}{|c|c|c|c|}
\hline Raw Material & Non-cortical & Cortical & $\mathrm{N}$ \\
\hline Manning Fused Glass* & 5 & 2 & 7 \\
\hline yellow chert & 12 & 5 & 17 \\
\hline yellowish-brown chert & 3 & 2 & 5 \\
\hline brown chert & 3 & 14 & 17 \\
\hline brownish-red chert & 1 & 1 & 2 \\
\hline dark brown chert & 1 & - & 1 \\
\hline brownish-yellow chert & 1 & 3 & 4 \\
\hline red chert & 2 & 12 & 14 \\
\hline reddish-brown chert & 3 & 2 & 5 \\
\hline reddish-dark brown chert & - & 1 & 1 \\
\hline reddish-yellow chert & - & 2 & 2 \\
\hline bluish-gray chert* & 2 & - & 2 \\
\hline brownish-gray chert* & 12 & 13 & 25 \\
\hline yellowish-gray chert* & 13 & 18 & 31 \\
\hline reddish-gray chert* & 3 & 3 & 6 \\
\hline reddish-white chert* & 1 & 1 & 2 \\
\hline grayish-black chert* & 1 & - & 1 \\
\hline grayish-blue chert* & 3 & 4 & 7 \\
\hline grayish-brown chert* & 4 & 11 & 15 \\
\hline grayish-red chert* & 1 & 1 & 2 \\
\hline grayish-yellow chert* & 1 & 2 & 3 \\
\hline grayish-white chert* & - & 3 & 3 \\
\hline whitish-gray chert* & - & 1 & 1 \\
\hline gray chert* & 49 & 34 & 83 \\
\hline dark gray chert* & 11 & 6 & 17 \\
\hline very dark gray chert* & 4 & 1 & 5 \\
\hline very dark gray-blue chert* & 1 & 1 & 2 \\
\hline light gray chert* & 19 & 9 & 28 \\
\hline white chert* & 4 & 1 & 5 \\
\hline Quartzite & 23 & 45 & 68 \\
\hline Coarse Quartzite & 16 & - & 16 \\
\hline Petrified Wood & 24 & 18 & 42 \\
\hline Totals & 223 & 216 & 439 \\
\hline
\end{tabular}

*non-local in origin 
(1976:196) notes "that this material appears to have been used as a minor lithic resource throughout the Caddoan [sic] occupation of the site, and seems to occur in all parts of the site except the Special Mortuary, Mound C."

There are a wide variety of lithic raw materials represented in the North sector lithic debris, including Manning fused glass (3.3 percent) (see Brown 1976), various cherts, both local and non-local in origin (56.7 percent), two kinds of quartzite (30.0 percent), and petrified wood (10.0 percent) (Table 16). Only the local chert, quartzite, and petrified lithic debris include smoothed and stream-rolled cortical pieces, likely obtained as pebbles and small cobbles in stream gravels. The non-local cherts and Manning fused glass are represented only by non-cortical pieces. The non-local lithic raw materials in the lithic debris comprise 4.3 percent of the small North sector

Table 16. Lithic debris from the North sector.

\begin{tabular}{|c|c|c|c|}
\hline Raw Material & Non-cortical & Cortical & $\mathrm{N}$ \\
\hline Manning fused glass* & 1 & - & 1 \\
\hline brownish-red chert & 1 & - & 1 \\
\hline gray chert* & 4 & - & 4 \\
\hline light gray chert* & 7 & - & 7 \\
\hline light grayish-red chert & $*$ & 1 & - \\
\hline \multicolumn{4}{|l|}{1} \\
\hline red chert & - & 1 & 1 \\
\hline reddish-gray chert* & 1 & - & 1 \\
\hline yellowish-gray chert & 1 & 1 & 2 \\
\hline Quartzite, heat-treated & 1 & 3 & 4 \\
\hline Quartzite, non-heat-treated & 1 & 1 & 2 \\
\hline Coarse Quartzite & 3 & - & 3 \\
\hline Petrified wood & - & 3 & 3 \\
\hline Totals & 21 & 9 & 30 \\
\hline
\end{tabular}

*non-local in origin

assemblage. The lithic debris is concentrated primarily in the northern part of the North sector, with the exception of ST 158 in the southwestern part of the sector (Figure 39).

One of the light gray chert flakes is a small blade (Figure 40). The blade has no cortex.

\section{Ground Stone Tools}

Ten ferruginous sandstone ground stone tools were recovered in shovel tests in the South sector (Table 17). Most of them are in one spatial cluster in the southeastern part of the sector (Figure 41) that overlaps with one high artifact density cluster and parts of two high sherd density clusters (see 


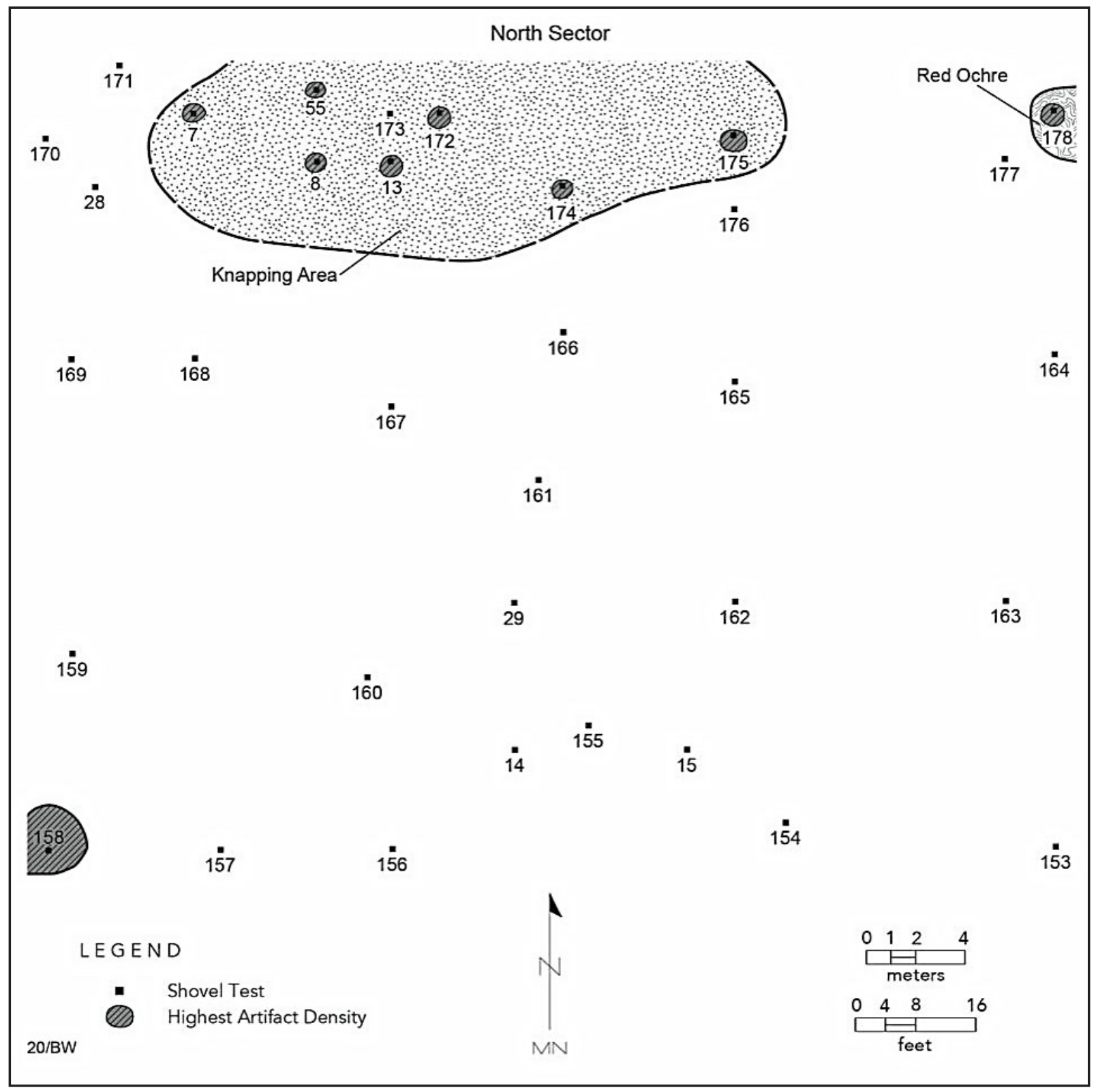

Figure 39. Distribution of shovel tests with lithic debris in the North sector of the Long site.

Figure 40. Blade from ST 174, $40-60 \mathrm{~cm}$ bs, in the North sector of the Long site.
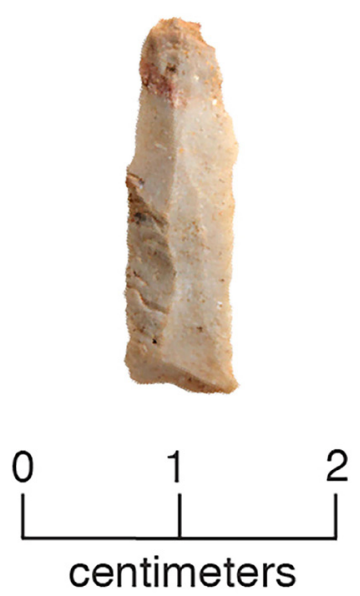
Figures 11 and 13). The distribution of the ground stone tools suggests that the ancestral Caddo occupants of the site were still processing, pounding, and grinding plant foods with stone tools, and had not changed to the use of wood pestles and mortars. Ground stone tools in the South sector include pitted stones $(n=2)$, manos $(n=3)$, manos/pitted stones $(n=2)$, and grinding slab fragments $(n=3)$.

Table 17. Ground stone tools in the South sector.

\begin{tabular}{lll} 
ST No. and depth & Tool type & Raw material \\
\hline ST $10,0-20 \mathrm{~cm}$ & pitted stone & ferruginous sandstone \\
ST $23,20-40 \mathrm{~cm}$ & mano fragment & ferruginous sandstone \\
ST $26,10 \mathrm{~cm}$ & bi-pitted stone & ferruginous sandstone \\
ST $54,20-40 \mathrm{~cm}$ & mano & ferruginous sandstone \\
ST $57,20-40 \mathrm{~cm}$ & grinding slab fragment & ferruginous sandstone \\
ST $108,20-37 \mathrm{~cm}$ & 2 grinding slab fragments & ferruginous sandstone \\
ST $109,0-20 \mathrm{~cm}$ & mano-pitted stone & ferruginous sandstone \\
ST $138,20-40 \mathrm{~cm}$ & mano-pitted stone & ferruginous sandstone \\
ST $141,20-40 \mathrm{~cm}$ & mano* & ferruginous sandstone
\end{tabular}

*also fire-cracked

The unbroken mano in ST 54 in the southern part of the South sector is 87 × 59 x $27 \mathrm{~mm}$ in length, width, and thickness. The mano-pitted stone from ST 138 in the ground stone tool cluster (see Figure 41) is $93.2 \mathrm{~mm}$ in length, $82.1 \mathrm{~mm}$ in width, ad $27.9 \mathrm{~mm}$ in thickness. The pit itself is $16 \mathrm{~mm}$ in diameter. The one-sided pitted stone in ST 10 is $103 \times 65 \times 43 \mathrm{~mm}$ in length, width, and thickness, and has a 17-mm diameter pit.

\section{Modified Red Ochre}

Six pieces of modified red ochre pebbles are in the Long site artifact assemblage (Table 18). These pieces have been smoothed, scratched (see Figure 35d), or polished, during efforts to remove pieces of the red ochre to be made into a powder to be used in the manufacture of red clay pigments or paints for tattoos. The modified red ochre pieces are widely distributed in the South sector, but 50 percent are spatially associated with either high artifact density clusters or high sherd density clusters (Figure 42).

There is a single piece of modified and smoothed red ochre, a source of red pigment, in one of the shovel tests in the North sector (ST 178, 0-20 cm bs).

\section{Fire-Cracked Rock}

Evidence of occasional hot rock cooking, earth ovens, or rock hearth use (see Black and Thoms 2014) in the South sector is marked by the recovery of 15 pieces of ferruginous sandstone firecracked rocks (Table 19). Although there are two small fire-cracked rock clusters in the sector (Figure 43), the rocks are widely scattered in individual shovel tests in both the north and southern parts of the sector. Both of the fire-cracked rock clusters are spatially associated with two of the high-density artifact clusters (see Figure 11) and two of the high density sherd clusters (see Figure 13). 


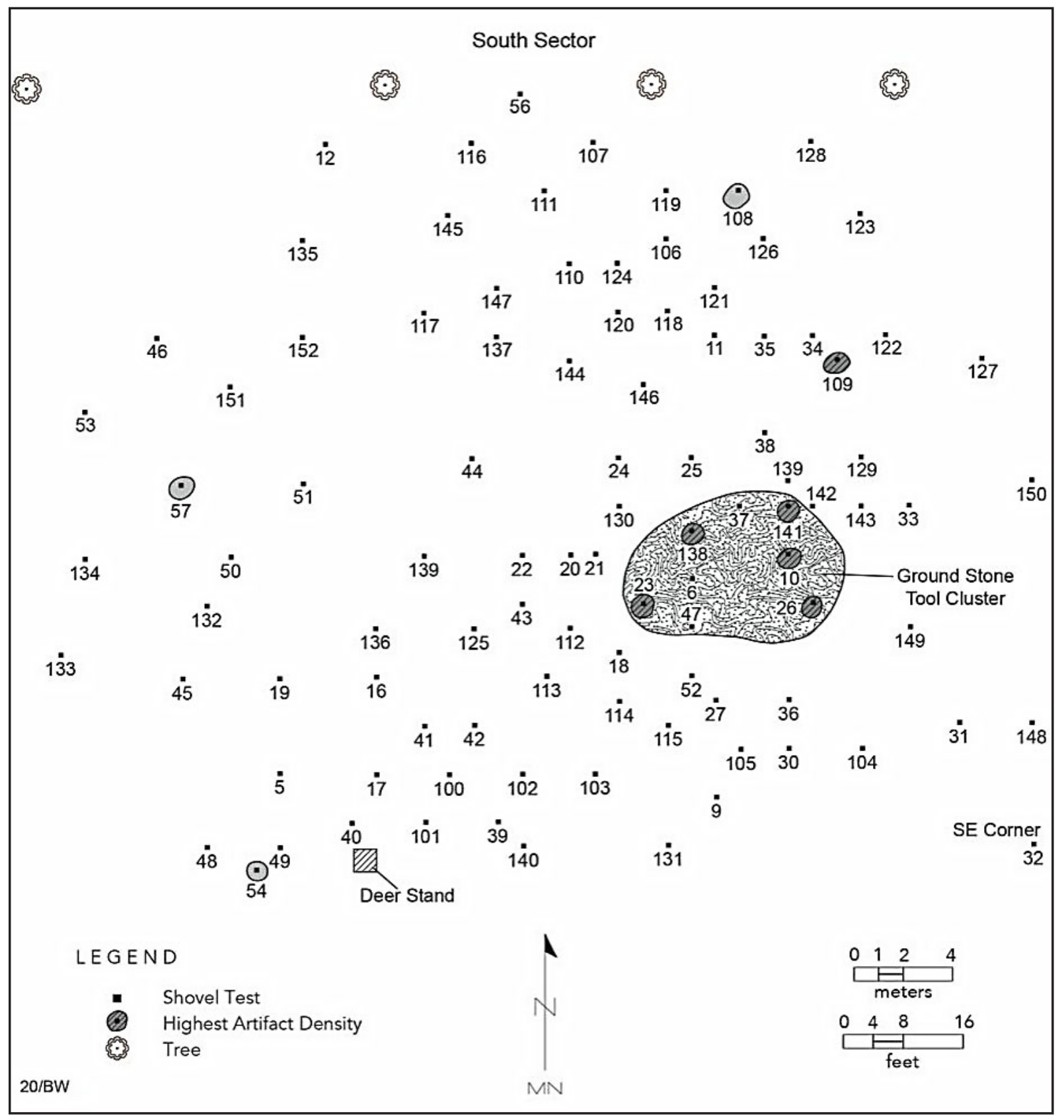

Figure 41. Distribution of ground stone tools in shovel tests in the South sector.

Table 18. Modified red ochre pieces in South sector shovel tests.

ST No. and depth

ST $4,0-20 \mathrm{~cm}$

ST $51,20-40 \mathrm{~cm}$

ST $56,20-40 \mathrm{~cm}$

ST $114,20-40 \mathrm{~cm}$

ST $147,20-40 \mathrm{~cm}$
Red ochre pieces

1 piece of polished red ochre

1 piece of scratched red ochre

1 piece of scratched red ochre

1 piece of scratched/smoothed red ochre

2 pieces of scratched red ochre 
Table 19. Fire-cracked rocks in the South sector.

ST No. and depth

ST 3, 0-20 cm

ST 6, 40-60 cm

ST $10,0-20 \mathrm{~cm}$

ST $11,20-40 \mathrm{~cm}$

ST $16,0-20 \mathrm{~cm}$

ST $44,20-40 \mathrm{~cm}$

ST 54, 20-40 cm

ST $110,0-20 \mathrm{~cm}$

ST $118,0-20 \mathrm{~cm}$

ST $118,40-60 \mathrm{~cm}$

ST $135,0-20 \mathrm{~cm}$
Fire-cracked rocks

1 fire-cracked rock

1 fire-cracked rock

1 fire-cracked rock

2 fire-cracked rocks

3 fire-cracked rocks

1 fire-cracked rock

2 fire-cracked rocks

1 fire-cracked rock

1 fire-cracked rock

1 fire-cracked rock

1 fire-cracked rock
Raw material

ferruginous sandstone

ferruginous sandstone

ferruginous sandstone

ferruginous sandstone

ferruginous sandstone

ferruginous sandstone

ferruginous sandstone

ferruginous sandstone

ferruginous sandstone

ferruginous sandstone

ferruginous sandstone

\section{Wood Charcoal}

Only 12 pieces of wood charcoal were recovered in the South sector shovel tests (Table 20). The wood charcoal mainly occurs in two spatial clusters (Figure 44) in the northern and southern parts of the sector. These clusters are associated with two of the high artifact density clusters and two of the high sherd density clusters in the South sector (see Figures 11 and 13).

Only four pieces of wood charcoal were recovered in the North sector (see Table 3).

\section{Charred Nutshells}

Seven shovel tests in the South sector have 13 pieces of charred Hickory (Carya sp.) nutshells (Table 21). Although widely distributed across the sector, there is one spatial cluster of charred nutshells in the southern part (Figure 45). This cluster of nutshell pieces is associated with both high artifact density and ceramic vessel sherd clusters in this part of the site. The seemingly isolated shovel tests with nutshells are also associated with other high artifact and sherd density clusters (see Figures 11 and 13). Radiocarbon dating (see below) has shown that the majority of the recovered charred nutshells, whether in high artifact density or ceramic vessel sherd clusters, are associated with the Middle Caddo period use of the South sector and not with the Early Caddo period Alto phase occupation.

\section{Burned Animal Bones}

Only a few pieces $(n=9)$ of burned animal bone (not further identified to genera or species) were recovered in the South sector shovel tests (Table 22). They are rather equally distributed between 0-60 cm bs in the archaeological deposits, and are spatially distributed in a ca. 80 square meter area that overlaps with two high artifact density clusters (Figure 46; see Figure 11) and two high sherd density clusters (see Figure 13); most of the burned animal bone falls in the southern part of the South sector. 


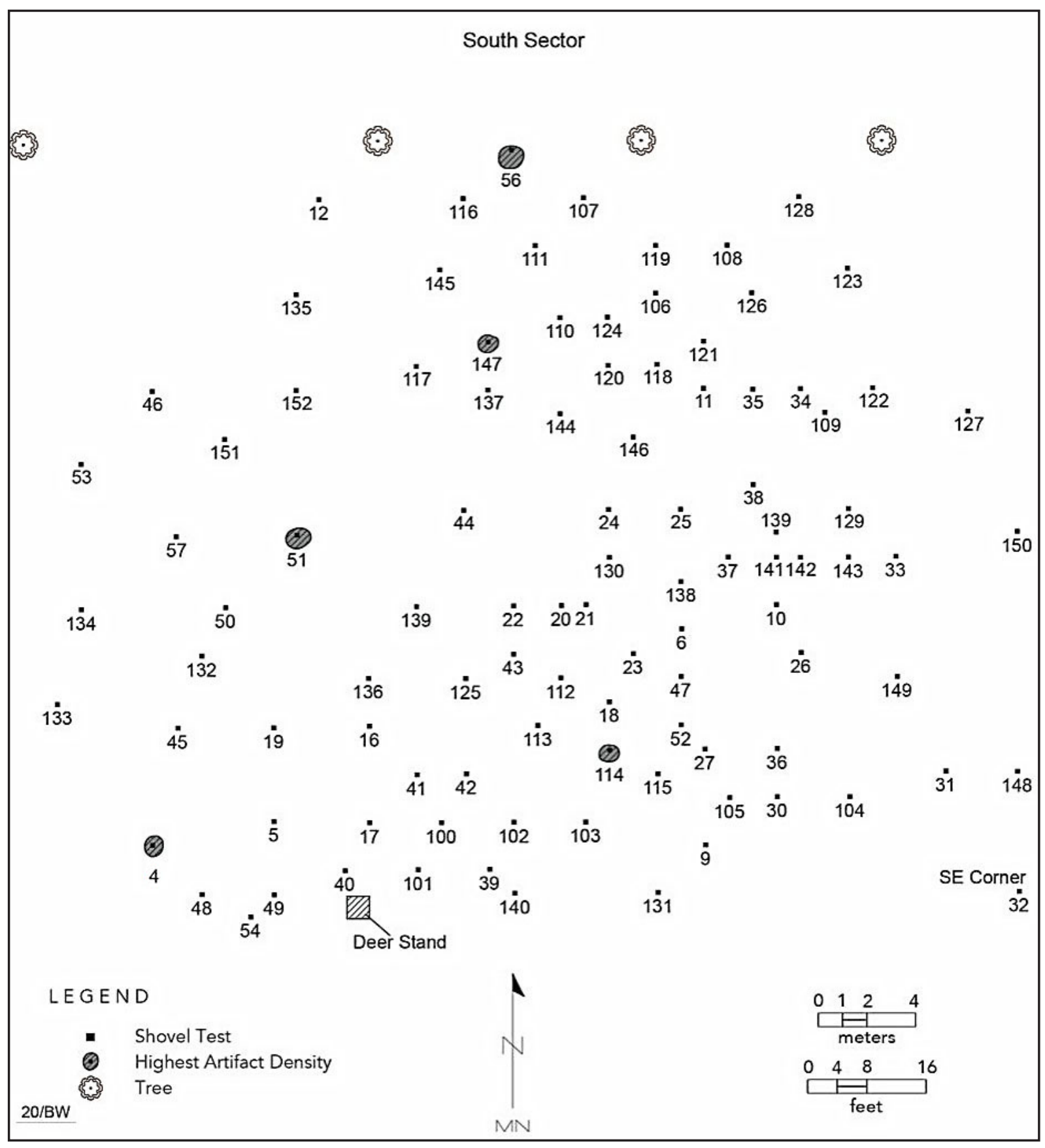

Figure 42. Distribution of modified red ochre pieces in South sector shovel tests.

\section{Radiocarbon Dates from the Long site}

Four samples of charred Hickory (Carya sp.) nutshells from the South sector were submitted to DirectAMS (Bothell, Washington) for radiocarbon dating (see Table 21). The charred nutshells are from four different shovel tests, and they were recovered from depths ranging from $20-37 \mathrm{~cm}$ bs $(\mathrm{n}=1), 20-40 \mathrm{~cm}$ bs $(\mathrm{n}=2)$, and $40-60 \mathrm{~cm}$ bs $(\mathrm{n}=1)$. These samples were thought to be from the same and principal Early Caddo period archaeological deposits (see Table 2) in the South sector, estimated to date at its broadest range to between ca. A.D. 900-1200, but the results indicate in every case that 


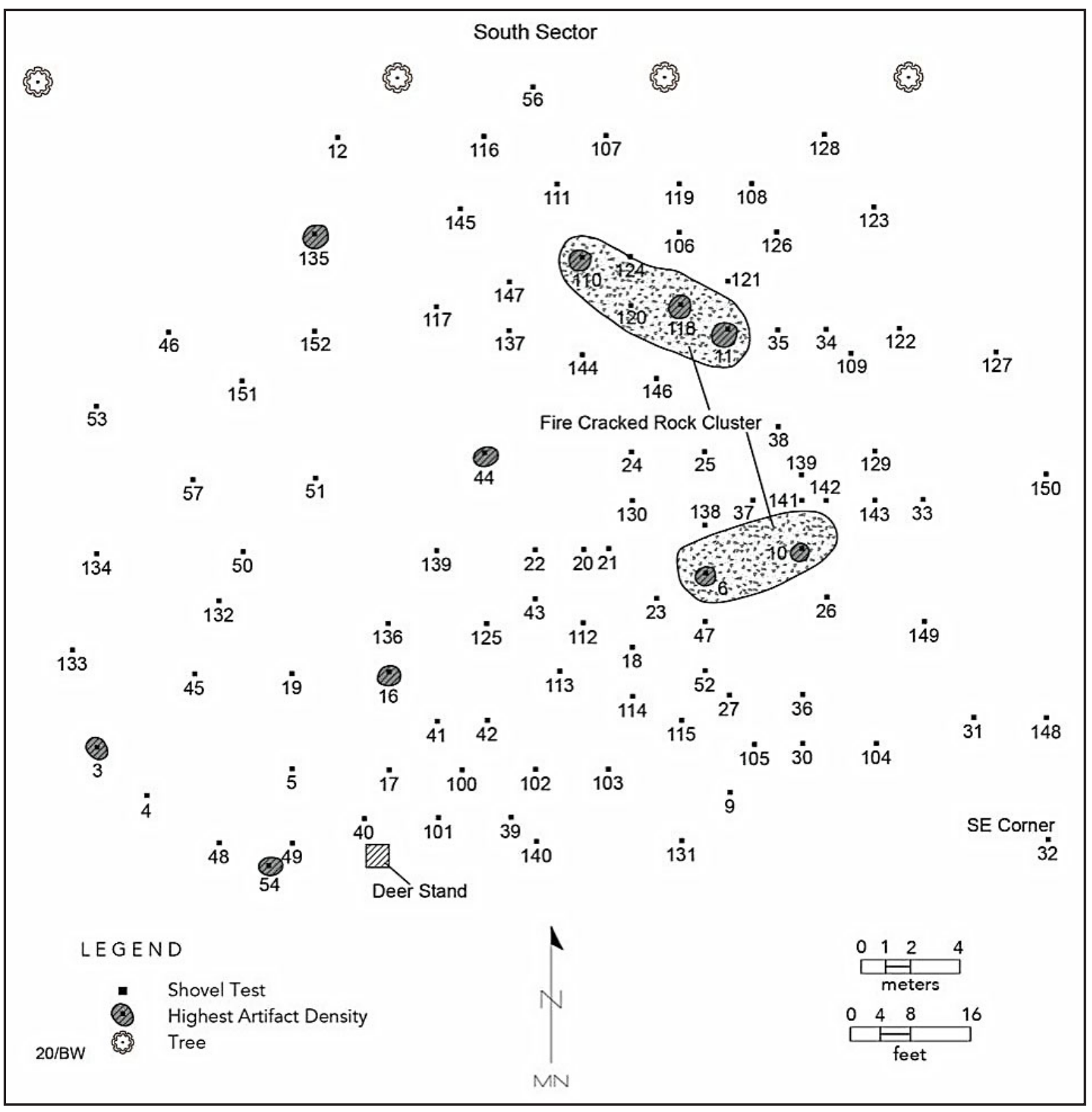

Figure 43. Distribution of fire-cracked rock in shovel tests in the South sector.

the charred nutshells submitted for dating had actually been deposited during the Middle Caddo period use of the Long site.

The results of the radiocarbon analyses are provided in Table 23. The conventional ages range from $569 \pm 28$ B.P. to $736 \pm 29$ B.P., and the mean conventional ages of the four dates range from 739-541 B.P., or A.D. 1211-1409, solidly falling in the Middle Caddo period. The radiocarbon dates were calibrated at 1 sigma (68.3 percent probability) and 2 sigma ( 95.4 percent probability) using INTCal 13 and Calib 7.1 (Reimer et al. 2013; Stuiver et al. 2020).

When calibrated to 2 sigma, the median probability of the four dates ranges from A.D. 12711353 (see Table 23), with a mean probability of A.D. 1313. Also at 2 sigma, the likeliest age range 
Table 20. Wood charcoal in the South sector shovel tests.

ST No. and depth

Wood charcoal pieces

ST $18,20-40 \mathrm{~cm}$

ST $21,40-60 \mathrm{~cm}$

1 piece of wood charcoal

ST $23,0-20 \mathrm{~cm}$

1 piece of wood charcoal

ST $26,0-20 \mathrm{~cm}$

1 piece of wood charcoal

ST $57,0-20 \mathrm{~cm}$

1 piece of wood charcoal

ST $57,20-38 \mathrm{~cm}$

1 piece of wood charcoal

ST $106,20-40 \mathrm{~cm}$

1 piece of wood charcoal

ST $108,0-20 \mathrm{~cm}$

1 piece of wood charcoal

ST $121,40-60 \mathrm{~cm}$

1 piece of wood charcoal

ST $138,0-20 \mathrm{~cm}$

1 piece of wood charcoal

ST $147,20-40 \mathrm{~cm}$

2 pieces of wood charcoal

1 piece of wood charcoal

Table 21. Charred nutshells in South sector shovel tests.

ST No. and depth

Nutshell

ST $23,40-60 \mathrm{~cm}$

ST $27,20-40 \mathrm{~cm}$

ST $108,20-37 \mathrm{~cm}$

ST $112,0-20 \mathrm{~cm}$

ST $114,0-20 \mathrm{~cm}$

ST $143,20-40 \mathrm{~cm}$

ST $146,20-40 \mathrm{~cm}$
4 nutshell pieces* (CE330-4 C14 sample)

4 nutshell pieces* (CE330-1 C14 sample)

1 nutshell piece* (CE330-2 C14 sample)

1 nutshell piece

1 nutshell piece

1 nutshell piece* (CE330-3 C14 sample)

1 nutshell piece

*samples submitted for radiocarbon dating, see below

Table 22. Burned animal bones in South sector shovel tests.

ST No. and depth

ST $23,40-60 \mathrm{~cm}$

ST $114,40-54 \mathrm{~cm}$

ST $115,0-20 \mathrm{~cm}$

ST $130,20-40 \mathrm{~cm}$

ST $138,0-20 \mathrm{~cm}$

ST $144,0-20 \mathrm{~cm}$

ST $146,20-40 \mathrm{~cm}$
Animal bones

1 burned animal bone

3 pieces of burned animal bone

1 burned animal bone

1 burned animal bone

1 burned animal bone

1 burned animal bone

1 burned animal bone 


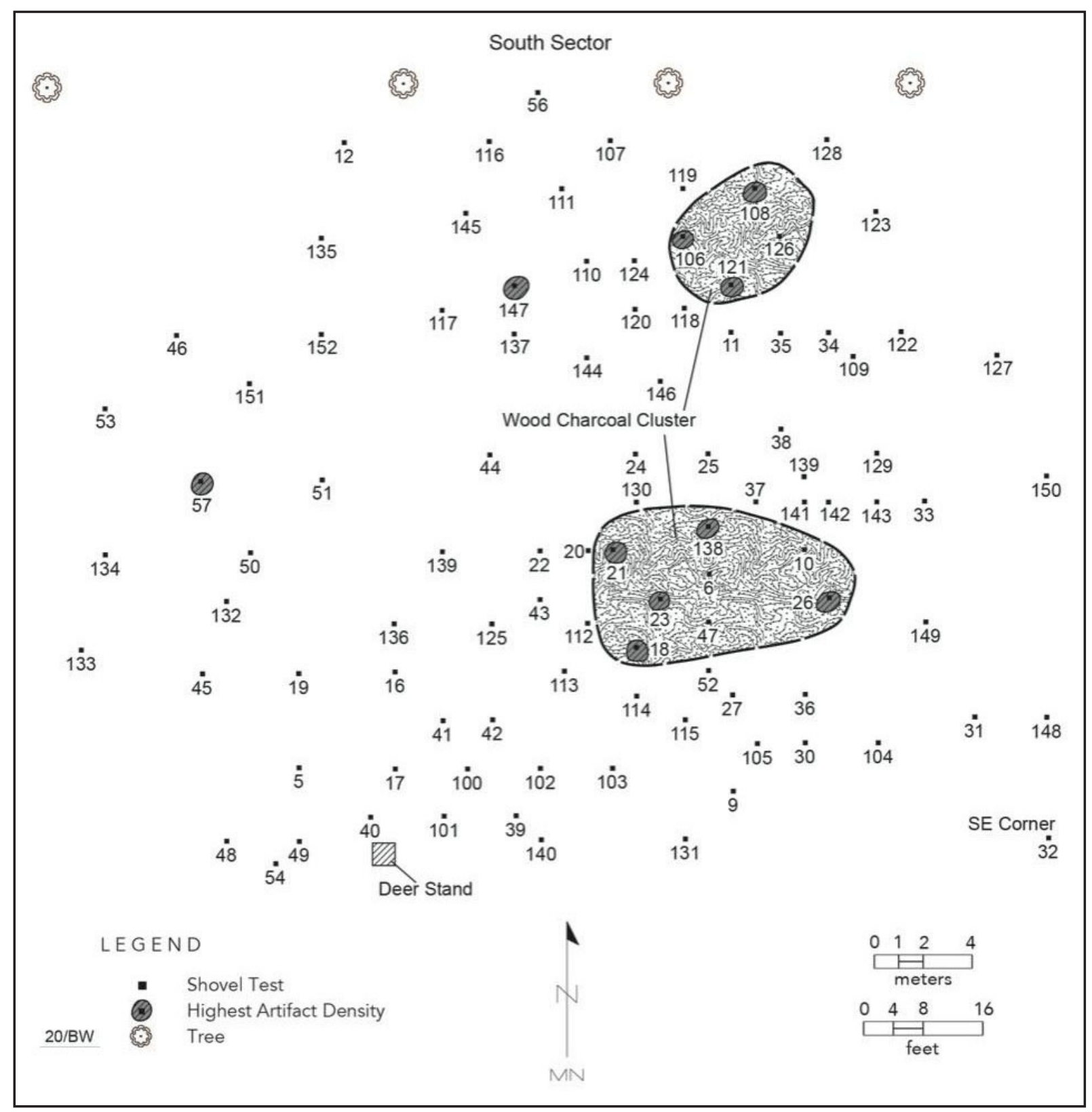

Figure 44. Distribution of wood charcoal pieces in South sector shovel tests.

of the nutshell samples are A.D. 1260-1299 (97.3 percent) and A.D. 1241-1293 (95.9 percent), and less so at A.D. 1306-1363 (59.7 percent) and A.D. 1341-1395 (58.3 percent). The splits in the 2 sigma calibrated age ranges between A.D. 1241-1299 and A.D. 1306-1395 suggest there may have been two different periods of use of the Long site by Caddo peoples in the $13^{\text {th }}$ and $14^{\text {th }}$ centuries A.D.

We had thought (and hoped) that the charred hickory nutshells chosen for radiocarbon dating at the Long site would be associated with the Early Caddo period component at the site, which was clearly the principal component based on the analysis of temporally diagnostic ceramic sherds and arrow points. Such was not the case, however. The best bet now to obtain absolute dates on the age of the Early Caddo period component at the Long site is to identify and excavate in a controlled 


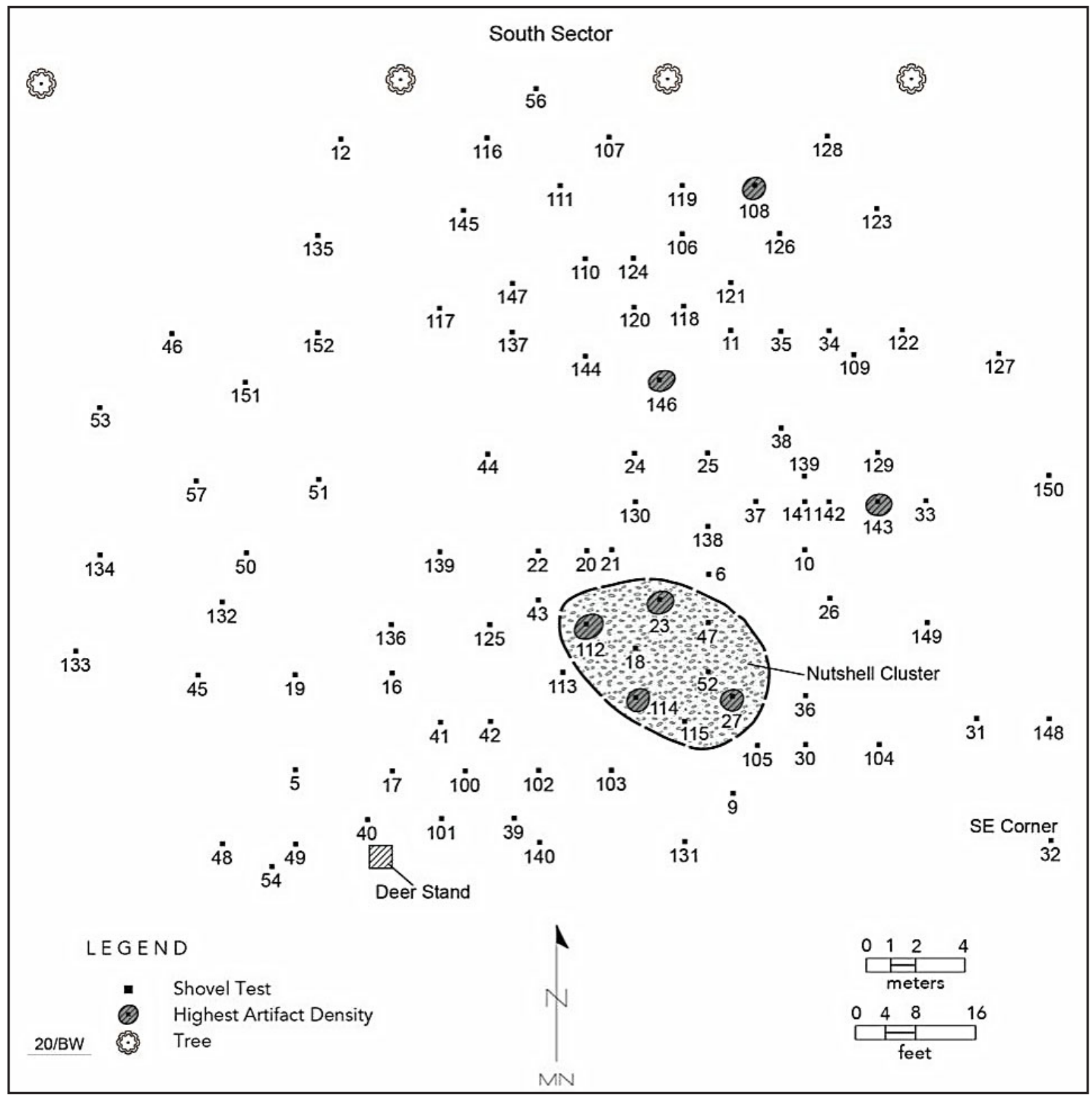

Figure 45. Distribution of charred nutshells in South sector shovel tests.

manner discrete cultural features that contain only temporally diagnostic artifacts of the period in their feature fill. Such work remains to be done at the site.

\section{Historic Artifact Assemblage}

The Joseph Holcomb family settled on Box's Creek in 1845, and at one time owned 1,000 acres of land in Cherokee County, Texas (https://texashistory.unt.edu/ark:/67531/metapth354360/m1/349/, accessed November 25,2019$)$. This land was in the vicinity of the $19^{\text {th }}$ century community of Box's Fort established in the 1830s by the Box family. Box's Fort was a log fort with an enclosure that held a log house and a dugout (https://texashistoricaalmarkers.weebly.com/boxes-fort.html, accessed November 25, 2019). Joseph and Sally Holcomb and their many children built houses on the property by the time of the Civil War, but the location of the original 1845 Holcomb family $\log$ 


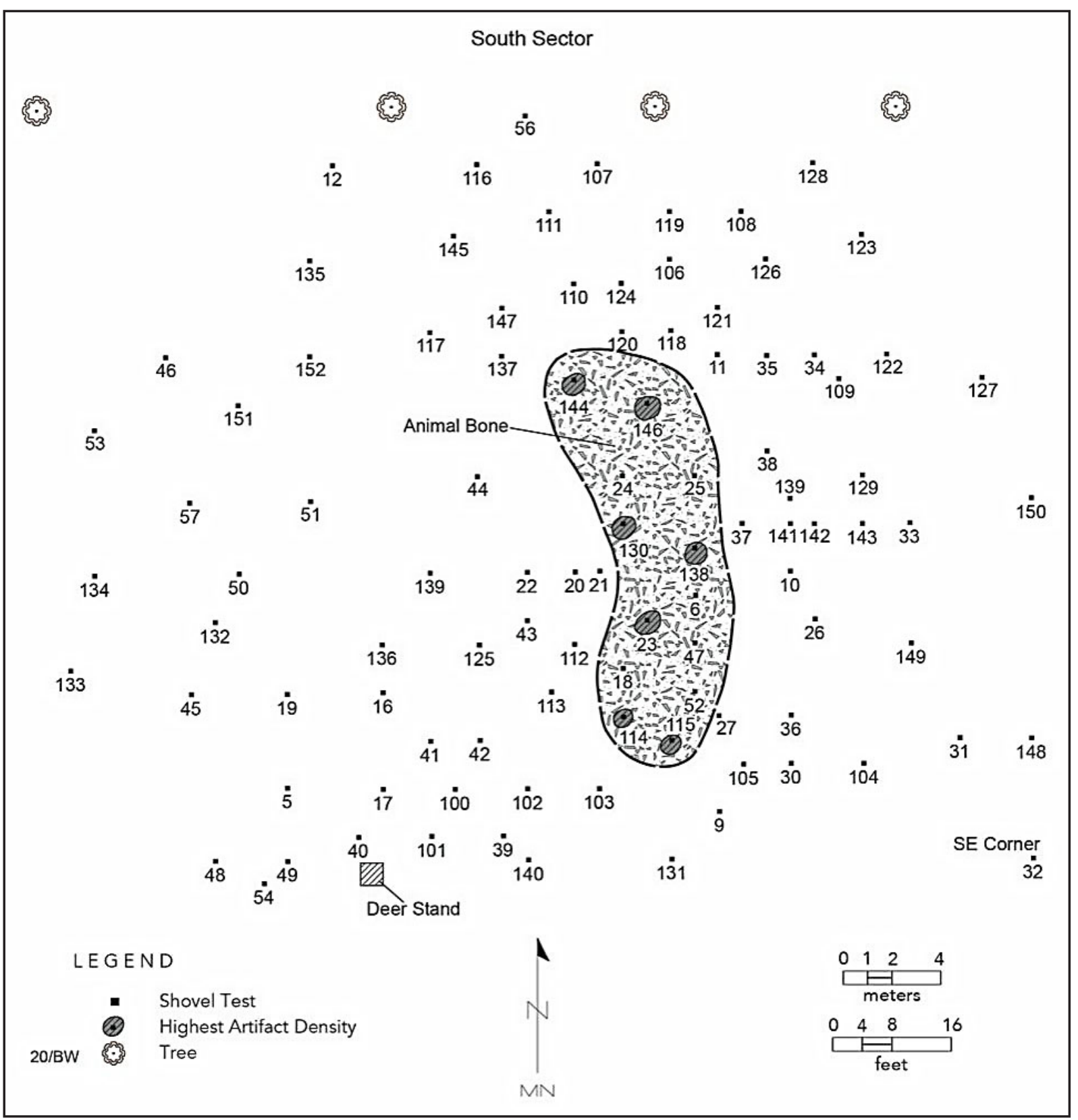

Figure 46. Distribution of burned animal bones in South sector shovel tests.

cabin is not known. Joseph (1796-1881) and his wife Sarah (died in 1870) are buried in Holcomb Cemetery on the Holcomb land on FM 2322 about $1.1 \mathrm{~km}$ west-northwest of the Long site.

Mr. Long knows of one of the Holcomb homesteads on his property about halfway between the Long site and the Holcomb cemetery, and he had found fire place bricks and other historic artifacts from an old house at that place; the age of these remains is not known (Larry Long, November 25, 2019 personal communication), but this area will be examined in future archaeological investigations on the Long propoerty. He also knows of another Holcomb house 150 yards south of the Holcomb cemetery; that house burned down, and the Holcomb's then built a house on the east side of Box's Creek. 
Table 23. Results of the radiocarbon dating of organic remains from the Long site.

\begin{tabular}{|c|c|c|c|c|}
\hline Sample \# & Direct-AMS \# & $\begin{array}{l}\text { Conventional age } \\
\text { (B.P.) }\end{array}$ & $\begin{array}{l}1 \text { Sigma } \\
\text { Calibration } \\
\text { (A.D.) and } \\
\text { probability }\end{array}$ & $\begin{array}{l}2 \text { Sigma } \\
\text { Calibration } \\
\text { (A.D.) and } \\
\text { probability }\end{array}$ \\
\hline CE330-1 & D-AMS 036775 & $714 \pm 25$ & $\begin{array}{l}\text { A.D. 1271- } \\
1288(1.00)\end{array}$ & $\begin{array}{l}\text { A.D. 1260- } \\
1299(0.973)\end{array}$ \\
\hline \multicolumn{5}{|c|}{ Median probability: A.D. 1279} \\
\hline CE330-2 & D-AMS 036776 & $569 \pm 28$ & $\begin{array}{l}\text { A.D. } 1321- \\
1349(0.588) \\
\text { A.D. } 1392- \\
1411(0.412)\end{array}$ & $\begin{array}{l}\text { A.D. 1306- } \\
1363(0.597) \\
\text { A.D. } 1385 \\
1422(0.403)\end{array}$ \\
\hline \multicolumn{5}{|c|}{ Median probability: A.D. 1348} \\
\hline CE330-3 & D-AMS 036777 & $637 \pm 27$ & $\begin{array}{l}\text { A.D. 1294- } \\
1314(0.38) \\
\text { A.D. 1356- } \\
1388(0.62)\end{array}$ & $\begin{array}{l}\text { A.D. 1285- } \\
1328(0.417) \\
\text { A.D. 1341- } \\
1395(0.583)\end{array}$ \\
\hline \multicolumn{5}{|c|}{ Median probability: A.D. 1353} \\
\hline CE330-4 & D-AMS 036778 & $736 \pm 29$ & $\begin{array}{l}\text { A.D. 1262- } \\
1283(1.00)\end{array}$ & $\begin{array}{l}\text { A.D. 1224- } \\
1235(0.041) \\
\text { A.D. 1241- } \\
1293(0.959)\end{array}$ \\
\hline
\end{tabular}

Median probability: A.D. 1271

The shovel testing in the South sector recovered 78 historic artifacts, likely dating to the mid$19^{\text {th }}$ century, and therefore likely to be associated with early Holcomb family settlements in the Box's Creek valley. The density of the historic artifacts in the positive shovel tests with historic artifacts is 2.69 , or ca. 21.5 artifacts per square meter of the archaeological deposits. A total of 29 shovel tests in the South sector have historic artifacts (Table 24), with north and south clusters (Figure 47) each covering ca. 150 square meters in the South sector.

Both the northern and southern clusters of historic artifacts are roughly comparable in the kinds of artifacts found in each, and these artifacts suggest these two clusters represent the locations of different wood structures built with cut nails (see Figure 47) and with associated scatters of discarded and broken artifacts, likely distributed outside of the two postulated structure locations. Each have numbers of bottle glass sherds from different bottles, whiteware sherds, stoneware sherds, cut nails, and unidentified iron fragments (see Table 24); pieces of slate were found only in the southern part of 
the South sector. With the exception of one iron strap fragment $(20-40 \mathrm{~cm} \mathrm{bs})$ in the southern part of the South sector, all the historic artifacts from this part of the site are from 0-20 cm bs.

Bottle glass sherds from the South sector comprise 35 percent of the recovered historic artifacts (see Table 24). The bottle glass came from pre-1870 bottles of different colors made by hand (see Jones and Sullivan 1985; Hunt 2008), including clear, aqua, yellow, amber, blue, and olive green. These bottles held foodstuffs, medicines, wine, beer, or snuff.

Ceramic sherds from plates and other tableware include nine plain whiteware or refined earthenware rim and body sherds, one plain ironstone (dense and semi-vitrified paste), and plain porcelain. Also in the South sector assemblage are five sherds of alkaline-glazed stone ware, made between ca. 1839-1875 in East Texas (Greer 1981; Lebo 1987:141), one salt-glazed stoneware sherd, also manufactured locally by the mid- $19^{\text {th }}$ century, and two 1840 s- 1850 s Rockingham stoneware sherds (Goldberg 2003).

Square cut or common cut nails between 7-12 pennyweight were recovered in the shovel testing in the South sector ( $n=15$, see Table 24). Cut nails were manufactured in the U.S. between 18201891 (Wells 1998). These nails indicate that a wood structure or two were built on the site, likely log Table 24. Historic artifacts from South sector shovel tests and clusters at the Long site.

$\begin{array}{lllllllllll}\text { ST No. } & \text { BG } & \text { IR } & \text { WW } & \text { P } & \text { SW } & \text { Cut } & \text { Iron } & \text { Slate } & \text { Ot* } & \text { N } \\ & \text { Nail } & \text { frags. } & \text { pieces }\end{array}$

\begin{tabular}{|c|c|c|c|c|c|c|c|c|c|c|}
\hline \multicolumn{11}{|c|}{ Northern cluster } \\
\hline ST 25 & - & - & - & - & - & - & - & 1 & - & 1 \\
\hline ST 106 & - & - & - & - & - & 1 & - & - & - & 1 \\
\hline ST 109 & - & - & - & - & - & - & - & 1 & - & 1 \\
\hline ST 118 & 2 & - & - & - & - & 1 & - & - & - & 3 \\
\hline ST 122 & 1 & - & - & - & - & 1 & - & - & - & 2 \\
\hline ST 123 & 2 & - & - & - & - & 1 & - & 1 & - & 4 \\
\hline ST 124 & 1 & - & - & - & - & - & - & 1 & - & 2 \\
\hline ST 126 & 1 & - & - & - & - & - & - & 1 & - & 2 \\
\hline ST 127 & - & - & - & - & - & 1 & - & - & - & 1 \\
\hline ST 128 & - & - & - & - & 2 & - & - & - & - & 2 \\
\hline ST 146 & 2 & - & 1 & - & - & 3 & 1 & - & - & 7 \\
\hline Subtotal & 9 & - & 1 & - & 2 & 8 & 1 & 5 & - & 26 \\
\hline \multicolumn{11}{|c|}{$\underline{\text { Southern cluster }}$} \\
\hline ST 6 & - & - & - & - & - & - & - & - & 2 & 2 \\
\hline ST 23 & 1 & - & 2 & - & - & - & 3 & - & 1 & 7 \\
\hline ST 27 & - & - & - & - & - & 2 & - & - & - & 2 \\
\hline ST 30 & 2 & 1 & - & - & - & 1 & 2 & - & - & \\
\hline \multicolumn{11}{|l|}{6} \\
\hline ST 36 & 1 & - & 3 & 1 & 5 & - & - & - & - & 10 \\
\hline ST 39 & 1 & - & - & - & - & - & - & - & - & 1 \\
\hline ST 52 & - & - & - & - & - & 1 & - & - & - & 1 \\
\hline
\end{tabular}


Table 24. Historic artifacts from South sector shovel tests and clusters at the Long site, cont.

\begin{tabular}{|c|c|c|c|c|c|c|c|c|c|c|}
\hline ST No. & $\begin{array}{l}\text { BG } \\
\text { Nail }\end{array}$ & $\begin{array}{l}\text { IR } \\
\text { frags. }\end{array}$ & $\begin{array}{l}\text { WW } \\
\text { pieces }\end{array}$ & $\mathrm{P}$ & SW & Cut & Iron & Slate & $\mathrm{Ot}^{*}$ & $\mathrm{~N}$ \\
\hline ST 102 & - & - & - & - & - & - & 1 & - & - & 1 \\
\hline ST 104 & 4 & - & - & - & - & 1 & - & - & - & 5 \\
\hline ST 112 & 2 & - & - & - & - & - & - & - & - & 2 \\
\hline ST 113 & - & - & - & - & - & 1 & - & - & - & 1 \\
\hline ST 114 & 2 & - & - & - & - & - & - & - & 1 & 3 \\
\hline ST 115 & 4 & - & 1 & - & - & - & - & - & - & 5 \\
\hline Subtotal & 17 & 1 & 6 & 1 & 5 & 6 & 6 & - & 4 & 46 \\
\hline \multicolumn{11}{|c|}{ Not in clusters } \\
\hline ST 45 & - & - & 1 & - & - & - & - & - & 1 & 2 \\
\hline ST 46 & 1 & - & - & - & - & - & - & - & - & 1 \\
\hline ST 137 & - & - & - & - & 1 & - & - & - & - & 1 \\
\hline ST 141 & - & - & - & - & - & 1 & - & - & - & 1 \\
\hline ST 142 & - & - & 1 & - & - & - & - & - & - & 1 \\
\hline Subtotal & 1 & - & 2 & - & - & 1 & - & - & 1 & 5 \\
\hline Totals & 27 & 1 & 9 & 1 & 8 & 15 & 7 & 5 & 5 & 78 \\
\hline
\end{tabular}

BG=bottle glass; $\mathrm{IR}=$ ironstone; $\mathrm{WW}=$ whiteware; $\mathrm{P}=$ porcelain; $\mathrm{SW}=$ stoneware; $\mathrm{Ot}=$ other, including an iron horseshoe and an iron container rim in ST 6; a clay marble in ST 23; an earthenware pipe sherd in ST 45; and an iron kettle fragment in ST 114

pen buildings. These nails were used for major construction efforts, including framing and siding, as well as to support joists and sills.

Other iron artifacts in the South sector include an iron strap and iron fragments $(n=6)$. There also is an iron horseshoe fragment in the assemblage, with one common cut horseshoe nail (see Spivey et al. 1977) still attached to the shoe, and pieces from a cast iron kettle (see Perttula et al. 2016:Figure 26e-f).

The remainder of the recovered historic artifacts are a clay marble, an unglazed earthenware pipe rim sherd, possibly a mid- $19^{\text {th }}$ century reed stem pipe, and five pieces of dark gray slate. These flat and smoothed pieces are from a slate board.

In contrast to the South sector, where historic artifacts are relatively common in some parts of the sector (see Figure 47), only two historic artifacts were recovered in the shovel testing in the North sector, both from ST 175 in the northeastern part of the sector (see Figure 12). These were an iron spike fragment (0-20 cm bs) and a broken square or cut nail (1820-1891), probably used in joist and sills construction for a log building. The broken cut nail is at least 4.1 inches in length. 


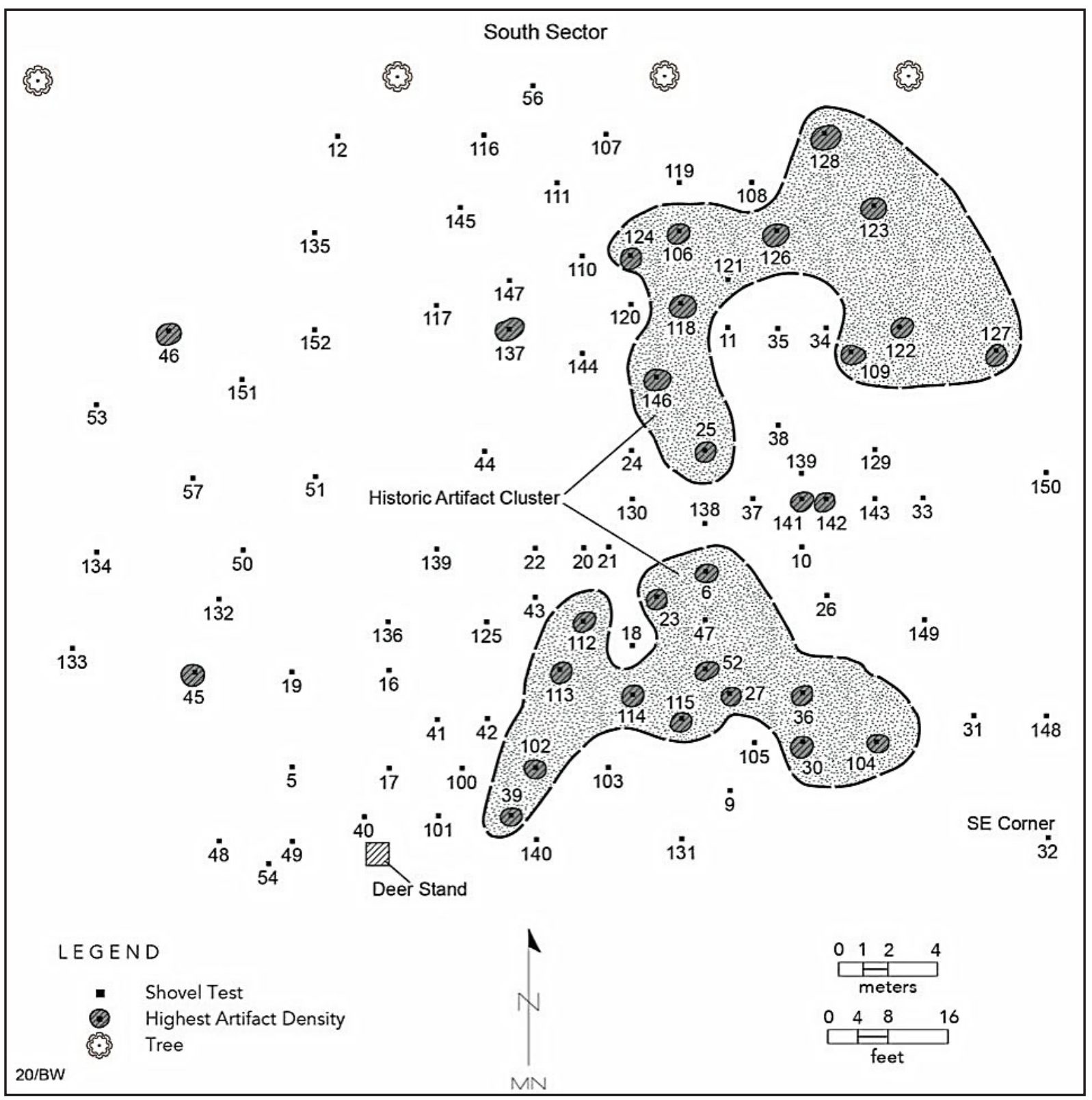

Figure 47. Distribution of historic artifacts in shovel tests in the South sector.

\section{Summary and Conclusions}

The Long site is a multi-component archaeological deposit on an alluvial terrace on the west side of Box's Creek in Cherokee County, Texas. Box's Creek is a southward-flowing tributary to the Neches River in the East Texas Pineywoods. The components recognized at the site include Late Paleoindian, Late Archaic, Mossy Grove Woodland period, Early Caddo and Alto phase (see Story 2000:Figure 5) - by far the principal component-Middle Caddo (with median probability radiocarbon dates that range from A.D. 1271-1353), and a mid-19 ${ }^{\text {th }}$ century Anglo-American settlement with log pen structures. These components cover at most ca. 1 acre of the alluvial terrace, and a large chunk of the site was disturbed and destroyed by the construction of a buried oil pipeline and a related oil well pad berm. 
As best as can be determined from the available archaeological record, the Long site was a domestic settlement probably occupied year-round for some years during the Alto phase occupation, as evidenced by the high density of recovered artifacts in the South sector positive shovel tests, but was only periodically used by Native Americans at other times, extending back to more than 10,000 years ago. Shovel testing data suggests that cultural features are preserved in the archaeological deposits, which ranges from $0-60 \mathrm{~cm}$ bs in depth. Spatial data on the distribution and concentration of recovered artifacts, especially the ceramic sherds, suggest that there may be the remnants of 3-4 ancestral Caddo structure and activity area clusters in the South sector. Further archaeological investigations are warranted to examine each of these areas to determine the character and distribution of such preserved cultural features and their associated artifacts.

The Early Caddo material culture preserved at the Long site primarily includes sherds from plain, utility, and fine ware ceramic types. Among the utility wares are Crockett Curvilinear Incised, Davis Incised, Dunkin Incised, Evansville Punctated, Hollyknowe Ridge Pinched, Kiam Incised, Pennington Punctated-Incised, Weches Fingernail Impressed, and Wilkinson Punctated sherds, and Holly Fine Engraved, Hickory Engraved, and Spiro Engraved fine wares.

The Long site and the George C. Davis site share a common suite of identified ceramic types (Table 25), although the George C. Davis sample size from a large mound and village dwarfs the much more modest sample of decorated sherds by type from the Long site. Holly Fine Engraved and Dunkin Incised are the most abundant types in use at both sites, followed by Weches Fingernail Impressed and Davis Incised. Only sherds from Crockett Curvilinear Incised and Pennington Punctated-Incised vessels are apparently much more common at George C. Davis (7-11 percent of the assemblage) than they are at the Long site (2-4 percent) (Table 25). From these data, it seems clear that more or less the full range of Alto phase utility and fine ware ceramics were in use at both the large mound center as well as the small and nearby domestic settlement.

Table 25. Identified and shared ceramic types from the George C. Davis site (from Stokes and Woodring 1981: Table 26) and the Long site.

Type

GCD Site

Long Site

Holly Fine Engraved

4280

34

Hickory Engraved

600

10

Crockett Curvilinear Incised

1637

5

Pennington Punctated-Incised

1057

3

Dunkin Incised

3606

34

Davis Incised

1255

22

Weches Fingernail Impressed

2021

25

Duren Neck Banded

291

$-$

Totals

14,747

133 
There is also a long-stemmed Red River ceramic pipe sherd in the assemblage, along with a welldeveloped chipped stone and ground stone industry with Alba arrow points and preforms, expedient flake tools and a scraper, and manos, metates, and pitted stones used in processing plant food remains. Much of the chipped stone tools and associated lithic debris are on non-local raw materials, primarily cherts from Central Texas sources as well as Manning Fused Glass. Charred plant remains (wood charcoal and charred hickory nutshells) and burned animal bones are not well preserved in the archaeological deposits, and even though they are spatially associated with the aforementioned likely structure and activity area clusters in the South sector, they actually date later in time, in the $13^{\text {th }}$ and $14^{\text {th }}$ centuries A.D.

Story (2000:20) had noted some years ago that "No Alto phase sites have been found near Davis and, in fact, components of this phase are no where common." Story (2000:23) further stated that "[e]vidently most of the Alto phase folk resided at either the Davis or Hudnall-Pirtle civic/ ceremonial centers. Perhaps the smaller settlements are primarily special camps or extraction sites." The Long site is near to the George C. Davis site, and only ca. $10 \mathrm{~km}$ separates the two sites. The apparent character of the Long site and the diversity of recovered material culture remains there suggests that it is not a special camp or extraction site but a residential site where ancestral Caddo people lived for a time; these people were closely affiliated with the village and mound center at the George C. Davis site on the Neches River.

Components of the Alto phase are known in the Neches, Angelina, and Sabine River basins in East Texas and Northwest Louisiana, over a ca. 6300 square mile area of the Pineywoods (see Story 2000:Figure 5). There is an abundance of archaeological information available on the Formative (ca. A.D. 800/850-1000) and Early (ca. A.D. 1000-1200) Caddo period occupation of the Pineywoods of East Texas, but the archaeological record for these periods is relatively sparse in the Neches River basin outside of the George C. Davis site itself. Caddo sites of these ages appear to be situated primarily on elevated landforms (alluvial terraces and rises, natural levees, and upland edges) adjacent to the major streams, as well as along minor tributaries and spring-fed branches. Proximity to arable sandy loam soils were preferred for settlement locations, presumably because of good drainage for habitation, and for cultivation purposes. The majority of these Caddo sites may be permanent settlements with some evidence of the structures, including posts, pits, and features, marking their multi-year residency, along with cemeteries and graves where the dead were buried; the middens where the animal and plant food refuse was discarded amidst broken stone tools and pottery vessels; and the material remains of tools and ceramics used in the procurement and processing of the bountiful resources of the region. They represent the settlements of Caddo communities and sociopolitical entities, and the civic-ceremonial centers at the George C. Davis site on the Neches, and the Hudnall-Pirtle (41RK4, Bruseth and Perttula 2006) and Boxed Springs (41UR30, Perttula 2011) sites on the Sabine River, that were their focus.

The distribution of Caddo settlements across the landscape suggests that most habitats were used to some extent, either intensively as locations for the sedentary communities and farmsteads (that may have been occupied for single or multiple generations) in widely dispersed communities, in proximity to arable soils, or periodically by groups in logistical camps where specific natural resources could be procured by the Caddo in bulk. The most common types of Caddo settlements in the region during these periods of time appear to be small year-round hamlets and farmsteads with circular to rectangular structures. These settlements sometimes occur in association with small household cemeteries, and occasionally with a larger cemetery (> 10 burials).

In at least one instance, an Early Caddo period cemetery at the Joe Meyers Estate \#1 site (41SM73) in the upper Neches River basin in Smith County, Texas, contains the burial of socially elite individuals in a family and/or village cemetery context (Perttula 2015). This particular burial 
had four individuals with associated ceramic vessels as funerary offerings; there were six other interments with single individuals.

Larger communities (covering more than 10 acres) have also been recognized that occur in association with mound centers, such as the large settlements at George C. Davis and HudnallPirtle. These mound centers have extensive habitation areas, plazas, and spatially restricted temple and burial mound locales. Shaft burials of high status individuals have been documented in mound contexts at the George C. Davis site (Story 1997, 1998, 2000) and a few other mound centers in the Sabine and Angelina river basins.

Certainly the most thoroughly studied Early Caddo period Alto phase site in the region is the George C. Davis site, a large village and mound center on the Neches River, $10 \mathrm{~km}$ downstream from the Long site. Remote sensing investigations indicate that there are more than 100 structures in the village areas around the three mounds on site (Creel et al. 2005; Walker and McKinnon 2012). Calibrated radiocarbon dates from village contexts establish that the site was occupied beginning by the mid-ninth century A.D., and then was continuously settled to the end of the 13th century A.D. (Story 2000), apparently overlapping in age with the Middle Caddo period remains at the Long site. A large number of structures were built on, and adjacent to, Mound A, one of the flat-topped platform mounds, and the extensive structure rebuilding there indicates the area was preferred for settlement by the Caddo. There were three mounds at the Davis site, including Mound A, Mound $\mathrm{C}$ (burial mound) built over a large pre-mound burial pit in the latter part of the Formative Caddo period and containing an estimated 25-30 elite burial pits, and Mound B (a second flat-topped platform) constructed about A.D. 1200 or slightly earlier (Story 1997, 1998).

The larger sites like Hudnall-Pirtle and Boxed Springs are important civic-ceremonial centers containing multiple mounds and associated villages in their own right, and these generally date after ca. A.D. 900, contemporaneous with the George C. Davis mound center. The Boxed Springs (four mounds, village, and large cemetery), and Hudnall-Pirtle (eight mounds and 60-acre village) multiple mound centers appear to represent the apex of postulated local Early Caddo Alto phase networks in the Sabine River basin. The distribution, number, and spacing of mound centers, particularly the sites with multiple mounds, in East Texas and adjoining parts of southwestern Arkansas and northwestern Louisiana, clearly indicates that the Caddo peoples who built and used these mounds were integrated into societies of considerable socio-political complexity.

These Formative to Early Caddo groups were horticulturists, cultivating maize and squash, along with several kinds of native seeds (Perttula 2008), gathered nuts and tubers/storage roots, and were proficient hunters of deer, fish, and many other animal species. The available paleobotanical and bioarchaeological evidence (including stable carbon isotopes on human remains) from East Texas (and elsewhere in the Caddo area, including the Neches River basin) indicates, however, that Caddo groups became dependent upon maize and other domesticated crops until after about A.D. 1300; only by ca. A.D. 1450 did maize likely comprised more than 50 percent of the diet (see Wilson 2012; Wilson and Perttula 2013).

The Formative and Early Caddo period groups possessed a rich material culture. Well-made, corner-notched, and rectangular-stemmed arrow points were common, along with siltstone and greenstone celts, perforators and borers, large Gahagan bifaces (Selden et al. 2018), and a variety of more expedient stone tools (unifacial flake scraping and cutting implements). Long-stemmed Red River (Hoffman 1967) and cigar-shaped ceramic pipes were made by the Caddo at this time, as were ceramic ear spools and figurines (see Newell and Krieger 1949). 
The most distinctive material culture item of the Alto phase Caddo groups were the ceramics they made for cooking, storage, and serving needs. The styles and forms of ceramics found on sites in the region hint at the variety, temporal span, and geographic extent of a number of ancestral Caddo groups spread across the landscape. The diversity in decoration and shape in Caddo ceramics is substantial, both in the utility ware jars and bowls, as well as in the fine ware bottles, carinated bowls, and compound vessels. A diverse and distinctive ceramic assemblage characterizes the Caddo ceramics from the region. Ceramics are quite common in domestic contexts on habitation sites across the region and also occur as grave goods in mortuary contexts.

The pottery types identified in the decorated sherds and vessels known to come from ca. A.D. 850-1200 East Texas Caddo sites such as George C. Davis include: (a) the engraved fine ware types Hickory Engraved, Holly Fine Engraved, and Spiro Engraved, and (b) the utility ware types Coles Creek Incised, Davis Incised, Dunkin Incised, Weches Fingernail Impressed, Kiam Incised, East Incised, Hollyknowe Ridge Pinched, Crockett Curvilinear Incised, Pennington Punctated-Incised, Duren Neck Banded, and Crenshaw Fluted. All of these types would be expected to be present in ca. A.D. 850/900-1200 Caddo sites in East Texas, along with several other types, but the relative proportions of the different ceramic types vary from site to site and through time across the region. Fine ware engraved vessels dominate the vessel collections at both Boxed Springs (41UR30) and George C. Davis sites, particularly Hickory Engraved and Holly Fine Engraved, as well as Spiro Engraved. In these Early Caddo sherd assemblages, engraved fine wares comprise between 16.530.8 percent of all the decorated sherds; red-slipped sherds are rare. At the Long site, engraved sherds account for 14.9 percent of the decorated sherds.

East Texas Caddo fine wares dating before ca. A.D. 1200 have curvilinear, rectilinear, and horizontal decorative elements and motifs, with dominant geometric patterns as well as scrolls, and frequently cover the entire vessel surface; other fine ware designs simply are placed on the rim, or sometimes on the interior rim surface. The earlier Caddo fine wares are quite uniform in style and form, suggesting that a broad and extensive social interaction existed between Caddo groups across East Texas, in concert with an extensive trade and exchange of vessels.

The most common decorative methods on ca. A.D. 850-1200 East Texas Caddo utility ware vessels, and on sherds from vessels, are incised (especially horizontal incised elements), punctated, and incised-punctated designs. Crockett Curvilinear Incised and Pennington Punctated Incised sherds and vessels are present in pre-A.D. 1200 ceramic assemblages, but occur in considerable frequencies only at the George C. Davis site; they are rare (2.1 percent of the decorated sherds) at the Long site. An analysis of the ceramic assemblages from well-dated unit excavations at the site (see Stokes and Woodring 1981:Table 26), suggests that both types are present in unit excavations that date from cal. A.D. 897-1276, virtually the entire span of the ancestral Caddo occupation (see Story 2000), with Crockett Curvilinear Incised most common between cal. A.D. 1027-1223 and Pennington Punctated Incised most common throughout the occupation at the site.

Some vessels have horizontal incised lines above rows of vertically oriented punctations, and have straight or parallel incised lines adjacent to a zone of tool punctations. Rows of tool punctations also occur between the incised lines. This decorative element is noted in ceramic assemblages at Early Caddo sites like Hudnall-Pirtle (41RK4) and George C. Davis in East Texas (Newell and Krieger 1949:Figure 38m-n; Bruseth and Perttula 2006:Figure 26d; Perttula 2011, ed.:Figures 35b and 36a) and Northwest Louisiana (see Webb 1963:Figure 9r-s, u). 
Coles Creek Incised sherds and vessels are present in very low frequencies in several Early Caddo sites in East Texas. At the George C. Davis site, for example there are only nine Coles Creek Incised sherds in an assemblage of more than 100,000 sherds and 15 whole vessels (Story et al. 1990:746); there are no identified Coles Creek Incised sherds at the Long site. The occurrence and relative proportion of Coles Creek Incised pottery in ceramic assemblages from the Early Caddo Mound Pond site (41HS12) near Caddo Lake is considerable, however, dwarfing its use on most East Texas Caddo sites of the same age (Goode et al. 2015). The most common variety is var. Coles Creek (Phillips 1970), and this variety apparently dates from ca. A.D. 900-1050 in Formative to Early Caddo contexts (Girard 2009:52). The Coles Creek Incised vessels and sherds from sites in the Caddo area are similar "in decorative designs and sometimes in vessel form, but not usually in details of paste" (Story et al. 1990:736) to vessel sherds in the Lower Mississippi Valley. They do not represent settlement of the area by Lower Mississippi Valley peoples. Girard (2009:52) suggests there was a period of strong Lower Mississippi Valley Coles Creek contact and social interaction among Caddo peoples in parts of the Caddo area between ca. A.D. 900-1050.

Early Caddo plain ware vessels include bottles, bowls, carinated bowls, and jars. The relatively high frequency of plain rims (47.6 percent) among all the rim sherds in habitation deposits at the

Early Caddo Boxed Springs site indicate that plain vessels comprise a substantial part of the vessels made and used by the Caddo inhabitants of the site. More than 42 percent of the 169 vessels in the Boxed Springs cemetery were also plain wares (Perttula 2011 (editor):Table 11).

The Caddo potters made ceramics at this time in a wide variety of vessel shapes, and with an abundance of well-crafted and executed body and rim designs and surface treatments. There is an impressive diversity of vessel forms among the Caddo fine wares. This includes carinated bowls, deep compound bowls, double and triple vessels (joined bowls and bottles [Suhm and Jelks 1962:Plates 38k, 51e, 59d]), bottles, ollas, zoomorphic and anthropomorphic effigy bowls and bottles, ladles, platters, peaked jars, gourd and box-shaped bowls, and chalices. From the archaeological contexts in which Caddo ceramics have been found, as well as inferences about their manufacture and use, it is evident that ceramics were important to the prehistoric Caddo in: the cooking and serving of foods and beverages, in the storage of foodstuffs, as personal possessions, as beautiful works of art and craftsmanship (i.e., some vessels were clearly made to never be used in domestic contexts but only in ritual contexts), and as social identifiers; that is, certain shared and distinctive stylistic motifs and decorative patterns marked closely related communities and constituent groups. The principal occupation at the Long site appears to be closely related to the Alto phase community centered at the George C. Davis site in the $10^{\text {th }}-13^{\text {th }}$ centuries A.D.

\section{Acknowledgments}

We thank the landowner for permission to conduct this archaeological survey/shovel testing investigation at the Long site, and for allowing us to study and document the recovered artifacts from the site. Brian Wootan prepared many of the figures in this article, Lance Trask prepared Figure 1 , and the remainder of the photographs were taken by Kevin Stingley.

\section{References Cited}

Black, S. L. and A. V. Thoms

2014 Hunter-Gatherer Earth Ovens in the Archaeological Record: Fundamental Concepts. American Antiquity 79(2):203-226. 
Brown, K. M.

1976 Fused Volcanic Glass from the Manning Formation. Bulletin of the Texas Archeological Society 47:189-207.

Bruseth, J. E. and T. K. Perttula

2006 Archeological Investigations at the Hudnall-Pirtle Site (41RK4): An Early Caddo Mound Center in Northeast Texas. Caddo Archeology Journal 15:57-158.

Creel, D., D. Hudler, S. Wilson, C. Schultz, and C. Walker

2005 A Magnetometer Survey of Caddoan Mounds State Historic Site. Technical Report 51. Texas Archeological Research Laboratory, The University of Texas at Austin.

Diggs Jr., G. M., B. L. Lipscomb, M. D. Reed, and R. J. O’Kennon

2006 Illustrated Flora of East Texas, Volume One: Introduction, Pteridophytes, Gymnosperms, and Monocotyledons Sida, Botanical Miscellany, No. 26. Botanical Research Institute of Texas, Fort Worth.

Gearhart, R. L.

1997 East Texas Electric Cooperative, Inc. Cultural Resources Survey (Slocum-Alto Segment), Anderson and Cherokee Counties, Texas. Document No. 970334. Espey, Huston \& Associates, Inc., Austin.

Girard, J. S.

2009 Comments on Caddo Origins in Northwest Louisiana. Journal of Northeast Texas Archaeology 31:51-60.

Girard, J. S., D. B. Kelley, and D. P. McKinnon

2020 Caddo Ceramics in the Red River Basin in Northwest Louisiana and Southwest Arkansas. In Ancestral Caddo Ceramic Traditions, edited by D. P. McKinnon, J. S. Girard, and T. K. Perttula. Louisiana State University Press, Baton Rouge, in press.

Goldberg, A. F.

2003 Highlights in the Development of the Rockingham and Yellow Ware Industry in the United States: A Brief Review with Representative Examples. Ceramics in America 2003 (https:/article.php/76/Ceramics-in-America-2003/Highlights-in-the-Development-of-theRockingham-and-Yellow-Ware-Industry-in-the-United States---A-Brief-Review-withRepresentative-Examples).

Goode, G. T., T. K. Perttula, L. L. Bush, S. Marceaux, L. Schniebs, and J. Todd

2015 Excavations at the Early Caddo Period Mound Pond Site (41HS12) in Harrison County, Texas. Special Publication No. 38. Friends of Northeast Texas Archeology, Austin and Pittsburg.

Greer, G.

1981 American Stonewares: The Art and Craft of Utilitarian Potters. Schiffer Publishing Limited, Exton, Pennsylvania.

Hart, J. P.

1982 An Analysis of the Aboriginal Ceramics from the Washington Square Mound Site, Nacogdoches County, Texas. Master's thesis, Department of Anthropology, Northeast Louisiana University, Monroe. 
2014 An Analysis of the Aboriginal Ceramics from the Washington Square Mound Site, Nacogdoches County, Texas. Stephen F. Austin State University Press, Nacogdoches.

Hoffman, M. P.

1967 Ceramic Pipe Style Chronology Along the Red River Drainage in Southwestern Arkansas. The Arkansas Archeologist 8(1):4-14.

Hunt, W. L., Jr.

2008 More than Meets the Eye: The Archeology of Bathhouse Row, Hot Springs National Park, Arkansas. Technical Report 102. Midwest Archeological Center, National Park Service, U.S. Department of the Interior, Lincoln.

Jones, O. and C. Sullivan

1985 The Parks Canada Glass Glossary for the Description of Containers, Tableware, Flat Glass, and Closures. Studies in Archaeology, Architecture and History, National Historic Parks and Sites Branch, Parks Canada, Environment Canada, Ottawa.

Lebo, S. A.

1987 Local Utilitarian Stonewares: A Diminishing Artifact Category. In Historic Buildings, Material Culture, and People of the Prairie Margin: Architecture, Artifacts, and Synthesis of Historic Archaeology, edited by D. H. Jurney and R. W. Moir, pp. 121-142. Richland Creek Technical Series, Vol. V. Archaeology Research Program, Southern Methodist University, Dallas.

Leith, L.

2014 Towards a Common Understanding: A Revision of Fourche Maline Chronology in Oklahoma. Caddo Archeology Journal 24:5-28.

Mowery, I. C.

1959 Soil Survey, Cherokee County, Texas. United States Department of Agriculture, Soil Conservation Service, in cooperation with Texas Agricultural Experiment Station, Washington. D.C.

Newell, H. P and A. D. Krieger

1949 The George C. Davis Site, Cherokee County, Texas. Memoir No. 5. Society for American Archaeology, Menasha, Wisconsin.

2000 The George C. Davis Site, Cherokee County, Texas. Second Edition. Society for American Archaeology, Washington, D.C.

Perttula, T. K.

2008 Caddo Agriculture on the Western Frontier of the Eastern Woodlands. Plains Anthropologist 53(205):79-105.

2013 Caddo Ceramics in East Texas. Bulletin of the Texas Archeological Society 84:181-212.

2015 The Joe Meyer Estate \#1 Site (41SM73) on Saline Creek in the Upper Neches River Basin in East Texas. Journal of Northeast Texas Archaeology 53:1-9.

2018 The Strawberry Hill Site (41SJ160) Ceramic Vessel Sherd Assemblage, San Jacinto County, Texas, and Comparisons to Other Mossy Grove Culture Ceramic Assemblages. Report No. 31. Houston Archeological Society, Houston. 
Perttula, T. K. (assembler)

2017 Specialized Ceramic Analyses of the George C. Davis Site (41CE19) Ceramic Assemblage, Cherokee County, Texas. Report of Investigations No. 146. Archeological \& Environmental Consultants, LLC, Austin.

Perttula, T. K. (editor)

2008 Lake Naconiche Archeology, Nacogdoches County, Texas: Results of the Data Recovery Excavations at Five Prehistoric Archeological Sites. 2 Vols. Report of Investigations No. 60. Archeological \& Environmental Consultants, LLC, Austin.

2011 Archaeological and Archaeogeophysical Investigations at an Early Caddo Mound Center in the Sabine River Basin of East Texas. Special Publication No. 15. Friends of Northeast Texas Archaeology, Austin and Pittsburg.

Perttula, T. K. and R. Z. Selden, Jr.

2014 Ancestral Caddo Ceramics in East Texas. Journal of Northeast Texas Archaeology 48:9-58.

Perttula, T. K., B. D. Skiles, and B. Nelson

2016 The Clear Creek Site (41BW698), an Early $19^{\text {th }}$ Century Settlement in the Red River Valley, Bowie County, Texas. Bulletin of the Texas Archeological Society 87:123-161.

Phillips, P.

1970 Archaeological Survey in the Lower Yazoo Basin, Mississippi, 1949-1955. 2 Parts. Papers of the Peabody Museum of Archaeology and Ethnology, Volume 60. Harvard University, Cambridge, Massachusetts.

Reimer P. J, E. Bard, A. Bayliss, J. W. Beck, P. G. Blackwell, C. Bronk Ramsey, C. E. Buck, H. Cheng, R. L. Edwards, M. Friedrich, P. M. Grootes, T. P. Guilderson, H. Haflidason, I. Hajdas, C. Hatté, T. J. Heaton, A. G. Hogg, K. A. Hughen, K. F. Kaiser, B. Kromer, S. W. Manning, M. Niu, R. W. Reimer, D. A. Richards, E. M. Scott, J. R. Southon, C. S. M. Turney, and $\mathrm{J}$. van der Plicht

2013 IntCal13 and MARINE13 radiocarbon age calibration curves 0-50000 years cal BP. Radiocarbon 55(4):1869-1887. DOI: 10.2458/azu_js_rc.55.16947.

Robinson, D. G.

2017 Ceramic Petrographic Analysis of Prehistoric Pottery from the George C. Davis Site (41CE19), Cherokee County, Texas. In Specialized Ceramic Analyses of the George C. Davis Site (41CE19) Ceramic Assemblage, Cherokee County, Texas, assembled by T. K. Perttula, pp. 13-52. Report of Investigations No. 146. Archeological \& Environmental Consultants, LLC, Austin.

Schambach, F. F.

1982 An Outline of Fourche Maline Culture in Southwest Arkansas. In Arkansas Archeology in Review, edited by N. L. Trubowitz and M. D. Jeter, pp. 132-197. Research Series No. 15. Arkansas Archeological Survey, Fayetteville.

Selden, R. Z., Jr., J. E. Dockall, and H. J. Shafer

2018 Lithic morphological organization: Gahagan bifaces from the Southern Caddo Area. Digital Applications in Archaeology and Cultural Heritage (2018).

Shafer, H. J. and M. Walters

2010 The Browning Site (41SM195A) Lithics: Considering Patterns of Identity and Interaction through Lithic Analysis. Bulletin of the Texas Archeological Society 81:127-151. 
Spivey, T., D. J. Crouch, C. R. Ferring, and K. Franklin

1977 Archeological Investigations along the Waurika Pipeline, Comanche, Cotton, Jefferson, and Stephens Counties, Oklahoma. Contributions No. 5. Museum of the Great Plains, Lawton, Oklahoma.

Stokes, J. and J. Woodring

1981 Native-Made Artifacts of Clay. In Archeological Investigations at the George C. Davis Site, Cherokee County, Texas: Summers of 1979 and 1980, edited by D. A. Story, pp. 135-238. Occasional Paper No. 1. Texas Archeological Research Laboratory, The University of Texas at Austin.

Story, D. A.

1997 1968-1970 Archeological Investigations at the George C. Davis Site, Cherokee County, Texas. Bulletin of the Texas Archeological Society 68:1-113.

1998 The George C. Davis Site: Glimpses into Early Caddoan Symbolism and Ideology. In The Native History of the Caddo: Their Place in Southeastern Archeology and Ethnohistory, edited by T. K. Perttula and J. E. Bruseth, pp. 9-43. Studies in Archeology 30. Texas Archeological Research Laboratory, The University of Texas at Austin.

2000 Introduction. In The George C. Davis Site, Cherokee County, Texas, by H. P. Newell and A. D. Krieger, pp. 1-31. 2nd Edition. Society for American Archaeology, Washington, D.C.

Story, D. A., J. A. Guy, B. A. Burnett, M. D. Freeman, J. C. Rose, D. G. Steele, B. W. Olive, and K. J. Reinhard

1990 The Archeology and Bioarcheology of the Gulf Coastal Plain. 2 Vols. Research Series No. 38. Arkansas Archeological Survey, Fayetteville.

Stuiver, M., P. J. Reimer, and R. W. Reimer

2020 CALIB 7.1 at http://calib.org, accessed February 6, 2020.

Suhm, D. A. and E. B. Jelks (editors)

1962 Handbook of Texas Archeology: Type Descriptions. Special Publication No. 1, Texas Archeological Society, and Bulletin No. 4, Texas Memorial Museum, Austin.

Walker, C. P. and D. P. McKinnon

2012 Exploring Prehistoric Caddo Communities through Archaeogeophysics. In The Archaeology of the Caddo, edited by T. K. Perttula and C. P. Walker, pp. 177-208. University of Nebraska Press, Lincoln.

Webb, C. H.

1963 The Smithport Landing Site: An Alto Focus Component in De Soto Parish, Louisiana. Bulletin of the Texas Archeological Society 32:143-187.

Webb, C. H. and R. R. McKinney

1975 Mounds Plantation (16CD12), Caddo Parish, Louisiana. Louisiana Archaeology 2:39-127.

Wells, T.

1998 Nail Chronology: The Use of Technologically Derived Features. Historical Archaeology 32(2):78-99. 
Wilson, D.

2012 Bioarchaeological Evidence of Subsistence Strategies among the East Texas Caddo. In The Archaeology of the Caddo, edited by T. K. Perttula and C. P. Walker, pp. 86-116. University of Nebraska Press, Lincoln.

Wilson, D. and T. K. Perttula

2013 Reconstructing the Diet of the Caddo through Stable Isotopes. American Antiquity 78(4):702-723. 


\section{Appendix 1, Shovel Test Descriptions}

ST No.

\section{Description}

\section{South Sector}

1 0-10 cm, dark brown fine sandy loam plow zone; 10-64 cm, light brown fine sandy loam; 64$67+$, reddish-yellow clay

2 0-12 cm, dark brown fine sandy loam; 12-58 cm, light brown fine sandy loam; 58-61 cm+, reddish-yellow clay

3 0-10 cm, dark brown fine sandy loam; $10-55 \mathrm{~cm}$, light brown fine sandy loam; $55-58 \mathrm{~cm}+$, reddish-yellow clay

4 0-12 cm, dark brown fine sandy loam plow zone; 12-57 cm, light brown fine sandy loam; 57-60 $\mathrm{cm}+$, strong brown clay

5 0-10 cm, dark brown fine sandy loam plow zone; 10-62 cm, light brown fine sandy loam; 62-65 $\mathrm{cm}+$, strong brown clay

6 0-14 cm, dark brown fine sandy loam plow zone; 14-72 cm, light brown fine sandy loam; 72-75 $\mathrm{cm}+$, strong brown clay

9 0-14 cm, dark brown fine sandy loam; $14-90 \mathrm{~cm}$, strong brown fine sandy loam; 90-93 cm+, brown clay

10 0-15 cm, dark brown fine sandy loam; $15-63 \mathrm{~cm}$, light brown fine sandy loam; 63-67 cm+, strong brown clay

11 0-14 cm, dark brown fine sandy loam; $14-52 \mathrm{~cm}$, light brown fine sandy loam; $52-55 \mathrm{~cm}+$, strong brown clay

12 0-16 cm, dark brown fine sandy loam; $16-63 \mathrm{~cm}$, light brown fine sandy loam; 63-66 cm+, strong brown clay

16 0-56 cm, strong brown fine sandy loam; 56-60 cm+, reddish-yellow clay

17 0-43 cm, strong brown fine sandy loam; 43-47 cm+, reddish-yellow clay

18 0-56 cm, strong brown fine sandy loam; 56-60 cm+, reddish-yellow clay

19 0-15 cm, brown fine sandy loam plow zone; $15-50 \mathrm{~cm}$, strong brown fine sandy loam; 50-54 $\mathrm{cm}+$, reddish-yellow clay

20 0-13 cm, brown fine sandy loam plow zone; $13-57 \mathrm{~cm}$, strong brown fine sandy loam; 57-60 $\mathrm{cm}+$, reddish-yellow clay 
21 0-12 cm, brown fine sandy loam plow zone; 12-60 cm, strong brown fine sandy loam; 60-64 $\mathrm{cm}+$, reddish-yellow clay

22 0-16 cm, brown fine sandy loam plow zone; $16-46 \mathrm{~cm}$, strong brown fine sandy loam; 46-50 $\mathrm{cm}+$, reddish-yellow clay

23 0-10 cm, brown fine sandy loam plow zone; $10-80 \mathrm{~cm}$, strong brown fine sandy loam; 80-83 $\mathrm{cm}+$, reddish-yellow clay

24 0-12 cm, dark brown fine sandy loam; 12-63 cm, strong brown fine sandy loam; 63-67 cm+, strong brown clay

25 0-14 cm, dark brown fine sandy loam plow zone; $14-70 \mathrm{~cm}$, strong brown fine sandy loam; 70$73 \mathrm{~cm}+$, strong brown clay

26 0-43 cm, strong brown fine sandy loam; 43-46 cm+, strong brown clay

27 0-13 cm, dark brown fine sandy loam plow zone; $13-50 \mathrm{~cm}$, strong brown fine sandy loam; 50$52 \mathrm{~cm}+$, strong brown clay

30 0-18 cm, dark brown fine sandy loam plow zone; $18-38 \mathrm{~cm}$, reddish-yellow fine sandy loam; 39$42 \mathrm{~cm}+$, yellowish-red clay

31 0-43 cm, strong brown fine sandy loam; 43-46 cm+, yellowish-red clay

32 0-41 cm, strong brown fine sandy loam; 41-44 cm+, yellowish-red clay

33 0-12 cm, dark brown fine sandy loam plow zone; $12-58 \mathrm{~cm}$, strong brown fine sandy loam; 58$62 \mathrm{~cm}+$, reddish-yellow clay

34 0-15 cm, dark brown fine sandy loam plow zone; $15-43 \mathrm{~cm}$, strong brown fine sandy loam; 43$46 \mathrm{~cm}+$, reddish-yellow clay

35 0-15 cm, dark brown fine sandy loam plow zone; $15-56 \mathrm{~cm}$, strong brown fine sandy loam; 56$60 \mathrm{~cm}+$, reddish-yellow clay

36 0-15 cm, dark brown fine sandy loam plow zone; $15-75 \mathrm{~cm}$, strong brown fine sandy loam; 75$78 \mathrm{~cm}+$, reddish-yellow clay

37 0-14 cm, dark brown fine sandy loam; 14-30 cm, yellow fine sandy loam; 30-66 cm, brownishyellow fine sandy loam; 66-70 $\mathrm{cm}+$, strong brown clay

38 0-12 cm, dark brown fine sandy loam; 12-44 cm, strong brown fine sandy loam; $44-47 \mathrm{~cm}+$, strong brown clay

39 0-12 cm, brown fine sandy loam; $12-45 \mathrm{~cm}$, strong brown fine sandy loam; 45-47 cm+, strong brown clay 
40 0-15 cm, dark brown fine sandy loam; $15-33 \mathrm{~cm}$, strong brown fine sandy loam; 33-36 cm+, strong brown clay

41 0-12 cm, dark brown fine sandy loam; $12-55 \mathrm{~cm}$, strong brown fine sandy loam; 55-60 cm+, strong brown clay

42 0-14 cm, dark brown fine sandy loam; $14-63 \mathrm{~cm}$, strong brown fine sandy loam; $60-66 \mathrm{~cm}+$, strong brown clay

43 0-13 cm, dark brown fine sandy loam; 13-72 cm, strong brown fine sandy loam; 72-80 cm+, strong brown clay

44 0-12 cm, dark brown fine sandy loam; $12-60 \mathrm{~cm}$, strong brown fine sandy loam; 60-63 cm+, strong brown clay

45 0-14 cm, dark brown fine sandy loam; $14-38 \mathrm{~cm}$, strong brown fine sandy loam; $38-42 \mathrm{~cm}+$, strong brown clay

46 0-15 cm, dark brown fine sandy loam; $15-18 \mathrm{~cm}+$, strong brown clay

47 0-14 cm, dark brown fine sandy loam; $14-36 \mathrm{~cm}$, strong brown fine sandy loam; 36-39 cm+, strong brown clay

48 0-12 cm, dark brown fine sandy loam; $12-43 \mathrm{~cm}$, strong brown fine sandy loam; $43-46 \mathrm{~cm}+$, strong brown clay

49 0-12 cm, dark brown fine sandy loam; $12-48 \mathrm{~cm}$, strong brown fine sandy loam; 48-52 cm+, strong brown clay

50 0-14 cm, dark brown fine sandy loam; $14-58 \mathrm{~cm}$, light yellowish-brown fine sandy loam; 58-62 $\mathrm{cm}+$, yellowish-brown clay

51 0-57 cm, brown fine sandy loam; $57-60 \mathrm{~cm}+$, strong brown clay

52 0-63 cm, brown fine sandy loam; 63-66 cm+, strong brown clay

53 0-10 cm, dark gray fine sandy loam plow zone; $10-53 \mathrm{~cm}$, light gray fine sandy loam; 53-56 $\mathrm{cm}+$, pink clay

54 0-12 cm, dark brown fine sandy loam plow zone; $12-42 \mathrm{~cm}$, strong brown fine sandy loam; 42$45 \mathrm{~cm}+$, strong brown clay

56 0-12 cm, dark brown fine sandy loam plow zone; $12-52 \mathrm{~cm}$, light brown fine sandy loam; 52-55 $\mathrm{cm}+$, strong brown clay

57 0-8 cm, dark gray fine sandy loam plow zone; $8-38 \mathrm{~cm}$, light gray fine sandy loam; $38-42 \mathrm{~cm}+$, mottled pink and strong brown clay 
100 0-10 cm, dark brown fine sandy loam plow zone; $10-55 \mathrm{~cm}$, light brown fine sandy loam; 55-58 $\mathrm{cm}+$, strong brown clay

101 0-10 cm, dark brown fine sandy loam plow zone; 10-47 cm, light brown fine sandy loam; 47-50 $\mathrm{cm}+$, strong brown clay

102 0-13 cm, dark brown fine sandy loam plow zone; $13-60 \mathrm{~cm}$, light brown fine sandy loam; 60-63 $\mathrm{cm}+$, strong brown clay

103 0-12 cm, dark brown fine sandy loam plow zone; $12-42 \mathrm{~cm}$, light brown fine sandy loam; 42-45 $\mathrm{cm}+$, strong brown clay

104 0-24 cm, brown fine sandy loam; 24-35 cm, very dark gray fine sandy loam; 35-38 cm+, strong brown clay

105 0-47 cm, strong brown fine sandy loam; 47-50 cm+, strong brown clay

106 0-62 cm, light brown fine sandy loam; 62-65 cm+, strong brown clay

107 0-58 cm, light brown fine sandy loam; 58-60 cm+, strong brown clay

108 0-52 cm, light brown fine sandy loam; $52-55 \mathrm{~cm}+$, strong brown clay

109 0-66 cm, light brown fine sandy loam; 66-70 cm+, strong brown clay

110 0-62 cm, light brown fine sandy loam; 62-65 cm+, strong brown clay

111 0-63 cm, light brown fine sandy loam; 63-66 cm+, strong brown clay

112 0-75 cm, light brown fine sandy loam; $75-78 \mathrm{~cm}+$, strong brown clay

113 0-63 cm, light brown fine sandy loam; 63-66 cm+, strong brown clay

114 0-54 cm, light brown fine sandy loam; $54-57 \mathrm{~cm}+$, strong brown clay

115 0-10 cm, dark brown fine sandy loam plow zone; 10-47 cm, strong brown fine sandy loam; 47$50 \mathrm{~cm}+$, strong brown clay

116 0-74 cm, light brown fine sandy loam; 74-77 cm+, strong brown clay

117 0-12 cm, dark brown fine sandy loam plow zone; $12-58 \mathrm{~cm}$, light brown fine sandy loam; $58-61$ $\mathrm{cm}+$, strong brown clay

118 0-76 cm, light brown fine sandy loam; 76-80 cm+, strong brown clay

119 0-57 cm, light brown fine sandy loam; 57-60 cm+, strong brown clay

120 0-76 cm, light brown fine sandy loam; 76-80 cm+, strong brown clay 
121 0-62 cm, light brown fine sandy loam; 62-65 cm+, strong brown clay

122 0-63 cm, light brown fine sandy loam; 63-66 cm+, strong brown clay

$1230-52 \mathrm{~cm}$, light brown fine sandy loam; $52-55 \mathrm{~cm}+$, strong brown clay

124 0-63 cm, light brown fine sandy loam; 63-66 cm+, strong brown clay

125 0-14 cm, dark brown fine sandy loam plow zone; 14-66 cm, light brown fine sandy loam; 66-70 $\mathrm{cm}+$, strong brown clay

126 0-71 cm, light brown fine sandy loam; 71-75 cm+, strong brown clay

$1270-52 \mathrm{~cm}$, light brown fine sandy loam; $52-55 \mathrm{~cm}+$, strong brown clay

128 0-58 cm, light brown fine sandy loam; 58-62 cm+, strong brown clay

129 0-64 cm, light brown fine sandy loam; 64-68 cm+, strong brown clay

130 0-12 cm, dark brown fine sandy loam plow zone; $12-78 \mathrm{~cm}$, light brown fine sandy loam; 78-82 $\mathrm{cm}+$, strong brown clay

131 0-12 cm, dark brown fine sandy loam plow zone; $12-36 \mathrm{~cm}$, light brown fine sandy loam; 36-40 $\mathrm{cm}+$, strong brown clay

132 0-53 cm, dark gray fine sandy loam; $53-57 \mathrm{~cm}+$, grayish-brown clay

133 0-8 cm, dark brown fine sandy loam; 8-36 cm, light brown fine sandy loam; 36-40 cm+, strong brown clay

134 0-10 cm, dark brown fine sandy loam plow zone; 10-41 cm, light brown fine sandy loam; 41-45 $\mathrm{cm}+$, strong brown clay

135 0-51 cm, dark gray fine sandy loam; $51-55 \mathrm{~cm}+$, grayish-brown clay

136 0-61 cm, brown fine sandy loam; 61-65 cm+, strong brown clay

137 0-74 cm, light brown fine sandy loam; 74-78 cm+, strong brown clay

138 0-64 cm, light brown fine sandy loam; 64-68 cm+, strong brown clay

139 0-51 cm, light brown fine sandy loam; $51-55 \mathrm{~cm}+$, strong brown clay

140 0-36 cm, light brown fine sandy loam; 36-40 cm+, strong brown clay

141 0-61 cm, light brown fine sandy loam; 61-65 cm+, strong brown clay

142 0-57 cm, light brown fine sandy loam; 57-60 cm+, strong brown clay 
143 0-58 cm, light brown fine sandy loam; 58-60 cm+, strong brown clay

144 0-52 cm, light brown fine sandy loam; 52-55 cm+, strong brown clay

145 0-66 cm, light brown fine sandy loam; 66-70 cm+, strong brown clay

146 0-70 cm, light brown fine sandy loam; 70-75 cm+, strong brown clay

147 0-72 cm, light brown fine sandy loam; $72-75 \mathrm{~cm}+$, strong brown clay

148 0-8 cm, dark brown fine sandy loam plow zone; 8-32 cm, light brown fine sandy loam; 32-35 $\mathrm{cm}+$, strong brown clay

149 0-11 cm, dark brown fine sandy loam plow zone; 11-47 cm, light brown fine sandy loam; 47-50 $\mathrm{cm}+$, strong brown clay

150 0-46 cm, light brown fine sandy loam; $46-50 \mathrm{~cm}+$, strong brown clay

151 0-43 cm, light brown fine sandy loam; 43-46 cm+, strong brown clay

152 0-41 cm, light brown fine sandy loam; 41-45 cm+, strong brown clay

\section{North Sector}

7 0-10 cm, dark brown fine sandy loam plow zone; $10-80 \mathrm{~cm}$, strong brown fine sandy loam; 80$83 \mathrm{~cm}+$, reddish-yellow clay

8 0-10 cm, dark brown fine sandy loam plow zone; 10-100 $\mathrm{cm}+$, strong brown fine sandy loam

13 0-96 cm, strong brown fine sandy loam; 96-100 cm+, reddish-yellow clay

14 0-71 cm, strong brown fine sandy loam; 71-75 cm+, reddish-yellow clay

15 0-67 cm, strong brown fine sandy loam; 67-70 cm+, reddish-yellow clay

28 0-12 cm, dark brown fine sandy loam plow zone; $12-55 \mathrm{~cm}$, strong brown fine sandy loam; 55$58 \mathrm{~cm}+$, reddish-yellow clay

29 0-15 cm, dark brown fine sandy loam plow zone; $15-100 \mathrm{~cm}+$, strong brown fine sandy loam

55 0-14 cm, dark brown fine sandy loam plow zone; $14-83 \mathrm{~cm}$, strong brown fine sandy loam; 83$86 \mathrm{~cm}+$, strong brown clay

153 0-8 cm, dark brown fine sandy loam; 8-36 cm, strong brown fine sandy loam; 36-40 cm+, reddish-yellow clay

154 0-10 cm, dark brown fine sandy loam plow zone; 10-34 cm, strong brown fine sandy loam; 34$38 \mathrm{~cm}+$, reddish-yellow clay 
155 0-11 cm, dark brown fine sandy loam plow zone; $11-41 \mathrm{~cm}$, strong brown fine sandy loam; 41$45 \mathrm{~cm}+$, reddish-yellow clay

156 0-8 cm, dark brown fine sandy loam plow zone; 8-57 cm+, strong brown fine sandy loam; water table hit at $57 \mathrm{~cm}$ bs

157 0-8 cm, dark brown fine sandy loam plow zone; 8-30 cm+, strong brown fine sandy loam; large roots at $30 \mathrm{~cm}$ bs

158 0-12 cm, dark brown fine sandy loam plow zone; $12-78 \mathrm{~cm}$, strong brown fine sandy loam; 78$82 \mathrm{~cm}+$, reddish-yellow clay

159 0-8 cm, dark brown fine sandy loam plow zone; 8-46 cm, strong brown fine sandy loam; 46-50 $\mathrm{cm}+$, reddish-yellow clay

160 0-10 cm, dark brown fine sandy loam plow zone; 10-48 cm, strong brown fine sandy loam; 48$62 \mathrm{~cm}+$, reddish-yellow clay

161 0-56 cm, strong brown fine sandy loam; 56-60 cm+, reddish-yellow clay

162 0-8 cm, dark brown fine sandy loam plow zone; $8-48 \mathrm{~cm}$, strong brown fine sandy loam; 48-52 $\mathrm{cm}+$, reddish-yellow clay

163 0-10 cm, dark brown fine sandy loam plow zone; 10-47 cm, strong brown fine sandy loam; 47$50 \mathrm{~cm}+$, reddish-yellow clay

164 0-64 cm, strong brown fine sandy loam; 64-68 cm+, reddish-yellow clay

165 0-53 cm, strong brown fine sandy loam; 53-57 cm+, reddish-yellow clay

166 0-96 cm, strong brown fine sandy loam; 96-100 cm+, reddish-yellow clay

167 0-72 cm, strong brown fine sandy loam; 72-75 cm+, reddish-yellow clay

168 0-78 cm, strong brown fine sandy loam; 78-83 cm+, reddish-yellow clay

169 0-82 cm, strong brown fine sandy loam; 82-85 cm+, reddish-yellow clay

170 0-82 cm, strong brown fine sandy loam; 82-85 cm+, reddish-yellow clay

171 0-93 cm, strong brown fine sandy loam; 93-100 cm+, reddish-yellow clay

172 0-84 cm, strong brown fine sandy loam; 84-90 cm+, reddish-yellow clay

$1730-76 \mathrm{~cm}$, strong brown fine sandy loam; 76-80 cm+, reddish-yellow clay

174 0-96 cm, strong brown fine sandy loam; 96-100 cm+, reddish-yellow clay

175 0-100 $\mathrm{cm}+$, strong brown fine sandy loam 
176 0-100 $\mathrm{cm}+$, strong brown fine sandy loam

177 0-65 cm, strong brown fine sandy loam; 65-70 cm+, reddish-yellow clay

178 0-67 cm, strong brown fine sandy loam; 67-70 cm+, reddish-yellow clay 